Linköping University Medical Dissertations No. 1615

\title{
Läkare, lärande och interaktion i hälso-och sjukvårdspraktiker
}

\author{
Karin Thörne
}

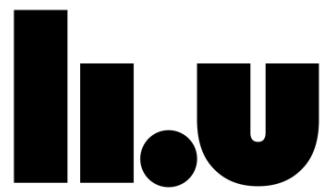

LINKÖPINGS UNIVERSITET

Department of Medical and Health Sciences

Linköping University, Sweden

Linköping 2018 
@Karin Thörne, 2018

Design omslagsbild: Petter Thörne, Karin Thörne. En visualisering av sammankopplingar mellan olika former av praktiker och patienter.

Published articles have been reprinted with the permission of the copyright holder.

Printed in Sweden by LiU-Tryck, Linköping, Sweden, 2018

ISBN 978-91-7685-336-8

ISSNo345-0082 
Till mina föräldrar Marianne och Palle som gav mig livet och hållningen att leva det med lärande som spännande och livslångt manus.

They change the world by their changed being they change the world by their learning and its effects.

About children (Kemmis 2014 p 88) 



\section{INNEHÅLLSFÖRTECKNING}

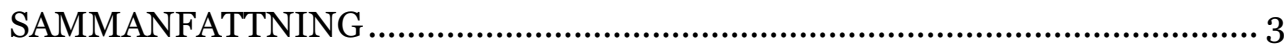

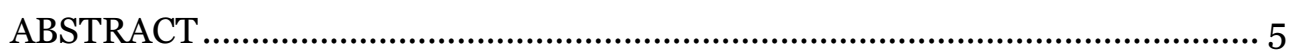

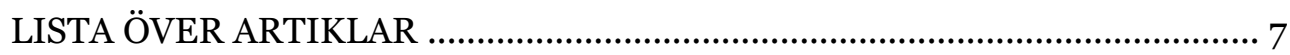

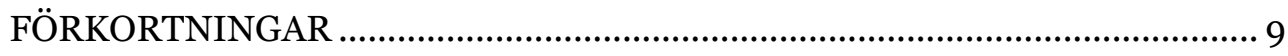

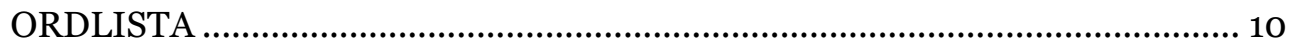

TACK

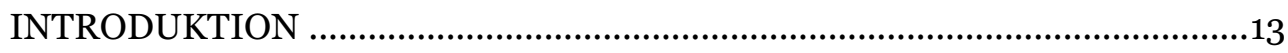

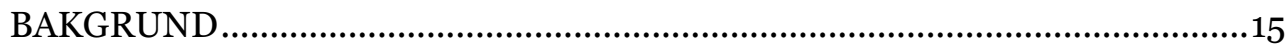

Hälso- och sjukvård i förändring ...............................................................15

Det dagliga hälso- och sjukvårdsarbetet........................................................17

Läkares lärande och interaktion i hälso- och sjukvårdsarbete ...................20

Lärande i professionella praktiker................................................................. 23

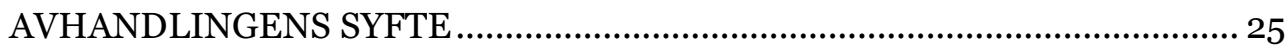

Övergripande forskningfrågor ................................................................... 25

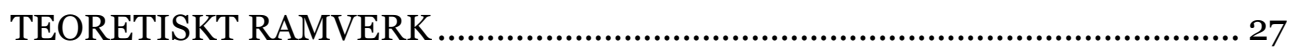

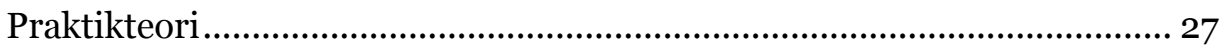

Sociokulturellt perspektiv ......................................................................... 29

Sociomateriella perspektiv ............................................................................ 30

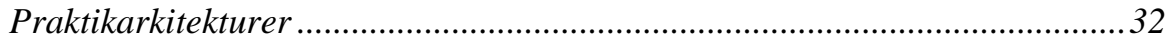

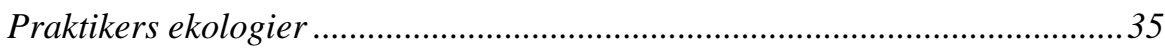

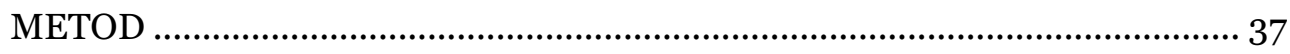

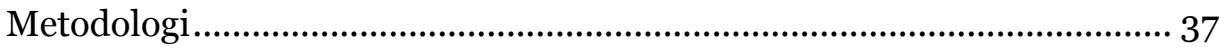

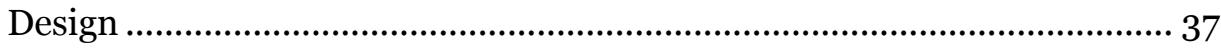

Metod studie A …………………............................................................ 38

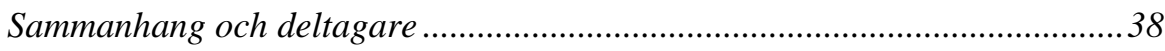

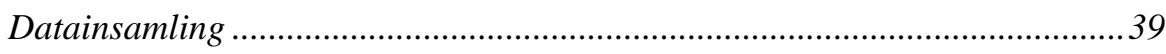

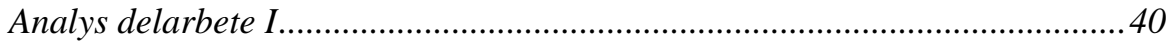

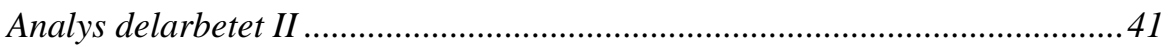

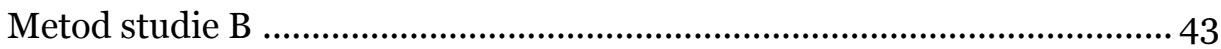


Interaktiv forskningansats med fältstudiedesign .......................................43

Sammanhang och deltagare ....................................................................... 44

Datainsamling $i$ den interaktiva processen ..............................................45

Analyser i den interaktiva processen ...........................................................4 47

Avslutande analys delarbete III.................................................................. 48

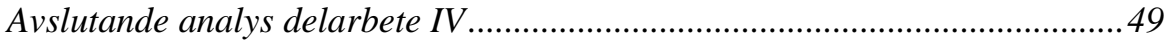

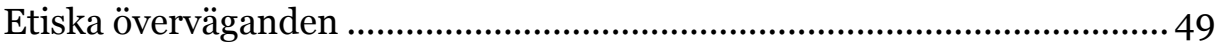

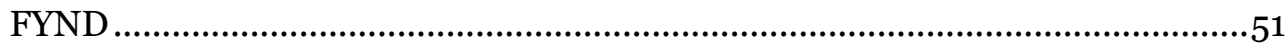

Pedagogiska processer i hälso- och sjukvården: En utforskande studie om pedagogiskt arbete med patienter och närstående (I) .......................51

Dynamiken i läkares lärande och stöd till andras lärande (II) .................. 52 Samskapat interprofessionellt rondarbete: Att designa rum för partnerskap med patienter (III) .................................................. 54

Lärande i arbetet: Ekologiska sammankopplinga i underläkares hälsooch sjukvårdspraktiker (IV) ...................................................... 56

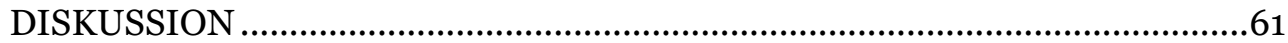

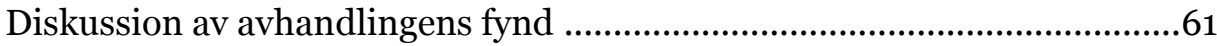

Begränsningar och brister för konstruktivt lärande ..................................61

Patienter, närstående och lärande .............................................................65

Mångdimensionellt lärande

i specifika hälso- och sjukvårdspraktiker..................................................6 68

Läkare och dynamiken i lärande i och mellan olika praktiker ....................... 70

Underläkares lärandepraktik $i$ hälso- och sjukvårdspraktiker ....................... 77

Lärande, förändringar

och hälso- och sjukvårdspraktikers utveckling

Diskussion om trovärdighet och kvalitet avhandlingens ....................8 84

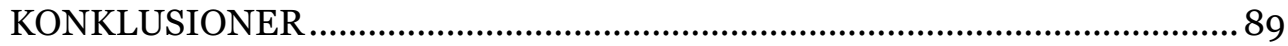

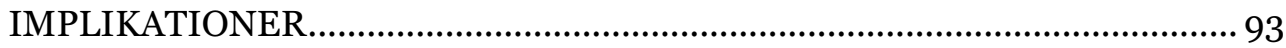

Lärande och interaktion i hälso- och sjukvårdpraktiker.............................. 93

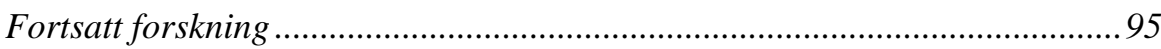

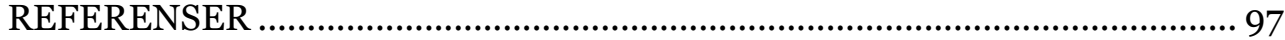




\section{SAMMANFATTNING}

Bakgrund: Komplexiteten i hälso- och sjukvården blir kontinuerligt större, liksom möjligheterna till diagnostik och behandling. Samtidigt pressas hälso- och sjukvården av förändringar i demografier och sjukdomspanoraman, olika uttryck för globalisering och tillämpning av nya teknologier. Ett omfattande antal olika professioner förväntas genomföra och utveckla det dagliga arbetet med ännu mer involvering av patienter. Vi behöver mer kunskap om hur lärande sker och hur det underlättas och utvecklas i dagligt hälso- och sjukvårdsarbete för att kunna möta förändringar och utmaningar.

Syfte: Avhandlingens övergripande syfte är att fördjupa kunskap och förståelse om pedagogiska processer och lärande i hälso- och sjukvårdspraktiker, med särskilt fokus på läkare.

Metoder: Intervjustudier och fältstudie med interaktiv forskningsansats gav data med både bredd och djup från autentiskt hälso- och sjukvårdsarbete. I pågående hälso- och sjukvårdsarbete studerades läkare, vårdgivare i andra professioner, patienter, redskap som användes och praktikens rumsliga utformning. Data analyserades genom både kulturella och sociomateriella praktikteoretiska linser, vilket möjliggjorde att flera dimensioner av lärande och interaktion i hälso- och sjukvårdspraktiker kunde spåras.

Fynd: I arbetet med patienter agerade läkare och andra professioner pedagogiskt med eller utan intentioner, i pedagogiska processer som bestod av att avläsa-färdrikta-lärstödja. Den pedagogiska dimensionen av arbetet var inte synliggjord eller diskuterad i relation till patientarbetet. Dynamiskt inbäddat i arbetet lärde och stöttade läkare också yngre läkares och andra vårdgivares lärande. Läkarnas mobilitet $\mathrm{i}$ olika vårdsammanhang, såväl som ansvarsfördelning och delande av olika perspektiv, hade betydelse för vilket lärande som uppstod.

Genom att betrakta specifika vårdsammanhang som hälso- och sjukvårdspraktiker under utövning, framträdde vid studiet av en 
rondmodell både samskapande lärande ronder och operativa ronder med begränsat lärande. Det framträdde genom sättet som deltagande personer, rumsliga och materiella förhållande samspelade på, som ömsesidigt utbyte respektive separata individuella arbetsprocesser. Samspelet mellan hälso- och sjukvårdspraktikers arrangemang (praktikarkitekturer) och genomförande snarare begränsade än underlättade underläkares lärandepraktiker. Underläkarnas arbete hade inte kontinuitet, koherens eller progression för att bredden av kunnande i medicinsk praktiskt arbete skulle kunna utvecklas bra.

Implikationer: Att förstå och synliggöra lärande i hälso- och sjukvårdens dagliga arbete genom att gemensamt prata om pedagogiska dimensioner $\mathrm{i}$ det arbete som pågår, kan utveckla lärande och lärstödjande ageranden. Samskapande lärande hälso- och sjukvårdspraktiker där alla deltagande gruppers behov och uppdrag medräknas, har implikationer på underläkares kompetensutveckling, studenters lärande, patienters involvering i sin vård och interprofessionellt och interdisciplinärt samarbete. Det ger också ledare möjlighet att knyta arbete med förbättringar av vårdens kvalitetet och säkerhet till dagligt vårdarbete. 


\section{ABSTRACT}

Background: The level of complexity within healthcare services is continually increasing. These services are put under pressure by changing demographics and associated illness profiles, the influence of globalization, and the introduction of new technologies. Physicians are expected to perform and develop their daily work in cooperation with other healthcare professionals and in association with increasing levels of patient involvement. In such a changing and challenging healthcare environment, more knowledge is needed about how learning takes place and how learning can be facilitated and developed in the daily provision of healthcare services.

Aim: The overarching aim of this dissertation is to deepen our knowledge and understanding of the pedagogic processes and the learning that takes place in healthcare practices, with particular focus on physicians' learning.

Methods: The research methodology employed in this dissertation includes interviews and field studies that used an interactive research approach. Authentic healthcare practices, including physicians, other care providers, patients, clinical tools in use, and the spatial arrangements within which the healthcare practices were performed were studied. The data that was collected was analyzed from a practice-theory perspective, thus allowing the researcher to identify and describe several dimensions of learning and interaction in healthcare practices.

Results: The pedagogic processes that were identified in the physicians' and the other healthcare practitioners' daily work with their patients can be described as read-guide-learning support. The pedagogic dimension of this work was not immediately revealed nor was it overtly articulated. The physicians dynamically, by themselves, taught and supported the junior physicians and other healthcare providers' learning. The physicians' mobility in a variety of healthcare contexts was of relevance to the learning that took place. By viewing specific healthcare contexts as performing health care practices during the study, a rounds work emerged which included both (i) co-produced learning rounds and (ii) operative rounds which gave rise to limited learning. The interaction 
between arrangements in healthcare practices, 'practice architectures', and the performance of the healthcare practices actually limited the junior physicians' learning.

Implications of the study: A proper understanding of the learning that takes place during the daily work in the provision of healthcare - by revealing and examining the pedagogic dimensions of the work that is done - can contribute to the development of learning and learning support mechanisms. Co-produced learning healthcare practices, where each participant's needs and contributions are taken into account, have direct implications for professional development initiatives and learning, for patient involvement in their healthcare arrangements, and for interprofessional and inter-disciplinary cooperation. Such practices also provide responsible leaders and decision-makers with the opportunity to tie in healthcare quality assurance work with the daily work that is performed by healthcare practitioners in the field. 


\section{LISTA ÖVER ARTIKLAR}

I. Hult, H., Lindblad Fridh M., Lindh Falk A., Thörne K. (2009). Pedagogical processes in Health Care: An Exploratory Study of Pedagogic Work with Patients and Next of Kin. Education for Health.22(3), 199.

II. Thörne, K., Hult, H., Andersson Gäre, B., Abrandt Dahlgren, M. (2014). The Dynamics of Physicians' Learning and Support of Others' Learning. Professions \& Professionalism. 4(1).

III. Thörne, K., Andersson-Gäre, B., Hult, H., \& Abrandt-Dahlgren, M. (2017). Co-Producing Interprofessional Round Work: Designing Spaces for Patient Partnership. Quality Management in Healthcare. 26(2),70-82. dio: 10.1097/qmh.0000000000000133

IV. Thörne, K., Hult, H., Andersson Gäre, B., Abrandt Dahlgren, M. Learning at Work: Junior physicians in ecologies of health care practices. (under revision april, 2018). 


\section{FÖRKORTNINGAR}

AT allmäntjänstgöring, AT-läkare

ST specialiseringstjänstgöring, ST-läkare

VIL verksamhets integrerat lärande

VFU verksamhetsförlagd utbildning

\section{FIGURER OCH TABELLER}

\section{Figurer}

Figur 1. Länkade mål i kvalitets- och förbättringsarbete..

Figur 2. Praktiker formas av "sägande", "görande" och "relaterande" som hänger ihop i projekt

Figur 3. Medierna och utrymmena där "sägande", "görandet" och "relaterande"t existerar .33

Figur 4. En teori om lärande i hälso- och sjukvårdens $(\mathrm{HoS})$ praktiker som bygger på Kemmis teori om utbildning och praktikarkitekturer. 34

Figur 5. Schematisk illustration av hur patienters och olika professionspraktikers sammankopplingar framträder under en arbetsdag.

\section{Tabeller}

Tabell 1. Forskningsfenomen, studiedesign, informanter och datakällor. .............36

Tabell 2. Summering av metoder i de två delarbetena från studie A .....................38

Tabell 3. Exempel från analysprocessen i delarbete II.........................................40

Tabell 4.Metod, deltagare, data och analyser i den interaktiva ansatsen med

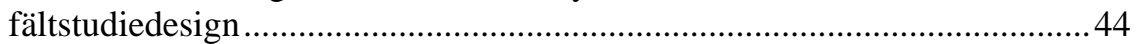

Tabell 5. Summering av metoderna i de två delarbetena i Studie B .....................46

Formgivna i samarbete med Petter Thörne och *Johan Avby Werner 


\section{ORDLISTA}

\begin{tabular}{|c|c|}
\hline diskurser & $\begin{array}{l}\text { helhet av sammanhängande uttryck, utsagor och } \\
\text { begrepp }\end{array}$ \\
\hline kliniska mikrosystem & $\begin{array}{l}\text { en grupp professionella som regelbundet arbetar } \\
\text { tillsammans och ger service till en avgränsad patient- } \\
\text { population och som har gemensamma mål, } \\
\text { processer, } \\
\text { resultatuppföljning }\end{array}$ \\
\hline intersubjektiva rum & rum/utrymme som ligger mellan människor \\
\hline $\begin{array}{l}\text { extraindividuella } \\
\text { förhållanden }\end{array}$ & $\begin{array}{l}\text { förhållanden som existerar utöver varje enskild } \\
\text { agerande person }\end{array}$ \\
\hline $\begin{array}{l}\text { praktik, Kemmis och } \\
\text { Mahon (2017) } \\
\text { praktikteoretiska } \\
\text { ramverk }\end{array}$ & $\begin{array}{l}\text { socialt etablerade samverkande mänskliga aktiviteter } \\
\text { som involverar redskap, förståelse (sägande), sätt att } \\
\text { agera (görande) och sätt att relatera till varandra om } \\
\text { omvärlden (relaterande) som hänger ihop på ett } \\
\text { karakteristiskt sätt i projekt }\end{array}$ \\
\hline praktikarkitekturer & $\begin{array}{l}\text { en praktiks praktikarkitekturer är specifika } \\
\text { kulturellt-diskursiva, ekonomiskt-materiella och } \\
\text { socialt-politiska arrangemang som hänger samman i } \\
\text { projekt }\end{array}$ \\
\hline projekt & $\begin{array}{l}\text { består av 1) intention som motiverar en praktik, 2) } \\
\text { agerande i en praktik, och } 3 \text { ) slutresultat av en } \\
\text { praktik }\end{array}$ \\
\hline prefigurera & $\begin{array}{l}\text { avgränsade förutsättningar som formar, underlättar, } \\
\text { skapar eller begränsar vad som utförs i en praktik }\end{array}$ \\
\hline $\begin{array}{l}\text { kulturellt-diskursiva } \\
\text { arrangemang }\end{array}$ & $\begin{array}{l}\text { prefigurerar och möjliggör det specifika sägandet i en } \\
\text { praktik genom att möjliggöra eller begränsa vad som } \\
\text { är relevant att säga (tänka) om och i en praktik }\end{array}$ \\
\hline $\begin{array}{l}\text { materiellt-ekonomiska } \\
\text { arrangemang }\end{array}$ & $\begin{array}{l}\text { formar görandet i en praktik genom att påverka vad, } \\
\text { när, hur och av vem något görs }\end{array}$ \\
\hline $\begin{array}{l}\text { socialt-politiska } \\
\text { arrangemang }\end{array}$ & $\begin{array}{l}\text { formar personers sätt att relatera till varandra och } \\
\text { icke- mänskliga föremål }\end{array}$ \\
\hline praktikers ekologier & $\begin{array}{l}\text { empiriskt identifierade kopplingar och relationer } \\
\text { mellan praktiker i ett sammanhang }\end{array}$ \\
\hline
\end{tabular}




\section{TACK}

$\mathrm{Nu}$, årets första dag med sommarkänslan, fågelsång, sol, över 20 grader varmt och vårblommor som fullkomligt exploderar, söndagen den 8 april 2018 när jag skriver detta tack är det påtagligt att mina doktorandstudier går mot sitt slut. För en vecka sedan var det full vinter i södra Sverige och Leif, min make, åkte skidor på Komosse så sent som igår. Det har varit en lång vinter som ramat in och underlättat mitt slutliga skrivande, efter år av utvecklande och hårt arbete. En forskningsprocess som skapat förändrade perspektiv, utvecklande relationer, vidgade möjligheter och inte minst fascination över livet. Jag fylls med glädje och tacksamhet!

Först vill jag tacka dem som deltagit $\mathrm{i}$ de studier som ingår $\mathrm{i}$ avhandlingen, liksom deras chefer. Det är deras beredvillighet att bjuda på sina berättelser, arbetsvardag och verksamheter som möjliggjort avhandlingen.

Avhandlingen är skriven vid Institutionen för medicin och hälsa, Medicinska fakulteten Linköpings Universitet. Genom handledarna och projektet Bridging the Gaps har mina forskningsstudier förankring i Jönköping Academy, Jönköping University. Bridging the Gaps är ett forskningsprogram finansierat av Vinnvård. Forskningsstudierna har framförallt finansierats av min arbetsgivare Futurum - akademin för hälsa och vård, vars uppgift är att stödja genomförande och utveckling av verksamhetsnära forskning. Jag är djupt tacksam för att dessa sammanhang med alla skickliga människor gjort det möjligt för mig att fullfölja mina doktorandstudier.

Min huvudhandledare Madeleine Abrandt Dahlgren är den första personen som jag riktar ett varmt och ödmjukt tack till. Det sätt som du väglett mig genom dina inspirerande och djupa kunskaper, utmanande klarsynta diskussioner och tålmodigt återkopplande har gjort att jag kunnat hålla kursen i en vardag som också rymt mycket annat arbete. Den forskningspraktik inom Medicinsk pedagogik som utvecklats under din ledning har för mig varit mycket betydelsefull. Och inte minst den varma, humoristiska "Madde" som hela tiden ger plats för vardagslivet.

Nästan från början och nästan fram till slutet av mina doktorandstudier har Boel Andersson-Gäre varit min chef på Futurum, Region Jönköpings län och dessutom min bihandledare. Boel, du är möjligheterna och de kreativa lösningarna personifierad. Så många gånger har våra 
diskussioner spänt över konkret forskning, dagligt arbete och vårdens utmaningar, möjligheter och utveckling. Både dessa mötespunkter och det förtroende du gett mig i att balansera forskning, Futurumarbete, nationella och internationella nätverk har haft stor betydelse för mig. Det har möjliggjort förankring av forskningen i hälso- och sjukvården och konkreta sammanhang att tillämpa kunskaper jag utvecklat i forskningsprocessen. Tack!

Den som fångade in mig i den forskning som nu har lett fram till min doktorsexamen var Håkan Hult, min andre bihandledare. De första gemensamma mötena när du lotsade oss, tre kvinnor $\mathrm{i}$ tre vårdprofessioner, in i forskningens fascinerande sammanhang, lever starkt kvar hos mig. Tack för ditt stöd och din klokskap!

Forskargruppen i Medicinsk Pedagogik har varit ett viktigt nav, där jag tillsammans med er andra kunnat diskutera både min och andras forskning. Det har gett värdefulla tillskott i mina dataanalyser och mitt skrivande. Speciellt tack till mina doktorandkamrater, Annika, Karin och Liselott för alla tillfällen då vi brottats med våra teoretiska perspektiv.

Doktorandgruppen inom Bridging the Gaps vill jag också rikta ett tack till. Intensiva år med gemensamma kurser och förankring av forskningsprojekt i hälso- och sjukvården, gav mycket inspiration och glädje. Ett speciellt tack till Ann-Charlott för många kvällar vid vårt köksbord och till Annika för support på sluttampen.

Som pendlande doktorand har jag fått njuta gästfrihet hos tre härliga par Pia och Harald, Anette och Anders, Annika och Peter. Det har blivit många sköna pratkvällar över ett glas vin. Det har varit guld värt, tack!

Tack också till alla arbetskamrater på Futurum och i Region Jönköping som både varit uppmuntrande och haft tålamod med mitt uppdelade arbetsliv, Agneta särskilt som speciellt mot slutet fătt bära mycket.

Tack alla gamla och nya vänner som hjälpt mig att också fokusera på livets goda, vänskap, "matlagandet", naturen och söndagsreflektioner.

De avslutande innerliga tacken går självklart till min älskade make, Leif och våra barn underbara Petter, Anton och Anna med familjer. Tack för all den glädje och förtrogenhet ni ger i livet. Tack för er uppmuntran och tålmodighet, när forskandet svämmat ut och när jag varit närvarande men ändå inte.

Nu är det dags för det där alldeles extra! 


\section{INTRODUKTION}

Hälso- och sjukvårdens alla vårdgivare har till uppgift att för eller med varje patient skapa vård med hög kvalitet och säkerhet. Arbetet genomförs dagligen i en oändlig mängd hälso-och sjukvårdspraktiker. I varje sådan hälso- och sjukvårdpraktik (på kliniker, vårdcentraler, avdelningar, mottagningar) agerar och samverkar ett antal olika professioner med medicinska, omvårdande, rehabiliterande och vårdadministrativa kompetenser, när de möter patienter som har problem, funktionsnedsättningar och sjukdomar. Olika professioner är beroende av varandra i genomförandet av vården, samtidigt har läkare ofta uppgiften att bedöma och fatta slutgiltiga beslut i medicinskt komplexa eller svårbedömda situationer.

Trots att det finns och kontinuerligt utvecklas stora mängder betydelsefull kunskap inom hälso- och sjukvårdens kliniska områden når den ändå inte varje patient eller vårdgivare när de behöver den. Kunskap av värde för dem kan vara svårtillgänglig, felaktigt använd eller begränsad av hälso- och sjukvårdspraktikers sätt att organisera sig och använda sina resurser. Samtidigt genomförs. hela tiden insatser för att utveckla kvalitet, säkerhet och patientcentrering i vården. Mot bakgrund av den centrala roll läkare har i detta avseende är det av betydelse hur de bidrar till de fortlöpande förändringar som behövs.

I hälso- och sjukvårdspraktiker där vårdgivare möter patienter och tillämpar sitt kunnande sker också lärande. Lärande för vårdgivare som medför att de utvecklar genomförandet av vården med och för patienter, förstår och omsätter nya rön i dagligt arbete och modifierar hur de samverkar för att bidra till bättre och säkrare vård. Det innefattar patienters lärande och förståelse för att initierat kunna agera i sin vård, men också omvänt hur patienters perspektiv kan bidra till vårdgivares lärande. I dagligt hälso- och sjukvårdsarbete är lärande och pedagogiska aspekter oftast inte i fokus, än mindre strategiskt tillämpat.

Mot bakgrund av att i många år ha arbetat som klinisk läkare och med utbildning i vården, menar jag att vi genom att synliggöra och bättre förstå hur lärande i hälso- och sjukvårdspraktiker sker och kan utvecklas, făr potential att förändra sättet att samarbeta, involvera patienter och 
tillämpa flödet av ny kunskap. Detta är särskilt viktigt med tanke på de komplexa utmaningarna hälso- och sjukvården står inför. Synliggörande av lärande och pedagogiska processer kan i sin tur bidra till att möta de utmaningar som den komplexa hälso- och sjukvården ständigt står inför. 


\section{BAKGRUND}

\section{Hälso- och sjukvård i förändring}

I hälso- och sjukvården i Sverige och internationellt sker kontinuerligt förändringar och omfattande utveckling vilket medför tilltagande komplexitet. Komplexiteten kan kortfattat sammanfattas genom en uppräkning av ett antal förhållanden (SOU 2016:2). Den patientnära hälso- och sjukvården genomförs av ett stort antal professioner såsom inom medicin, omvårdnad, rehabilitering, diagnostik och vårdadministration.

De patientrelaterade vårdprocesserna sträcker sig ofta över flera medicinska discipliner inom samma eller mellan olika sjukvårdshuvudmän och gentemot andra sektorer och organisationer i samhället. Samverkan sker med organisationer och verksamheter som kommunal omsorg, socialtjänst, skolhälsovård, apoteksverksamhet och försäkringskassa m.fl. För att hantera komplexiteten behövs förändringar i och kunskap om samarbete interprofessionellt, interdisciplinärt och intersektoriellt (Frenk et al., 2010; SOU 2016:2).

Avancerad teknik och informationsteknologi utvecklas och skapar ständigt nya möjligheter och arbetssätt i det dagliga arbetet. Däri ingår att artificiell intelligens avancerar i hälso- och sjukvården och både ersätter och kompletterar arbetsätt i direkt patientarbete, informationsbearbetning och organisatoriska aspekter vårdarbetet (Hamet \& Tremblay, 2017). Vårdens professioner är beroende av och behöver samverka med experter inom olika teknologier såväl som logistik.

Komplexiteten i hälso- och sjukvården tilltar också genom dess globalisering, genom internationell kunskapsspridning, utbyte av vårdtjänster och behovet av samverkan i patienters vårdprocesser (Frenk et al., 2010). Migration har medfört att Sveriges befolkning har blivit alltmer multietnisk, vilket återspeglas både bland vårdtagare och bland vårdgivare. Den ökade bredden av vårdtagare har konsekvenser för hur vården genomförs. Samtidigt är allt fler inom medicin och vårdyrken utbildade i andra länder och deras integration i svensk hälso- och sjukvård kräver specifika insatser. Bland dem som erhöll läkarlegitimation i Sverige 2016 hade $50 \%$ genomfört sin grundutbildning utanför Sverige (Bastjänstgöring för läkare, 2017).

Andra demografiska förändringar, såsom en åldrande befolkning, fler multisjuka personer (Östgötakommissionen för folkhälsa: slutrapport, 2014) ökad psykisk ohälsa speciellt bland unga (Folkhälsans utveckling - 
årsrapport 2017) och förändrade sjukdomspanoraman som för infektionssjukdomar, utgör utmaningar som ställer krav på förändringar i hälso- och sjukvården. För att möta dessa och andra förändringar har svensk hälso- och sjukvård påbörjat en omställning från sjukhusvård till mer primärvård och annan närsjukvård. Enligt betänkandet Effektiv vård (SOU 2016:2) är svensk hälso- och sjukvård i internationella jämförelser välfungerande. Den har ändå organisatoriska, kompetensmässiga och kulturella utmaningar som behöver hanteras i hälso- och sjukvårdens dagliga arbete. Utmaningarna inkluderar förhållningssätt, värderingar och förmåga att i vården hantera kontinuerliga förändringar.

I kontinuerliga förändringar ingår kunskapsutveckling och tillämpning av ständigt nya medicinska rön och andra möjligheter som skapas genom forsknings- och utvecklingsarbete. Samtidigt visar forskning att den växande forskningsbaserade eller evidensbaserade kunskapen har begränsad påverkan på det dagliga hälso- och sjukvårdsarbetet (Greenhalgh, Raftery, Hanney, \& Glover, 2016). I svensk hälso- och sjukvård strävar man efter att underlätta så att alla patienter ska erhålla den vård som aktuell evidensbaserad kunskap förespråkar. Det sker exempelvis genom insatser på nationell nivå genom infrastrukturer för tillhandahållande av specifika kunskapsstöd för vårdgivare i relation till olika sjukdomstillstånd (SKL, 2017) samt vårdnära data och kvalitetsregister som följer och återkopplar vårdens resultat (Jacobsson, Lindahl, \& Nordin, 2015). Varje verksamhet rekommenderas att utgå från registerresultat för att göra jämförelser, lära av variationen och utveckla sina arbetsmetoder(Nyström et al., 2017). Batalden och Davidoff (P. Batalden \& Davidoff, 2007) menar att målen i kvalitets- och förbättringsarbete är länkade (fig.1). Kvalitetsförbättringar inkluderar

Figur 1. Länkade mål i kvalitets- och förbättringsarbete. Översatt från (Batalden \& Davidoff, 2007 s.2).

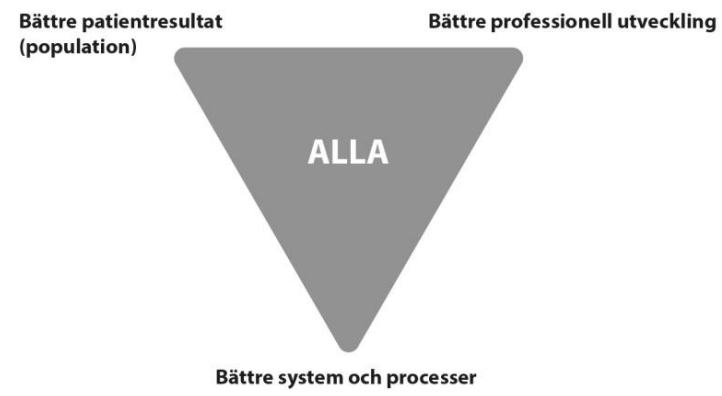


förändringar som resulterar i bättre patientresultat, bättre system och processer och bättre professionell utveckling (fig.1). De betonar vikten av att alla, även patienter, är engagerade för att genomföra förbättringar och skapa utveckling i hälso- och sjukvården på alla nivåer.

Den relativt nya patientlagen i Sverige (SFS 2014:821) om patienters involvering och delaktighet i sin egen vård och i vårdens utveckling, är långt ifrån generellt införd i det dagliga hälso- och sjukvårdsarbetet. Olika modeller såsom personcentrerad eller samskapande hälso- och sjukvård är under utveckling för att underlätta patienters delaktighet. I personcentrerad vård etableras partnerskap genom patientens berättelse. Detta utgör en grund för gemensamt beslutsfattande och dokumentation som hålls transparent för patienten (Ekman et al., 2011). Samskapande hälso- och sjukvård är ett vidare begrepp, översatt från det internationellt använda co-produced health care, som har sitt ursprung utanför hälsooch sjukvården och från början beskrev andra serviceinriktade verksamheter. Samskapande service innebar att givare och mottagare på individuell, grupp- eller kollektiv nivå aktivt bidrog i genomförandet av aktuell service (Brudney \& England, 1983). Ostrom vidareutvecklade samskapande service och definierade det som relationer mellan servicegivare och mottagare som tillsammans är beredda att förändras till säkrare, kunnigare och sundare personer eller verksamheter (Ostrom, 1996). Återgår vi till hälso- och sjukvården betonas idag vikten av mer uttalat samskapande hälso- och sjukvård (M. Batalden et al., 2016). Det innebär att involvera vårdtagare som kompetenta, kunniga partners i hälso- och sjukvårdens alla områden, genomförande, utveckling och utvärdering (Dunston, 2014). Dunston menar att samskapande hälso- och sjukvård innebär ett kraftfullt skifte i hur vårdgivare förstår vårdtagarens perspektiv. Detta utmanar vårdgivarnas expertkunnande som överordnat, deras professionella identitet samt utformning av utbildning och lärande i dagligt arbete.

De förändringar som de dagliga hälso- och sjukvårdsverksamheterna står inför är mångfacetterade. Samtidigt finns uttalade krav på att vården ska vara av god kvalitet, säker och tillgänglig för alla. Fortfarande är den systematiska kunskapen sparsam om hur hälso- och sjukvårdens verksamheter bör genomföras för att kunna uppfylla de beskrivna förväntningarna.

\section{Det dagliga hälso- och sjukvårdsarbetet}

Det dagliga hälso- och sjukvårdsarbetet bedrivs på varierade sätt inom olika discipliner i slutenvård, inom primärvård och annan närsjukvård. 
Ett traditionellt sätt att beskriva en vårdenhets arbete är att utgå från dess ledning och målsättning, involverade yrkesgrupper och deras ansvarsområden. Vidare vilka patientgrupper vårdenheterna ansvarar för och antalet sängplatser med beläggning eller antalet patientbesök under en tidsperiod. Slutligen brukar vårdens resultat inom olika parametrar från register och annan data beskrivas. Ett sådant sätt att beskriva hälsooch sjukvårdsarbetet återger vad arbetet består av och mätbara resultat, men inte hur det dagligen genomförs och vad det betyder för vårdgivare och patienter.

En utgångspunkt för denna avhandling är att det för att kunna beskriva hur dagligt hälso- och sjukvårdsarbete utförs, behövs utgångspunkter i konkret genomförande i specifika sammanhang. Beroende på om utgångspunkten är en enskild vårdenhets eller en professions dagliga arbete eller en patients/patientgrupps väg igenom vården under en tidsperiod, betonas olika delar av vårdens komplexitet. Några generella drag i det dagliga arbetet kan beskrivas på följande sätt. Det går inte att på förhand förutsäga hur de patientrelaterade uppgifterna under en dag kommer att te sig; både oväntade och akuta situationer förekommer dagligen vilket medför att vårdgivare har snabba kast i sitt arbete. Vårdgivare agerar för att medicinskt utreda, bedöma och behandla, bidra i omvårdnad och rehabilitering. De planerar nästa steg i vården och dokumenterar det som genomförs med eller för patienter. Arbete kan pågå med ett flertal patienter parallellt och inkludera interaktion mellan olika professioner. Vårdgivarna interagerar med varandra och med aktörer på andra enheter inom och utanför verksamheten utifrån sina specifika ansvarsområden. I arbetet ingår också, att skapa förutsättningar för bra verksamhets integrerat lärande (VIL) för studenter.

På olika vårdenheter arbetar olika professioner stationärt eller delar av sin arbetstid. Upprättade rutiner är kopplade till teknisk utrustning, rumsliga förhållanden och till dygnets timmar. De är utformade så att vårdgivarna och olika vårdenheter ska kunna kalibrera varandras uppgifter så att individuella patientprocesser fortskrider. Komplext hälsooch sjukvårdsarbete kan fångas med hjälp av modellen kliniska mikrosystem (Nelson et al. 2007). I modellen definieras kliniska mikrosystem som grupp professionella som regelbundet arbetet tillsammans och ger service till en avgränsad patientpopulation och som har gemensamma mål, processer, informationssystem samt resultatuppföljning. Det är i kliniska mikrosystem som vårdens värden 
skapas och det är först och främst där förändringar kan leda till att förbättringar.

Dagligt hälso- och sjukvårdsarbete i Sverige är i många avseenden välfungerande, men förändringar behövs då nya utmaningar behöver mötas, inklusive stress och frustration som signaleras i samhällsdebatten och bekräftas i olika studier (SOU 2016:2). Wolf et al. beskrev hälso- och vårdsammanhang med minimalistisk design och rutinfokuserade vårdgivare med sparsamma dialoger i multiprofessionellt team-arbete, vilket begränsade för både patienter och vårdgivare i olika valsituationer. Det riskerade att skapa moralisk stress i brytningen mellan biomedicinska och personcentrerade arbetssätt (Wolf, Ekman, \& Dellenborg, 2012). Vid oenigheter i teamarbete inom intensivvården var det stressande för alla vårdgivare och det fanns både maladaptiva ageranden (meningsutväxlingar, stridigheter, tillbakadragande) och konstruktiva (ventilerande, stödjande nätverkande, utvecklad teamsammanhållning) för att hantera det (Bruce, Miller, \& Zimmerman, 2015). Även om många patienter var nöjda med den slutenvård de fått, fanns grupper som under vårdtiden var och förblev osäkra och oroliga och sedan lämnade sjukhuset med stressymptom (Jakobsson, Jakobsson Ung, Lindström, Ringström, \& Eliasson, 2018). Både vårdgivare och vårdtagare är pressade i vården och det är till stor del de som behöver skapa mer välfungerande vårdsituationer.

Även om vårdgivare strävar efter att kunna omsätta nya kunskaper och genomföra ett evidensbaserat dagligt arbete, är det svårt att realisera (Carlfjord \& Festin, 2014). Författarna menar att strategier som är enkla att använda, som upprätthåller patienternas integritet och som formas genom "bottom-up" snarare än "top-down" ageranden är underlättande. Men det riskerar att motverkas av att administrativa bördor i det dagliga arbetet har ökat. Förutom patientrelaterad dokumentation är bördorna relaterade till dåligt fungerande IT-baserade verksamhetssystem och en övergripande strävan att följa upp och riskminimera hälso- och sjukvården (SOU 2016:2). En amerikansk tidsstudie av läkare inom fyra specialiteter visade att för en timme i direkt arbete med patienter, använde läkarna mellan en och två timmar för olika former av administrativt arbete (Sinsky et al., 2016). Läkares administrativa börda räknades som den viktigaste orsaken till deras tilltagande otillfredsställelse med bristande balans mellan arbete och fritid samt den tydliga ökning av antalet professionella som blivit utbrända (Friedberg et al., 2014; Shanafelt et al., 2015). Friedberg et al. menade att otillfredsställda läkare är ett varningstecken för att läkare och/eller de 
vårdsammanhang de arbetar i genomför en vård som inte har en god kvalitet. Det är motivet till att jag i denna avhandling ta utgår i läkares lärande och interaktion i hälso- och sjukvårdsarbetet.

\section{Läkares lärande och interaktion i hälso- och sjukvårdsarbete}

Patientrelaterat arbete är det centrala i de flesta svenska läkares vardag. Komplexiteten i de sammanhang där vården utförs påverkar utvecklingen av och lärande i dagligt hälso- och sjukvårdarbete. Friedberg et al. har i en omfattande både kvalitativ och kvantitativ amerikansk studie, studerat läkares professionella tillfredställelse i sitt arbete (Friedberg et al., 2014). De konstaterade att de två viktigaste faktorerna för professionell tillfredsställelse var att kunna möta sina patienters behov med vård av hög kvalitet och att de elektroniska patientjournalerna var välfungerande. Vidare att arbeta med en grupp kunniga och kapabla kollegor och medarbetare i andra professioner genom samarbete som byggde på kollegialitet, ärlighet och respekt. Omfattning och tempo i arbetet och att ha kontroll över arbetet för att få tillräcklig tid med patienterna var betydelsefullt. Tillfredställande var också tillgängliga ledare med klinisk erfarenhet som hade gemensamma värderingar. Och att ledarna balanserade initiativ till förändringar genom att om möjligt upprätthålla läkarnas autonomi.

Alla nämnda faktorer genererade tillfredställelse när de uppfylldes, men otillfredsställelse och missnöje när arbetssituationen innebar motsatta förhållanden. Som exempel gav elektroniska patientjournaler tillgänglighet och resurser för kvalitet i patientarbete, men deras låga användarvänlighet skapade överskuggande frustration och missnöje. Friedberg och kollegor menade att det fanns en koppling mellan läkares professionella tillfredställelse och den kvalitet som patienterna erhöll i vården. När läkares missnöje kunde vara orsakat av upplevda kvalitetsproblem, kunde missnöjet vara en indikator på potentiell dysfunktion i vårdsystemet. Rekommendationen från författarna var att läkarna och deras interna vårdsammanhang i en sådan situation, behövde stöd av såväl kunskaper som resurser för att genomföra förändringar.

En svensk studie av Bååthe \& Norbäck (Bååthe \& Norbäck, 2013) visade att ledare, som ville engagera läkare i förändringsarbete och motverka kritisk inställning till systematisk kvalitetsförbättring, behövde förstå och uppskatta läkares professionella identitet. Därigenom menade författarna kunde ledare facilitera läkares engagemang, vilket troligen 
skulle utmana såväl ledares som läkares professionella identiteter. Sannolikt med varierande upplevelser och till nytta för vårdens utförande.

Till läkares identitet hör tillhörigheten till en profession med en lång historia. Inom den har medicinsk vetenskap utvecklat diagnostiska och terapeutiska processer och teknologier som vanligen varit organrelaterade (Marcum, 2008). Marcum beskriver att härigenom har den biomedicinska modellen åstadkommit enorma medicinska landvinningar. I modellen ingår att läkare rationellt beslutar om sjukdomars natur och ställer så exakta diagnoser som möjligt. Och genomför förmodat säkra och effektiva, vanligen farmakologiska eller kirurgiska behandlingar för att bota eller lindra sjukdom. Marcum skriver att den humanistiska läkekonsten som utgår från den hjälpsökande människans perspektiv (med variation mellan olika discipliner) däremot fått betydligt mindre utrymme inom medicinsk vetenskap, utbildning och praktiskt arbete.

I hälso- och sjukvården finns förändringstryck på läkares teoretiska kunskaper och tillämpning av ett flertal generella kunskapsområden, såsom kommunikation, samarbetskunskap, ledarskap och på alltmer interprofessionellt samarbete. Bakgrunden till förändringstrycket är att samarbete mellan vårdens professioner har varit bristfälligt och det har funnits begränsade erfarenheter av att arbeta tillsammans (Reeves et al., 2011). Det har medfört dålig koordination av och hämmat utförandet av patienters vård. Inomprofessionellt vårdarbete som huvudsakligen fokuserar på den egna funktionen, riskerar att leda till sämre vård och dåligt sammanhållna patientprocesser (Åhgren, 2010). Dåligt sammanhållna patientprocesser är också kopplade till läkares bristande kompetens inom generella kunskapsområden såsom kommunikation, ledarskap, teamarbete, systemförståelse och kvalitets- och förbättringsarbete (Lindgren \& Gordon, 2011). Kompetensbristen har under senare år mötts med förändringar i läkares utbildning både före och efter examen. Det är förändringar som påverkar hälso- och sjukvårdens dagliga arbete, där dessa utbildningsgrupper deltar och förväntas utveckla sitt kunnande.

Läkares utbildningsprocess från läkarstudent till AT-läkare (allmäntjänstgöring innan läkaren fått sin legitimation), ST-läkare (specialisteringstjänstgöring) och vidare till erfaren specialist skär hela vägen rakt in i och är knuten till det dagliga hälso- och vårdarbetet. Läkare har en lång utbildningstradition där akademiska studier, undervisning och forskning kombineras med kliniskt arbete. 
Läkarstudenter kombinerar de akademiska studierna med deltagande i hälso- och sjukvårdsarbete. Enligt Cooke et al. (2010) ska alla läkares utbildningsnivåer stimulera och stödja deras lärande till ett praktiskt klinisk arbete som kan sammanfattas i tre väsentliga domäner: patientvård, deltagande $\mathrm{i}$ professionella praktikgemenskaper samt utvärdering och utveckling av vården (Cooke, Irby, \& O'Brien, 2010). Avgörande är hur dessa mål varje dag förverkligas i konkret hälso- och sjukvårdsarbete. I Sverige har ST nyligen genomgått en reformering och AT och grundutbildningen håller på att reformeras. Konsekvenserna av reformerna medför förändrade och tydligare krav både på dem som är adepter i utbildningsprocesserna, på dem som skall möjliggöra och stödja deras lärande i det dagliga hälso- och sjukvårdsarbetet och på de verksamheter och deras ledningar där det skall genomföras.

Inom grundutbildningen planeras läkarstudenters verksamhetsintegrerade lärande (VIL) att öka i omfattning med stöd av olika pedagogiska modeller (Läkarutbildningsutredningen, 2013). Läkarstudenter förväntas vara än mer aktiva i hälso- och sjukvårdsarbete för att integrera teoretiska kunskaper med sitt eget agerande i autentiska vårdsituationer, med utgångspunkt i både medicinska och generella lärandemål. Utredningen Bastjänstgöring för läkare (2017) föreslår att AT tas bort och ersättas med en förlängning av grundutbildningen fram till legitimation samt ett kliniskt basår (BT) före ST. Sådana förändringar medför både strukturella och utbildningsmässiga konsekvenser i vårdens verksamheter och för läkare på alla utbildningsnivåer i deras dagliga arbete.

ST-läkare ska uppnå sina kompetensmål genom klinisk tjänstgöring under handledning, det vill säga det dagliga hälso- och sjukvårdsarbete, som kompletteras med avgränsade kurser och andra lärandemetoder (SOSFS 2015:8). Kraven på måluppfyllelse är jämfört med tidigare riktlinjer skärpta och engagerar både ST-läkare, deras handledare, andra läkare, medarbetare och ledningar inom hälso- och sjukvården. De specialitetsspecifika medicinska målen ställer krav på hur ST-läkare inom respektive specialitet ges förutsättningar att arbeta så att målen kan uppfyllas. De generiska kompetensmålen, som exemplifierats ovan, har utvidgats och vikten av dem har speciellt betonats.

I hälso- och sjukvårdsarbetet finns begränsade erfarenheter och traditioner av att uppmärksamma ST-läkarnas lärande inom ramen för de generella målen. Specialister och äldre läkare som ska bedöma STläkarnas måluppfyllelse har i regel begränsad eller ingen teoretisk utbildning inom de områden målen täcker, utan har utvecklat sitt 
kunnande inom ramen för kliniskt arbete. I ett flertal andra länder har initiativ tagits för att möta kraven på ST-läkares lärande i kliniskt arbete genom Competency-Based Medical Education (Carraccio, Wolfsthal, Englander, Ferentz, \& Martin, 2002; Frank et al., 2010). CBME fokuserar avgränsade mål och hur de omsätts av ST-läkare i kliniskt arbete och bedöms av deras handledare. Kritiker menar att CBME tar stora resurser i anspråk och ställer mycket höga krav på utveckling av handledares kompetens (Frank et al., 2010; Frenk et al., 2010; Hawkins et al., 2015; Norman, Norcini, \& Bordage, 2014; Parent, Jouquan, \& De Ketele, 2013). Vidare att man riskerar att inte ta hänsyn till att generiska mål till sin natur är komplext integrerade med varandra och beroende av specifika kliniska sammanhang.

De mångdimensionella förändringar i hälso- och sjukvården som beskrivits är av betydelse för vårdens utförande och kvalitet både kortoch långsiktigt. Åtskilliga av de behov av förändringar som formulerats är relaterade till kunskap, utveckling av kunskap och därmed lärande. I dagligt hälso- och sjukvårdsarbete sker lärande och pedagogiskt agerande, som på olika sätt innefattar alla deltagare. För att läkare tillsammans med dem de interagerar med ska kunna omsätta förändringstrycket på ett konstruktivt sätt, behövs en fördjupad förståelse för hur lärande i det dagligt hälso- och sjukvårdsarbete går till.

\section{Lärande i professionella praktiker}

Genom att betrakta hälso- och sjukvården som en mångfald av professionella praktiker, kan vi få breda och djupa perspektiv på lärande i komplext dagligt hälso- och sjukvårdsarbete. Praktiker är universella och innefattar mer än vad människor praktiskt utför. Professionella praktiker är sociala, situerade i tid och rum och har intentioner, det vill säga det en grupp yrkesutövande människor avser att genomföra på ett meningsfullt sätt på en specifik plats och under en viss tid (Kemmis, 2011).

Deltagare i professionella praktiker utvecklar gemensam tillhörighet och legitimt engagemang i det som framstår som meningsfullt och etiskt ändamålsenligt i praktiken. I en sådan utveckling förfinar praktiker kontinuerligt sitt praktiska genomförande (Gherardi, 2012). Genomförande av förändringar eller innovationer bygger inte enbart på planerade punktinsatser som utifrån förs in i praktiken. Gherardi menar att förändringar och innovationer kan betraktas som kontinuerliga processer i pågående arbete på arbetsplatser. I förändringsprocesser spelar kunnande en nyckelroll för förändringar och innovationer. 
Förändringsprocesser är inte separata, eller möjliga att separera från lärande, arbete eller organiserande.

I hälso- och sjukvårdspraktiker utvecklar professionella tillsammans kunskaper som är betydelsefulla för arbetets genomförande, organisering och förändring. Lärande blir en kollektiv aktivitet, vilket tydliggör att det inte är kunskap som ett objekt som några äger som är intressant att fokusera (Gherardi, 2012). Ett praktikbaserat perspektiv på arbetsplatsbaserat lärande tydliggör att det inte räcker med ett kognitivt perspektiv på lärande (personers förståelse och individuella mentala bearbetning) för att fånga vad som verkligen sker och kan förändras. När lärande ses som en individuell, intern och huvudsakligen kognitiv process separeras andra människor och materiella förhållanden från den som lär och från de processer som lärande utgör (Fenwick, 2008).

Genom att studera specifika hälso- och vårdpraktiker med ett praktikteoretiskt perspektiv har Kilmister och medförfattare, utvecklat konceptet "kritiska intensiva lärperioder" (CILP), perioder som underläkare befinner sig i när de kommer till en ny arbetsplats (Kilminster, Zukas, Quinton, \& Roberts, 2010). Hur medarbetare och ledare på dessa arbetsplatser agerade hade betydelse för vilket lärande underläkare hade möjlighet att utveckla. Zukas och Kilminster menar att medicinsk verksamhetsförlagd utbildning är för fokuserad på formella, kodifierade kunskaper och brister i dagliga aspekter av underläkares lärande.

Utifrån de förändringar och utmaningar hälso- och sjukvården står inför, är det angeläget att synliggöra hur lärande och pedagogiska processer sker i hälso- och sjukvårdens praktiker. Ett praktikbaserat perspektiv, i det här fallet med avgränsning till pedagogiska praktiker (såsom i hälsooch sjukvården) kan tydliggöra processer som influerar lärande i dagligt arbete (Fenwick, 2008). Praktikteoretiska studier av hur specifika hälsooch sjukvårdspraktiker fungerar kan på så sätt även utmana andra hälsooch sjukvårdspraktiker, visa på möjligheter till förändring (Mahon, Kemmis, Francisco, \& Lloyd, 2017) och hur dessa kan hanteras. Det finns inga tidigare studier ned en sådan forskningsdesign.

Med praktikteoretiska perspektiv på komplexiteten i dagligt patientrelaterat hälso- och sjukvårdarbete, kan aspekter för lärande och samspel synliggöras och bättre förstås. Det är just relationerna mellan de många aspekterna som är involverade i hälso- och vårdpraktiker och som formar lärande och samspel, som är fokus för denna avhandling. 


\section{AVHANDLINGENS SYFTE}

\section{Övergripande forskningsfrågor}

Avhandlingens övergripande syfte är att fördjupa kunskapen om och förståelsen av pedagogiska processer och lärande i hälso- och sjukvårdspraktiker, med särskilt fokus på läkare och lärande.

Mer specifikt besvaras följande frågor:

- Hur beskriver hälso- och sjukvårdspersonal sitt dagliga arbete och vilka pedagogiska processer framträder $\mathrm{i}$ beskrivningarna av samspel med patienter? (I)

- Hur beskriver läkare sitt dagliga arbete och på vilket sätt framträder deras lärande och stöd till andras lärande? (II)

- Hur påverkar materiella och sociala förhållanden i en specifik hälso- och sjukvårdspraktik samspelet mellan dess deltagare? (III)

- Hur lär underläkare* i det arbete de är engagerade i, när de deltar i en specifik hälso- och sjukvårdpraktik? (IV)

*med underläkare avses både AT- och ST-läkare 


\section{TEORETISKT RAMVERK}

Genom att förankra avhandlingen $\mathrm{i}$ det medicinsk pedagogiska forskningsparadigmet, făr pedagogiska aspekter vetenskaplig tyngd och förankring. Medicinsk pedagogik har varit en akademisk angelägenhet i mer än 50 år, med historia främst inom forskning omkring grundutbildningen. Dagens forskning omfattar också olika perspektiv på hälso- och sjukvård i stort och har gått från kvantitativ metodologi till att innefatta en bredd av kvalitativa och teoridrivna studier. Hodge and Kuper beskriver biovetenskapliga-, lärande- och sociokulturella teorier som betydelsefulla för fördjupade kunskaper om läkares lärande efter grundutbildningen (Hodges \& Kuper, 2012). Att använda teori i forskning möjliggör att fånga komplexa sociala fenomen inom medicin och vård, Rees och Monrouxe betonar vikten av socialkonstruktivism med tolkande forskningsansatser (Rees \& Monrouxe, 2010). Lärande och interaktion i hälso- och sjukvårdspraktiker är komplexa sociala fenomen som omfattas av många aspekter i konkret utförande.

\section{Praktikteori}

För att kunna fördjupa kunskapen om sambanden mellan de många aspekter som är involverade i hälso- och sjukvårdspraktiker och som formar lärande och samspel, väljer jag att studera autentiskt hälso- och sjukvårdsarbete genom praktikteoretiska linser. Praktikteorier möjliggör för mig att utforska och beskriva det som sker i professionella praktiker av konkret dagligt hälso- och sjukvårdsarbete utifrån flera dimensioner. Det vill säga det som sker i samspel mellan vårdgivare och patienter och mellan vårdgivare i olika professioner för att utföra god och säker vård samt mellan generationer av vårdgivare $i$ handledande situationer för att nå konstruktiv kompetensutveckling. Hälso- och sjukvårdspraktiker är uni- eller multidisciplinära och/eller multiprofessionella och specifikt formade socialt och etiskt av respektive professionsområde. "Professionell" syftar här inte bara på kopplingen till specifika yrkesområden, utan också på sättet att vara "professionell" i praktiken (Francisco, Mahon, \& Kemmis, 2017a). Praktikteoretiska perspektiv kan tydliggöra hur deltagare i praktiker agerar och interagerar, hur de relaterar till varandra och miljön och hur de utvecklar professionalitet. 
Praktikteori är ett brett fält av sociala och kulturella teorier som relaterar till varandra genom att de just fokuserar praktiker i det "dagliga" (Green, 2009; Nicolini, 2014; Schatzki, 2002). Praktikteorier har gemensamt att de betraktar praktiker som sociala, relationella och situerade. De avvisar dualismer såsom kropp och själ, agerande och tänkande, struktur och process (Reckwitz, 2002). Intresset ökar för att bättre förstå hur autentiskt praktiskt arbete på arbetsplatser görs och hur detta hänger samman med hur verksamheter, till exempel hälso- och sjukvård organiseras (Nicolini, 2011). Ett flertal praktikteorier har utvecklats som fördjupar förståelsen för vad som formar, upprätthåller och transformerar professionella praktiker och för vad som håller tillbaka, begränsar och gör dem instabila (Fenwick, Edwards, \& Sawchuk, 2011; Schatzki, 2002).

I konsekvens med ett praktikteoretiskt perspektiv, utgör lärande och pedagogiska processer praktikbaserade förändringar som är inbäddade i det dagliga arbetet (Fenwick, 2008). Praktikbaserade teorier förskjuter därmed fokus från att individuellt behärska kunskap och kunskapsöverföring mellan individer till kunnande och lärande i praktiker (Hopwood, 2014). Praktikteorier avvisar generellt kognitiv faktakunskap som det enda sättet att beskriva professionell kunskap (Reich \& Hager, 2014). Reich \& Hager menar istället att professionell kunskap även är förkroppsligad och åstadkommen i och genom lärande i praktiker.

I avhandlingens delarbeten används olika praktikteoretiska perspektiv, för att besvara forskningsfrågorna och därigenom få bredd och djup i förståelsen av lärande och samspel i hälso- och sjukvårdspraktiker. I delarbete I används en sociokulturell lins (Mann, 2011) för att kunna beskriva vårdgivares pedagogiska processer och förstå hur de är förankrade i praktikerna. Ett sidofynd i det första delarbetet var att praktiksammanhangen var av uttalad betydelse för informanternas arbete och lärande. Dessa iakttagelser väckte mitt intresse för sociomateriell praktikteori och medförde att jag bland bredden av teoretiska inriktningar valde ett sociomateriellt ramverk om praktikarkitekturer (Kemmis, 2011) för de kommande studierna. Hälso- och sjukvårdspraktiker är i många avseenden både sociala och fysiska med betydelse av enskilda personer agerande såväl som extra-individuella förhållanden (Kemmis, 2011) i och mellan praktiker. Det praktikteoretiska ramverket praktikarkitekturer har utvecklats inom ramen för skolans värld, men forskargruppen menar att det har vidare relevans än så: 
[T] he educational practices in the Education Complex are not vast social structures' that order the world uniformly throughout a classroom, school, School District or national jurisdiction. On the contrary, they are realised in everyday interactions between people, and between people and other objects in millions of diverse sites around the world. (Kemmis 2014 s 52)

Ramverket tillhandahåller flera analytiska redskap, som jag använder för att studera olika aspekter av hälso- och sjukvårdspraktiker. I delarbete II används perspektivet för att fokusera former för agerande i praktiker, kopplingar mellan praktiker och deras praktikarkitekturer fokuseras i delarbete III och slutligen ekologiska kopplingar mellan flera olika praktiker är den teoretiska linsen i delarbete IV. Till skillnad från andra sociomateriella praktikteoretiska inriktningar tillhandahåller Kemmis ramverk, även om det är omfattande, ett tillgängligt och koncist språk för att be-skriva och tolka komplext hälso- och sjukvårdsarbete. Det möjliggör att empiriskt identifiera hur praktiker och praktikarkitekturer och flera praktiker relaterar till varandra och hur de är beroende av varandra. Därigenom kan jag fånga komplexiteten i hur lärande och samspel formas i hälso- och sjukvårdspraktiker. I den analytiska processen bidrar teorin till att fokusera det som sker och att identifiera de specifika arrangemang som varje praktik formas av. Utifrån intresse av hur "stora fenomen" kan förstås genom praktikteoretiska perspektiv, menar Nicolini att Kemmis och hans kollegor tillhör de få som har möjliggjort praktiska sätt att studera och beskriva sammankopplingarna mellan praktiker och vilka effekter det făr (Nicolini, 2016).

Att betrakta hälso- och sjukvården som en lärandepraktik är högst relevant och kan betraktas som ett "stort fenomen" som är angeläget att bättre förstå. Studier av hälso- och sjukvården med olika avgränsade perspektiv på framförallt utbildning men också lärande har genomförts i decennier och är många. Men praktikbaserade studier som sätter hälsooch sjukvårdspraktikers sociomateriella förhållande och dess betydelse för lärande och samspel i fokus (inte enskilda individer eller funktioner) är ovanliga. Det motiverar både avhandlingens syfte och valet av forskningsfrågor i kombination med olika praktikteoretiska perspektiv som analysiska redskap. I det följande beskrivs ytterligare de praktikteorietiska perspektiven som används i avhandlingen.

\section{Sociokulturellt perspektiv}

Ur ett sociokulturellt perspektiv på praktiker är relationer, strukturer och kulturer centrala (Mann, 2011). Praktikerna består av diskurser (hur 
språket formas i och formar praktiken) och handlingar, som är strukturerade och situerade. Fokus ligger på att vara deltagande socialt och relationellt $\mathrm{i}$ en praktik. Inom de normer, värderingar och verklighetsuppfattningar som råder i en praktik, söker deltagarna sin identitet i samspel med andra deltagare (Vygotskij, Hanfmann, Vakar \& Kozulin, 2012).

Lave och Wenger (1991) har utvecklat en specifik sociokulturell teori som beskriver praktiker som praktikgemenskaper (community of practice) (Kerno \& Mace, 2010). En praktikgemenskap är en avgränsad grupp människor som delar mål, värderingar och repertoarer av beteenden i sin sysselsättning (Wenger, 1998). Fokus är vad som sker socialt i en praktik och hur praktiker upprätthålls. Medlemmarna i en praktikgemenskap delar perspektiv och sätt att förklara sitt sammanhang, de förhandlar tillsammans fram tolkningar av centrala begrepp och hur verksamhetens mål ska nås. Genom sådant förhandlande uppnår de ömsesidigt engagemang och delar åtagande, med en gemensam repertoar av teorier, språk, förhållningssätt och metoder. Wenger hävdar att identitetsutvecklingen är både individuell och multipel på samma gång (Wenger, 1998).

I praktikgemenskaper är lärande invävt i utveckling av gemensam identitet (Lattuca, 2002; Lave \& Wenger, 1991). Deltagare utvecklas och lär genom att delta i praktiken (Lattuca, 2002; Vygotskiŭ, 2012). Lärandet tydliggörs genom att deltagare i det praktiska arbetet rör sig från legitimt perifert deltagande till att över tid bli allt mer centralt deltagande, när de blivit familjära med praktikens kultur och kommunikationsmönster (Wenger, McDermott, \& Snyder, 2002). Det sätt på vilket deltagare talar i och om den professionella praktik de är en del av både, formar praktiken och formas av praktiken.

\section{Sociomateriella perspektiv}

Sociomateriella perspektiv tydliggör att praktiker inte enbart är formade socialt av personers erfarenheter, intentioner, personligheter och agerande (Kemmis et al. 2012, 2014). Olika aspekter av materialitet såsom redskap, teknologier, andra föremål och rumsutformning såväl som människors kroppar bidrar till formandet av praktiker, tillsammans med sociala och relationella förhållanden (Fenwick, 2010). Sådant som traditionellt tas för givet som bakgrundsfaktorer flyttas därmed fram i förgrunden. Det finns ett flertal olika praktikteoretiska perspektiv som betonar vikten av att också inkludera materiella förhållanden (Fenwick, Edwards, \& Sawchuk, 2011). 
Kunnande och lärande har beskrivits på ett flerartal sätt utifrån sociomateriella praktikteoretiska perspektiv. Såsom kunnande-i-praktiker (knowing in practice) som beskrivs som kunnande i praktiker som situerad, i samspel förhandlad och som framträdande i aktiviteter(Gherardi 2009). Kunnande är här ett ord som förmedlar synen att kunskap framträder i görandet, till skillnad från synen på kunskap som en produkt som kan överföras. Det betyder att kunnande-i- praktiker förnyar sig själv och transformerar sig själv genom att praktiseras. Reich och Hager betraktar "praktiker som kollektiva och situerade processer som länkar kunnande, arbetande, organisering, lärande och innovationer " (Reich \& Hager, 2014 s. 421).

I avhandlingen har framför allt Kemmis praktikteoretiska ramverk tillämpats (Kemmis, 2014). Kemmis bygger det på Schatzkis praktikteoretiska perspektiv och "site ontologi" (Schatzki 2002). Schatzki menar att praktiker är det "primärt generiskt sociala" (Schatzki $2002 \mathrm{~s}$. 25, 29). "Site ontologi" innebär att det specifika innehållet och utförandet av praktiker uppmärksammas, deras organisation i tid och rum, arrangemangen som möjliggör och upprätthåller dem, deras förändringar och sammanhangen de finns i. En praktik kan vara lokaliserad i multipla sammanhang samtidigt (såsom den medicinska praktiken på en kliniks avdelningar, mottagning och akutverksamhet). En praktik kan också vara beroende av andra praktiker och den kan vara sammanhanget för en annan praktik (såsom rondpraktiken är en del av avdelningspraktiken) (Francisco et al., 2017a).

Francisco et. al. beskriver praktiker som "socialt samverkande mänskliga aktiviteter som involverar former av uttryck och förståelse (sägande), sätt att agera (göranden) och tillvägagångsätt att relatera till varandra och omvärlden (relateranden) som 'hänger samman' på karaktäristiskt sätt i tydliga 'projekt”' (Francisco et al., 2017a s. 8) (fig. 2). En praktiks olika projekt omfattar intentioner, ageranden (sammankopplade "säganden", "göranden" och "relateranden") och avslut, som tillsammans motiverar och åstadkommer praktiken i dess olika delar och förhoppningsvis utmynnar i önskat resultat. Såsom när en läkare medicinskt handlägger en patients ohälsa, där ett projekt är att genomföra en kroppundersökning. En praktiks "säganden", "göranden" och "relateranden" sker tillsammans och kan inte separeras i de projekt som praktiken utför (Francisco et al., 2017a). Praktiker blir distinkta och tydliga genom det specifika sätt som deras "sägande", "görande" och "relaterande" hänger samman. 
Figur 2. Praktiker formas av "sägande, görande och relaterande som hänger ihop i projekt. Översatt från (Kemmis, 2014 s. 33).

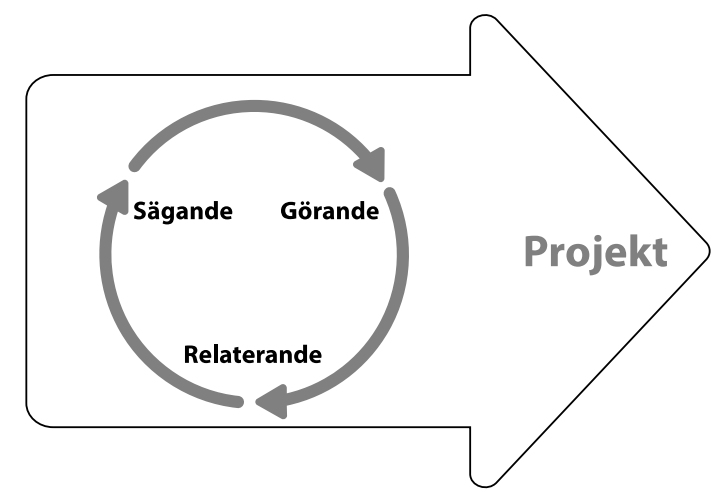

I delarbete II använder jag mig av Kemmis "sägande", "görande" med materiella arrangemang och "relaterande", för att i läkares berättelser om sitt dagliga arbete spåra hur läkare samspelar med patienter och andra medarbetare. Och därigenom kunna tydliggöra deras lärande och stöd till andras lärande.

Kemmis menar att det finns extra-individuella förhållanden som möjliggör och upprätthåller praktiker och som existerar oavsett enskilda personers aktiviteter (Kemmis \& Mutton, 2012). Dessa extraindividuella förhållanden eller arrangemang tillsammans med det som sker i praktikens projekt ingår i Kemmis centrala koncept praktikarkitekturer. Praktikarkitekturer utgör det analysiska redskapet i delarbete III.

\section{Praktikarkitekturer}

Praktikers praktikarkitekturer är distinkta arrangemang (extraindividuella) som både möjliggör, formar och formas av sina praktiker (Kemmis, 2014; Kemmis \& Mutton, 2012). Det är tre olika typer av arrangemang som samtidigt existerar i sammanhanget för en praktik; kulturellt-diskursiva, materiellt-ekonomiska och socialt-politiska arrangemang. Arrangemangen utgör medier och utrymmen för praktiken. Praktikerna är på ett dynamiskt sätt sammanflätade med dessa arrangemang. Dessa arrangemang beskrivs utförligare i det följande (fig. $3)$. 
Figur 3. Medierna och utrymmena där "sägande", "görandet" och relaterandet existerar (Kemmis, 2014 s. 34).

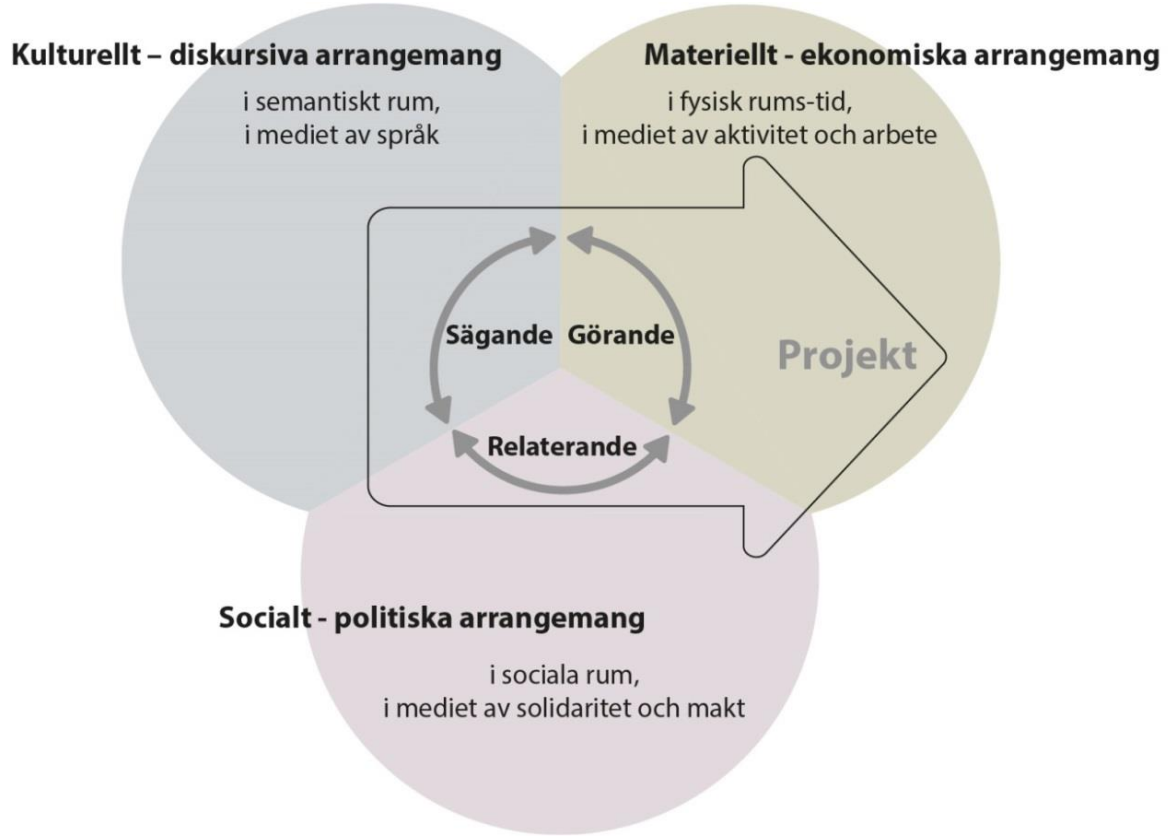

- Kulturellt-diskursiva arrangemang är i bred bemärkelse resurser som formar och möjliggör en praktiks "säganden", såsom språk, sätt att resonera och vad som på olika sätt anses relevant och lämpligt att uttrycka (och tänka) i och om praktiken.

- Materiellt-ekonomiska arrangemang är resurser som formar själva "görandet", vad, när, hur och av vem eller vad något genomförs. Vidare den materiella omgivningen, redskap, andra föremål samt finansiella och mänskliga resurser.

- Socialt-politiska arrangemang är resurser som formar hur personer relaterar till varandra och till icke mänskliga objekt. Det inkluderar former för solidaritet och makt, organisatoriska regler, relationer i mindre grupper, i organisationer eller i samhällen.

Praktikernas sociala värld är uppbyggd av det som sker i relation till dessa arrangemang. I det semantiska rummet möts personer på olika sätt genom det språkliga mediet. I den fysiska rums-tiden samspelar personer med sina kroppar och med hjälp av redskap som medierar aktiviteter och arbete. Och slutligen i det sociala rummet medieras olika former för 
solidaritet och makt. Praktikarkitekturer utgör förhandsvillkor som möjliggör, håller samman och prefigurerar vilken praktik som kommer att utspela sig. Med prefiguration avses avgränsade förutsättningar som formar, underlättar, skapar eller begränsar vad som utförs i en praktik. Men det går inte att på förhand avgöra vad arrangemangen i praktikarkitekturerna kommer att bidra med, det är i skeendet som de prefigureras, dvs. får sin betydelse genom hur de används.

Kemmis \& Mahon (2017) menar att lärande i praktiker är både kollektivt och individuellt och framträder i praktikarkitekturernas intersubjektiva rum (ett rum som ligger mellan människor) och medium (figur 4).

Figur 4. En teori om lärande i hälso- och sjukvårdens (HoS) praktiker som bygger på Kemmis teori om utbildning. Figurens utformning är inspirerad av (Kemmis \& Mahon, 2017 s. 235), praktikarkitekturer (Kemmis, 2014 s.38).

Den individuella sidan

vårdgivare och patienter

\begin{tabular}{|c|c|c|c|c|}
\hline $\begin{array}{l}\text { Lärande } \\
\text { som initiering in i HoS } \\
\text { praktiker... }\end{array}$ & $\begin{array}{l}\text { former av } \\
\text { förståelse }\end{array}$ & sätt att agera & $\begin{array}{l}\text { tillvägagångs } \\
\text { sätt att relatera }\end{array}$ & $\begin{array}{l}\text {...för aktivt ta del av } \\
\text { och genomföra god } \\
\text { och säker vård }\end{array}$ \\
\hline $\begin{array}{l}\text { Praktiker } \\
\text { är interaktivt utförda genom... }\end{array}$ & $\begin{array}{l}\text { "sägande" } \\
\text { och tänkande } \\
\text { (kognitivt) }\end{array}$ & $\begin{array}{l}\text { "görande" } \\
\text { (psykomotoriskt) }\end{array}$ & $\begin{array}{l}\text { "relaterande" } \\
\text { (affektivt) }\end{array}$ & $\begin{array}{l}\text {...som binds samman } \\
\text { i praktikens projekt }\end{array}$ \\
\hline $\begin{array}{l}\text { Intersubjektivt } \\
\text { rum/medium: }\end{array}$ & $\begin{array}{l}\text { Sematiskt rum, } \\
\text { med språket } \\
\text { som medium }\end{array}$ & $\begin{array}{l}\text { Fysisk rum-tid, } \\
\text { med aktivitet } \\
\text { och arbete som } \\
\text { medium }\end{array}$ & $\begin{array}{l}\text { Socialt rum, } \\
\text { med makt och } \\
\text { solidaritet som } \\
\text { medium }\end{array}$ & \\
\hline $\begin{array}{l}\text { Praktikarkitekturers } \\
\text { arrangemang som möjliggör } \\
\text { och begränsar agerande och } \\
\text { interaktion genom... }\end{array}$ & $\begin{array}{l}\text { kulturellt- } \\
\text { diskursiva } \\
\text { arrangemang }\end{array}$ & $\begin{array}{l}\text { materiellt- } \\
\text { ekonomiska } \\
\text { arrangemang }\end{array}$ & $\begin{array}{l}\text { socialt- } \\
\text { politiska } \\
\text { arrangemang }\end{array}$ & $\begin{array}{l}\text {...som är sammanflä- } \\
\text { tade på typiska sätt i } \\
\text { traditioner av en eller } \\
\text { flera praktiker }\end{array}$ \\
\hline $\begin{array}{l}\text { Hälso- och sjukvård } \\
\text { som gynnar individuella och } \\
\text { kollektiva... }\end{array}$ & $\begin{array}{l}\text { uttrycksätt för } \\
\text { att säkra vård- } \\
\text { och lärande } \\
\text { kultur }\end{array}$ & $\begin{array}{l}\text { utveckla säkert } \\
\text { genomförande } \\
\text { av vård med } \\
\text { varaktiga } \\
\text { resurer och } \\
\text { sammanhang }\end{array}$ & $\begin{array}{l}\text { ställningstagan- } \\
\text { de för rättvist } \\
\text { och demokra- } \\
\text { tiskt samman- } \\
\text { hang }\end{array}$ & $\begin{array}{l}\text {...för att praktikerna } \\
\text { ska tillhandahålla en } \\
\text { god och säker vård }\end{array}$ \\
\hline
\end{tabular}


När deltagare i praktiker interagerar framträder lärande i språkliga uttryck (former för förståelse), aktiviteter (sätt att agera) och i tillvägagångssätt när de relaterar till varandra och omgiviningen (Kemmis et al., 2013). Lärande rör sig från fas till fas medan deltagare utvecklar känsla för genomförandet, vilket är extra påtagligt för dem som är noviser i praktiken. Men alla deltagare är i olika faser av att utveckla sin effektivitet och virtuositet i praktiker, med mer eller mindre djupgående initiering in i praktiker. Kemmis och Mahons illustration av sin teori om utbildning har jag bearbetat för lärande i hälso-och sjukvården i figur 4. I hälso- och sjukvården framträder då kollektivt lärande genom hur hälsooch sjukvårdspraktiker förmedlar sin vård- och lärandekultur, säkrar sitt genomförande med kompetensmässiga och fysiska resurser och i ställningstagande för rättvisa och demokratiska sammanhang.

I delarbete III är mitt intresse att djupgående studera hur sociala och materiella förhållanden påverkar samspel och lärande i en specifik hälsooch sjukvårdspraktik. Jag genomför det med hjälp av linsen praktikarkitekturer och spårar därigenom hur lärande tar sig uttryck i sociomateriella relationer.

I delarbete III fanns indikationer på att underläkarnas lärande begränsades. Det väckte frågor som utgjorde utgångspunkten för avhandlingens fjärde delarbete där Kemmis teori om praktikers ekologier utgör den teoretiska och analytiska ramen.

\section{Praktikers ekologier}

Som tidigare nämnts kan en praktik vara sammanhang för andra praktiker och flera praktiker kan finnas i samma sammanhang. Kemmis har utvidgat teorin om praktikarkitektur med en underordnad teori om praktikers ekologier, för att kunna tydliggöra relationer mellan olika praktiker och hur de formar varandra (Francisco et al., 2017a; Kemmis, Edwards-Groves, Wilkinson, \& Hardy, 2012 s. 34). Teorin om praktikers ekologier har influerats av Capras ekologier i biologisk systemteori (Kemmis et al., 2012; Kemmis et al., 2014).

Kemmis bygger sin teori på att olika praktiker inte existerar isolerat $\mathrm{i}$ förhållande till varandra utan samexisterar i komplexa mönster "såsom levande system". Det rör sig om olika former av empiriskt identifierade ömsesidiga relationer mellan praktiker i konkreta sammanhang. Praktikerna är genom mänskliga sociala aktiviteter på distinkta sätt sammankopplade för att inbördes och med nödvändighet ordna och upprätthålla en praktik av ett visst slag och komplexitet. Exempel på 
sådana sammankopplingar är praktiker som ömsesidigt beroende ingår i nätverk, sammanflätade system och subsystem, överlappande funktioner, cykliska återkommande sammankopplingar och flöden av förhållanden som löper genom praktikerna. Genom praktikers ekologier kan komplexa beroenderelationer beskrivas som kan vara ensidiga eller ömsesidiga. Praktiker kan anpassa sig och utvecklas i relation till varandra, kan också begränsa och möjliggöra varandra och utgöra praktikarkitekturer för andra praktiker.

Genom att i delarbete IV utgå från professionspraktiker och hur de interagerar med varandra, undersöker jag hur underläkarpraktiken formar och formas av förutsättningar för lärande. De andra professionspraktikerna är överläkarpraktiken, sjuksköterskepraktiken, undersköterskepraktiken, den administrativen praktiken och ledningspraktiken.

För att fördjupat förstå och utveckla ny kunskap om pedagogiska processer och lärande i hälso- och sjukvårdspraktiker och fokusera på läkare och lärande däri, har jag valt att betrakta studerade praktikerna som sociokulturella eller sociomateriella verkligheter. Ett sådant betraktelsesätt baseras på att verkligheten är subjektiv och varierande (relativ) och därigenom grundas avhandlingen $\mathrm{i}$ en tolkande vetenskapstradition (interpretivism) (Bunniss \& Kelly, 2010). När jag utforskar det som sker i hälso- och sjukvårdspraktiker, gör jag det genom samspel med och aktivt iakttagande av deltagare i praktiker och helheten av praktiker. Sammanfattningsvis bygger handlingen på en sociomateriell kunskapssyn, där kunskap är konstruerad socialt, språkligt och materiellt och knuten till specifika sammanhang i tid och rum. 


\section{METOD}

\section{Metodologi}

Utifrån avhandlingens syfte och frågeställningar eftersträvar jag att fördjupa kunskapen om komplexa fenomen (lärande, pedagogiska processer och samspel) i sina naturliga sammanhang (hälso- och sjukvårdspraktiker), med stöd av beskrivna praktikteoretiska perspektiv som ger mig analytiska redskap. Genom att tillämpa en kvalitativ tolkande forskningsansats (Bunniss \& Kelly, 2010; Malterud, 2001) kan kunskap och förståelse fördjupas. Sammanhangen är av central betydelse för lärande, pedagogiska processer och sampel, därför är det i autentiska hälso- och sjukvårdspraktiker dessa fenomen studeras

De teoretiska perspektiven tillämpas på två sätt i studierna. I delarbete I analyseras data induktivt och resultaten, som i sig utgör en mikroteori, relateras till valda etablerade makroteorier. I delarbete II, III och IV används valda teoretiska perspektiv som analytiska redskap för att tolka insamlade data. De teoridrivna analyserna bidrar till att på ett ingående sätt kunna beskriva fenomen. Genom att på detta sätt tolka och vara en del av forskningsprocessen kan förutsättningar skapas för att generera ny kunskap och vara teoribildande (Bunniss \& Kelly, 2010).

\section{Design}

Avhandlingsarbetet delas upp i två studier. Den första studien fokuserar på vårdgivare i tre professioner från ett flertal discipliner, deras syn på sitt arbete och där i förekommande lärande och pedagogiska processer. I studien utgör olika former av intervjuer data till delarbete I och II (tabell 1). Den andra studien fokuserar en specifik hälso- och sjukvårdspraktik och däri förekommande sampel och lärande. Den studien genererar underlag till delarbete III och IV genom en interaktiv forskningsansats med fältstudiedesign, inkluderande varierande datakällor såsom informella samtal, observationer, intervjuer och dokument. I interaktion med deltagare, data och medforskare skapas genom den interaktiva ansatsen mening i det som uttrycks i ord, handlingar och materiella förhållanden. 
Tabell 1. Forskningsfenomen, studiedesign, informanter och datakällor.

\begin{tabular}{|c|c|c|}
\hline & Studie A & Studie B \\
\hline $\begin{array}{l}\text { Forsknings } \\
\text { fenomen }\end{array}$ & $\begin{array}{l}\text { Lärande och pedagogiska } \\
\text { processer i ett flertal hälso- och } \\
\text { sjukvårdspraktiker }\end{array}$ & $\begin{array}{l}\text { Lärande och samspel i en specifik } \\
\text { hälso- och sjukvårdspraktik }\end{array}$ \\
\hline Studiedesign & Kvalitativ intervjustudie & $\begin{array}{l}\text { Interaktiv forskningsansats med } \\
\text { fältstudiemetodik }\end{array}$ \\
\hline Informanter & $\begin{array}{l}\text { Arbetsterapeuter, läkare, } \\
\text { sjuksköterskor inom flera } \\
\text { discipliner }\end{array}$ & $\begin{array}{l}\text { En vårdavdelnings rondpraktiker } \\
\text { med dess deltagare och andra } \\
\text { relevanta personer }\end{array}$ \\
\hline Datakällor & $\begin{array}{l}\text { Individuella intervjuer } n=24 \text {, med } \\
\text { sex informanter vid tre tillfällen } \\
\text { under fem månder med en } \\
\text { telefonintervju åtta månader } \\
\text { senare. } \\
\text { Tre fokusgrupper, en i varje } \\
\text { profession } n=12 \text { (fem läkare) } \\
\text { Två teamintervjuer, fler professio- } \\
\text { ner } n=12 \text { (en läkare i varje grupp) } \\
\text { Samtliga bandinspelade och } \\
\text { transkriberade efter hand }\end{array}$ & $\begin{array}{l}\text { Informella samtal** } \\
\text { Rondobservationer (sex st)* } \\
\text { Deltagande observationer på } \\
\text { avdelningen och vid andra } \\
\text { möten** } \\
\text { Publicerade och opublicerade } \\
\text { dokument } \\
\text { Gruppintervjuer med professi- } \\
\text { onsgrupperna (fyra st)* } \\
\text { Lärandeseminarium** }\end{array}$ \\
\hline
\end{tabular}

\section{Metod studie A}

Det övergripande syftet med studie $\mathrm{A}$ var att utforska vårdgivares beskrivningar av sitt dagliga arbete samt lärande och pedagogiska processer som framträdde däri.

\section{Sammanhang och deltagare}

Forskargruppen bestod av fyra personer, en senior forskare inom pedagogik, en sjuksköterska, en arbetsterapeut och jag själv som läkare. Tillsammans utvecklade gruppen forskningsdesignen under forskningsprocessen, genomförde datainsamlingarna för studien och analysen för det första delarbetet. I andra delarbetet genomförde jag det analytiska arbetet med stöd av forskningshandledarna.

Studien genomfördes med medarbetare från ett regionsjukhus och från primärvården i samma hälso- och sjukvårdsregion. En skriftlig förfrågan skickades till verksamhetschefer vid verksamheter inom olika discipliner, som ombads att utse forskningspersoner. Forskningspersonerna var strategiskt utvalda; personer i tre professioner 
med olika patientrelaterade uppdrag inom medicin, omvårdnad och rehabilitering som arbetade i medicinska, opererande och psykiatriska specialiteter eller allmänmedicin. Vidare hade personerna varierande åldrar, kön, yrkeserfarenhet och positioner i vårdverksamheterna (från ST-läkare till vårdenhetschef och verksamhetschef). Det strategiska urvalet innebar att forskningspersonerna valdes för att få den maximala variation som behövdes för att få innehållsrika data (Carter, Ritchie, \& Sainsbury, 2009).

\section{Datainsamling}

För att brett fånga vårdgivares perspektiv genomfördes studien med både individuella intervjuer, fokusgrupper i varje profession, tvärprofessionella teamintervjuer och uppföljande telefonintervjuer (tabell1).

De individuella intervjuerna genomfördes med två forskningspersoner i respektive profession (arbetsterapeut, läkare, sjuksköterska) vid tre tillfällen under fem månader (totalt 18 intervjuer). Intervjuare var forskare som tillhörde samma profession som forskningspersonerna. Fokusgrupp-intervjuerna kompletterades med uppföljande telefonintervjuer vid ett fjärde intervjutillfälle sex månader senare (tabell 2).

De individuella intervjuerna genomfördes på forskningspersonernas arbetsplatser i slutet av en arbetsdag och varade ca 1 timme. För att förstå vad som hände under arbetsdagen och vad det betydde ombads forskningspersonerna att beskriva sin arbetsdag. När de gjorde beskrivningar som hade eller skulle kunna ha pedagogiska avsikter ställdes fördjupande frågor, för att genom mer detaljer kunna fördjupa förståelsen. Intervjumetodiken som användes betraktas som öppen (Martyn Hammersley, 2006), deltagarna ombads beskriva sin aktuella arbetsdag och därigenom kunde deras perspektiv synliggöras.

Efter att de individuella intervjuerna hade analyserats genomfördes möten i tre fokusgrupper i respektive profession (fem läkare, fyra sjuksköterskor, respektive tre arbetsterapeuter). Syftet var att få ytterligare klargöranden om pedagogiskt arbetet i vårdens vardagsarbete. Fokusgruppernas möten som varade ca 90 min leddes av forskaren som ingick i respektive profession. Då inbjöds forskningspersonerna att tala fritt om pedagogiskt innehåll och lärande $\mathrm{i}$ arbetet. Därefter presenterades de för och fick diskutera fyra nyckelkoncept från analysen av de 18 individuella intervjuerna och fick resonera omkring dem. Slutligen fick de läsa en sammanställning av de individuella intervjuerna 
från sin profession och kommentera om den överensstämde med deras erfarenheter av pedagogiskt innehåll i arbetet och om det fanns något de ville tillägga.

Tabell 2. Summering av metoder i de två delarbetena från studie A

\begin{tabular}{|c|c|c|}
\hline & \multicolumn{2}{|l|}{ Studie A en kvalitativ intervjustudie } \\
\hline & Delarbete I & Delarbete II \\
\hline Syfte & $\begin{array}{l}\text { Beskriva pedagogiska diskurser } \\
\text { genom att identifiera pedagogis- } \\
\text { ka processer och undersöka } \\
\text { medvetenhet om dessa }\end{array}$ & $\begin{array}{l}\text { Fördjupa förståelsen för hur } \\
\text { lärande framträder i läkarens } \\
\text { dagliga arbete }\end{array}$ \\
\hline $\begin{array}{l}\text { Forsknings- } \\
\text { frågor }\end{array}$ & $\begin{array}{l}\text { Hur beskriver hälso- och } \\
\text { sjukvårdspersonal sitt dagliga } \\
\text { arbete och vilka pedagogiska } \\
\text { processer framträder i beskriv- } \\
\text { ningarna av samspel med } \\
\text { patienter och anhöriga? }\end{array}$ & $\begin{array}{l}\text { Hur beskriver läkare sitt dagliga } \\
\text { arbete och på vilket sätt framträ- } \\
\text { der deras lärande och stöd till } \\
\text { andras lärande? }\end{array}$ \\
\hline $\begin{array}{l}\text { Studiens } \\
\text { deltagare } \\
\text { och situatio- } \\
\text { ner }\end{array}$ & $\begin{array}{l}\text { Strategiskt valda personer i tre } \\
\text { professioner inom } 12 \text { discipliner i } \\
\text { anslutnig till dagligt arbete }\end{array}$ & $\begin{array}{l}\text { De strategiskt valda läkarna i } \\
\text { studien fanns inom olika } \\
\text { discipliner, i anslutning till } \\
\text { dagligt arbete }\end{array}$ \\
\hline Dataanalys & $\begin{array}{l}\text { Induktiva analyser inspirerade av } \\
\text { grundad teori. } \\
\text { Preliminära resultat med en } \\
\text { mikroteori analyserades med stöd } \\
\text { av teorier om samspel och språk }\end{array}$ & $\begin{array}{l}\text { Induktiv tematisk analys av data } \\
\text { först från individuella intervjuer, } \\
\text { följt av gruppintervjuerna. Tredje } \\
\text { analysfasen var teoridriven analys } \\
\text { där tolkades fynden utifrån vald } \\
\text { sociomateriell praktikteori. } \\
\text { NVivo verktyg för att hantera data. }\end{array}$ \\
\hline $\begin{array}{l}\text { Teoretiska } \\
\text { ramar }\end{array}$ & $\begin{array}{l}\text { Sociokulturellt praktikteoretiskt } \\
\text { perspektiv; } \\
\text { praktikgemenskaper och diskurser }\end{array}$ & $\begin{array}{l}\text { Sociomateriellt praktikteoretiskt } \\
\text { perspektiv: "Sägande", "görande", } \\
\text { materiella arrangemang och } \\
\text { "relaterande" }\end{array}$ \\
\hline
\end{tabular}

För att också fånga pedagogiskt arbete i relation till de medarbetare som vårdgivare naturligt samarbetade med i vardagsarbetet genomfördes två teamintervjuer. Det medförde att ytterligare professioner deltog: ett rehabiliteringsteam (arbetsterapeut, fysioterapeut, kurator, logoped, läkare, psykolog, sjuksköterska, undersköterska, och vårdadministratör) samt ett team från en internmedicinsk slutenvårdavdelning (läkare, två sjuksköterskor, dietist och undersköterska). De fick resonera omkring frågorna: Finns det pedagogiska komponenter i ert arbete? och Vem gör vad i teamet?

I de uppföljande telefonintervjuerna från de individuella intervjuerna ställdes slutligen frågor omkring forskningspersonernas arbete och vad de 
individuella intervjuerna betytt för dem. Alla intervjuerna spelades in och transkriberades i anslutning till genomförandet av intervjuerna.

\section{Analys delarbete I}

Analysen inspirerades av tillvägagångsättet inom grundad teori och pågick parallellt med och var vägledande för progressen av datainsamlingen. Grundad teori används inom forskning som söker förståelse och förklaringar på sociala processer och är teorigenererande (Glaser, 2017). Genom att tillämpa grundad teori kunde vi när forskningspersonerna talade i sitt arbete spåra hur de talade om pedagogiskt innehåll och deras medvetenhet om det. De fynd och teorier som därigenom genererades "grundades" i upprepade cykler av systematiskt insamlade och analyserade data. Denna systematik expanderade, förfinade och utmanade de framväxande slutsatserna och mikroteorin (Kennedy \& Lingard, 2006).

Inledningsvis läste forskarna de intervjuer de genomfört upprepade gånger och resonerade med varandra om vad man iakttagit omkring pedagogiskt arbete. Respektive intervjuomgång kodades efter hand avseende verb som relaterade till pedagogiska handlingar eller avsikter och i fynden jämfördes likheter och skillnader. Gemensamt koncentrerade och kategoriserade forskargruppen verben och diskuterade betydelsen av de situationer de representerade. Analysarbetet höjde abstraktionsnivån, betydelsen av relationerna mellan kategorierna tydliggjordes varur en mikroteori om forskningspersonernas pedagogiska processer formades. För att identifiera betydelsen av hur deltagarna talade om sitt arbete och samspelade med patienter och närstående tolkades dessutom resultaten utifrån praktikgemenskaper och teorier om diskurser.

\section{Analys delarbetet II}

I delarbete II analyserades de individuella intervjuerna och fokusgruppen där läkarna var forskningspersoner. Med utgångspunkt $\mathrm{i}$ de nya forskningsfrågorna läste jag de individuella intervjuerna induktivt i sin helhet upprepade gånger. Däri uppmärksammades aspekter i samspelen som kunde relatera till lärande såväl för läkarna själva som för andra medarbetare, patienter och deras närstående. Intervjutexterna analyserades sedan i NVivo genom att meningsbärande enheter kodades, som refererade till olika utföranden av lärande. Ett exempel är återgivet i tabell 3. De meningsbärande enheterna grupperades i olika teman. Med samma analytiska process bearbetades därefter fokusgruppintervjuerna. De identifierade meningsbärande enheterna jämfördes och kombinerandes med teman från de individuella intervjuerna. Därefter organiserades teman ytterligare i kategorier. 
Tabell 3. Exempel från analysprocessen i delarbete II

\begin{tabular}{|c|c|c|c|}
\hline Meningsbärande enheter (ME) & Kod n=antal ME & Kategori & Huvudkategori \\
\hline$\ldots$ & Fördela dagens arbete, $n=15$ & \multirow{5}{*}{$\begin{array}{l}\text { Planera } \\
\text { arbetsprocedur }\end{array}$} & \multirow{15}{*}{$\begin{array}{l}\text { Läkares lärande i } \\
\text { bearbetnings- och } \\
\text { beslutsprocesser }\end{array}$} \\
\hline $\begin{array}{l}\text { ville jag bara höra dina synpunkter om } \\
\text { patienten på ettan och hur du tyckte vi ska } \\
\text { göra och om hans plan var bra, och så } \\
\text { presenterade han }\end{array}$ & $\begin{array}{l}\text { Planering av enskild patient } \\
\text { medicinska och behov, } 15\end{array}$ & & \\
\hline $\begin{array}{l}\text { då berättade han precis om symptomen om } \\
\text { hur det hade varit och sen så vände han sig } \\
\text { till hon som ska vara på dagvården dagen } \\
\text { efter då }\end{array}$ & $\begin{array}{l}\text { Planering av ansvarsöver- } \\
\text { tagande av patient, } 12\end{array}$ & & \\
\hline $\begin{array}{l}\text { sen pratade } \mathrm{PB} \text { och jag om hur man ger } \\
\text { informationen till den här mamman - att det } \\
\text { blir så många inblandade. }\end{array}$ & $\begin{array}{l}\text { Planering av samtal med } \\
\text { närstående, fyra }\end{array}$ & & \\
\hline $\begin{array}{l}\text { Vissa prylar som vi rengjorde som trans- } \\
\text { fugala xxxx, för att titta på hjärtat och } \\
\text { esofagus det var egentligen doktorerna som } \\
\text { fick lära sig hur man skulle göra det först och } \\
\text { sen fick vi lära ut det till undersköterskorna } \\
\text { som sköter det och nu är det snarare } \\
\text { undersköterskorna som måste säga att man } \\
\text { måste göra på ett visst sätt. }\end{array}$ & $\begin{array}{l}\text { Introduktion av tekniska } \\
\text { hjälpmedel, tre }\end{array}$ & & \\
\hline$\ldots$ & $\begin{array}{l}\text { Läkarmöten för allas } \\
\text { uppdatering, åtta }\end{array}$ & \multirow{2}{*}{$\begin{array}{l}\text { Uppdatering och } \\
\text { kalibrering }\end{array}$} & \\
\hline$\ldots$ & $\begin{array}{l}\text { Patientdata } \mathrm{i} \\
\text { arbetsprocessen, } 17\end{array}$ & & \\
\hline $\begin{array}{l}\text { tittade på henne, hon såg lite, hon såg rätt så } \\
\text { tunn ut upptill på kroppen men rätt så } \\
\text { svullen på under, ja, eh, på under, höfterna } \\
\text { och nedåt, ja så hon hade väl lite högersvikt } \\
\text { eller liknande, men det var ju inget ödem }\end{array}$ & Titta bedöma, 19 & \multirow[t]{3}{*}{ Bedöma patient } & \\
\hline$\ldots$ & Lyssna bedöma, sju & & \\
\hline$\ldots$ & Känna bedöma, åtta & & \\
\hline$\ldots$ & Beslut framtida prognos, sex & \multirow{5}{*}{ Besluta } & \\
\hline $\begin{array}{l}\text { det var någon som hade lite lågt HB som jag } \\
\text { kanske hade, det är typiskt sådan där kanske } \\
\text { jag tänker hjälp, det måste vi nog transfun- } \\
\text { dera medan, då råkade O vara där precis och } \\
\text { då sa han nej vi har is i magen med det. Då } \\
\text { var han trygg i att de där brukar vända, det } \\
\text { är ingen fara att vänta till imorgon, }\end{array}$ & $\begin{array}{l}\text { Titta beslut utredning och } \\
\text { behandling i stunden, attta }\end{array}$ & & \\
\hline$\ldots$ & $\begin{array}{l}\text { Beslut till stöd för andra } \\
\text { professionella, sju }\end{array}$ & & \\
\hline$\ldots$ & $\begin{array}{l}\text { Beslut och delande av } \\
\text { generella utredningsstrate- } \\
\text { gier, tre }\end{array}$ & & \\
\hline $\begin{array}{l}\text { inom vården är det viktigt att ge utrymme } \\
\text { för folk att lära sig... det gör man ju genom } \\
\text { att ge folk ansvar och genom att låta folk } \\
\text { utvecklas, ...det finns en fokusering på att vi } \\
\text { ska gå på utbildningar men det är ju inte där } \\
\text { man kanske egentligen lär sig mest. }\end{array}$ & $\begin{array}{l}\text { Delaktig som underord- } \\
\text { nad läkare i beslut, nio }\end{array}$ & & \\
\hline
\end{tabular}


I det tredje teoridrivna analytiska steget förstärktes det reflexiva analysarbetet genom att de meningsbärande enheterna inom respektive kategori upprepat tolkades genom Kemmis sociomateriella praktikteori (Srivastava \& Hopwood, 2009). Det utgjorde en iterativ analysprocess, med växlande fokus på fynden från data, teorins "säganden", "göranden", materiella arrangemang och "relateranden" i praktiker. Med andra ord arbetade jag utifrån frågorna: 1) Vad säger mig data? 2) Vad vill jag veta mer om? och 3) Vad är det som pågår? Detta gav ett successivt förfinat fokus, förtydligande, samt utmanade relationerna i det som framträdde och fördjupade förståelsen. I den teoridrivna analysen spårades och tolkades läkares lärande och stöd till andras lärande i kulturelltdiskursiva, materiellt-ekonomiska och socialt-politiska arrangemang.

\section{Metod studie B}

I studie II valde jag att studera en specifik hälso- och sjukvårdspraktik, för att ännu mer ingående studera lärande och samspel mellan patienter, läkare och andra vårdgivare. Den valda praktiken var en slutenvårdsavdelning med en relativt nyetablerad rondmodell. Ronden hade etablerats som ett kvalitets- och förbättringsarbete vars syfte var att öka integritet för patienter och stärka deras delaktighet samt utveckla samarbete mellan olika professioner.

\section{Interaktiv forskningsansats med fältstudiedesign}

En interaktiv forskningsansats möjliggör att praktiker och forskare ömsesidigt utvecklar kunskap för att lösa problem som fundamentalt är gemensamma (Aagaard Nielsen \& Svensson, 2006). Något som är särskilt lämpat när sammanhang och problem som studeras är komplexa. Aagaard Nielsen och Svensson (2006) beskriver teori (forskningen) och praktik(vårdsammanhanget) som aspekter av en helhet, komplementära i gemensamt lärande och kritisk kunskapsutveckling. Att inom ramen för interaktiviteten tillämpa en fältstudiedesign, grundad i etnografisk forskningsansats (Hammersley, 2018), möjliggör att ingående kunna studera komplexa reella sammanhang i hälso- och sjukvården (Bunniss \& Kelly, 2010). Centralt i etnografi är att studera vad personer gör och säger i specifika sammanhang. Det genomförs genom att forskaren genomför upprepade deltagande observationer, öppna intervjuer för att få del av personernas egna föreställningar och genom studier av olika dokument som berör praktiken. Essensen i fältstudiedesignen är spänningen mellan ett utifrån-perspektiv genom att observera personer och praktiker och ett inifrån-perspektiv genom att söka förstå personernas egna synsätt 
(Hammersley, 2018). Etnografiska ansatser, med varierande omfattning, betonas som väsentliga för att utveckla fördjupad förståelse för professionella praktiker där samspel och lärande pågår (Hopwood, Day \& Edwards, 2016; Schatzki, 2002)

Genom att tillämpa en interaktiv forskningsansats med fältstudiedesign i studie B kunde betydelsen av existerande och önskade sociomateriella förhållanden (Francisco, Mahon, \& Kemmis, 2017b) spåras i rondpraktikerna. Ellströms modell för interaktiv forskning har varit vägledande i studien (Ellström, 2008). Han beskriver två system, forskningssystemet och praktiksystemet som cykliskt kommer samman för att planera, konceptualisera och tolka forskningsobjektet. Såsom Van de Ven \& Johnson (2006) beskriver den interaktiva forskningsprocessen, var vårdavdelningen (praktiksystemet) både en källa för datainsamling och ett sammanhang för utveckling av idéer och lärande i samspel mellan vårdavdelningens medarbetare och mig som forskare. Genom den bredd av metoder för data-insamling som användes i "fältet", kunde den reella rondpraktiken och deltagarnas föreställningar om denna studeras ingående. I den interaktiva processen var forskarens (min) uppgift att skapa långsiktig, vetenskapligt accepterad teoretisk utveckling, med kontinuerlig tillgång till sitt akademiska sammanhang (Ellström, 2008). Praktikens ledningsteam ansvarade för verksamheten och förändringar i praktiken, som forskare hade jag inte rollen att vara konsult eller förändringsledare. Tillsammans med ledningsteamet tydliggjorde och resonerade jag om ansvarsområden för de två systemen. Därigenom skapades gemensam förståelse och samarbetet befästes i en integrativ process. De problemformuleringar som utvecklades påverkade både val av vissa forskningsmetoder och teoretiska perspektiv som tillämpades i den interaktiva forskningsprocessen.

\section{Sammanhang och deltagare}

Sammanhanget för studien var en slutenvårdsavdelning på en somatisk klinik vid ett svenskt regionsjukhus. Kliniken hade under ett flertal år utvecklat sitt arbetssätt och förbättrat sina vårdresultat genom systematiskt kvalitets- och förbättringsarbete, som beskrivits och studerats med vetenskapliga metoder (Porter, Baron, \& Rejler, 2011; Rejler, Spangeus, Tholstrup, \& Andersson-Gare, 2007; Rejler, Tholstrup, Elg, Spångéus, \& Gäre, 2012; Thörne, Andersson-Gäre, Hult, \& AbrandtDahlgren, 2017).

Den aktuella vårdsavdelningen kunde ta emot 16 patienter, som fördelades på tre vårdlag bestående av sjuksköterskor och undersköterskor. Vårdavdelningens sjuksköterskor och undersköterskor 
bemannande den ständigt, dag som natt och därmed varierade det vilka personer som ingick i vårdlagen. Stationärt på vårdavdelningen fanns också vårdadministratörer (medicinska sekreterare) medan arbetsterapeut, fysioterapeut, dietist och kurator hade konsultativa arbetssätt, dvs. de kom för specifika patientuppdrag och delades med andra vårdenheter. Vårdavdelningens fyra specialistläkare var ansvariga en vecka i taget och hade samtidigt sitt arbete förlagt till avdelningen såväl som till en öppenvårdsenhet och en specialenhet. Klinikens AT- och ST-läkare (underläkargruppen) och sidotjänstgörande ST-läkare från andra specialiteter, roterade mellan klinikens vårdenheter och akutverksamheten beroende på de dagliga behoven av arbetsinsatser och deras mål i respektive utbildningstjänstgöring.

På vårdenheten genomförde framförallt sjuksköterske-, undersköterske- och läkarstudenter regelbundet verksamhetsförlagd utbildning (VFU). Klinikens VFU-ansvariga och studierektorer för SToch AT-läkare ansvarade för organisering och övergripande kvalitet för respektive grupper, de arbetade inte på den aktuella vårdavdelningen.

\section{Datainsamling i den interaktiva processen}

I den interaktiva processen ingick förberedande fältarbete och flera interaktiva faser varvat med fältarbete (tabell 5). Dessutom löpte analysarbetet parallellt som beskrivs i nästa avsnitt. I det förberedande fältarbetet fördes kontinuerliga samtal med vårdenhetens ledningsteam om vad som var relevant att studera utifrån samspel och lärande både för vårdenheten och $\mathrm{i}$ forskningen. Studier av dokument, deltagande observationer på och utanför vårdavdelningen (morgonmötet för hela läkargruppen) samt informella samtal med sex personer utanför vårdavdelningen med olika funktioner relevanta för studien, utgjorde datakällorna i förberedelsefasen. Bredden av datakällor i fältstudiedesignen motiverades ytterligare av att deltagare $i$ en praktik tenderar att ta kritiska aspekter i sina aktiviteter för givna (Suchman, 1995) och att i intervjuer utelämna sådant de betraktar som basalt (Nicolini \& Monteiro, 2016). Tillsammans med ledningsteamet beslutades att ronden skulle vara fokus för studien. Den planerade studiedesignen presenterades och diskuterades med vårdavdelningens medarbetare (inklusive de forskningsetiska ramarna), vilket gav förankring och grund för fortsatt samarbete.

Den interaktiva forskningsansatsen med fältstudiedesign beskrivs i tabell 4. I kolumnerna presenteras; först de principiella stegen i den interaktiva 
processen, därefter vilka forskningsmetoder som tillämpades, följt av bredden av forskningspersoner som deltog samt andra data-källor.

Tabell 4. Metod, deltagare, data och analyser i den interaktiva ansatsen med fältstudiedesign

\begin{tabular}{|c|c|c|c|}
\hline $\begin{array}{l}\text { Interaktion } \\
\text { över tid }\end{array}$ & Metoder & Datakällor & $\begin{array}{l}\text { Analyser genom- } \\
\text { förda av forskaren }\end{array}$ \\
\hline $\begin{array}{l}\text { Förberedande } \\
\text { fältarbete }\end{array}$ & $\begin{array}{l}\text { Informella samtal } \\
\text { Deltagande } \\
\text { observationer } \\
\text { Dokument }\end{array}$ & $\begin{array}{l}\text { Avdelningens ledningsteam } \\
\text { Andra signifikanta personer } \\
\text { Arbetsplatsträff } \\
\text { Morgonrond } \\
\text { Läkarnas morgonmöte } \\
\text { Publikationer om enheten } \\
\text { Utvärdering av } \\
\text { rondmodellen }\end{array}$ & $\begin{array}{l}\text { Preliminära analyser } \\
\text { av fältanteckningar } \\
\text { och dokument }\end{array}$ \\
\hline Interaktiv fas 1 & $\begin{array}{l}\text { Design av studien } \\
\text { Presentation av } \\
\text { studiens design }\end{array}$ & $\begin{array}{l}\text { Ledningsteamet } \\
\text { All personal }\end{array}$ & $\begin{array}{l}\text { Utveckling av } \\
\text { studiedesign }\end{array}$ \\
\hline $\begin{array}{l}\text { Steg } 1 \\
\text { fältarbete }\end{array}$ & $\begin{array}{l}\text { Observationer, } \\
\text { bandinspelade, } \\
\text { transkriberade } \\
\text { Deltagande } \\
\text { observationer }\end{array}$ & $\begin{array}{l}\text { Morgonronder }(\mathrm{n}=\mathrm{fem}) \\
\text { med patienter från de tre } \\
\text { vårdlagen } \\
\text { Avdelningens utvecklings- } \\
\text { dag: } \\
\text { all personal på enheten }\end{array}$ & $\begin{array}{l}\text { Induktiv tematisk } \\
\text { analys av samspel } \\
\text { och lärande i } \\
\text { morgonronderna. } \\
\text { Första utformning } \\
\text { av modell i figur } 5 \\
\text { baserat på dittills } \\
\text { insamlad data }\end{array}$ \\
\hline Interaktiv fas 2 & $\begin{array}{l}\text { Lärandeseminarium: } \\
\text { presentation, } \\
\text { diskussion av } \\
\text { preliminära fynd }\end{array}$ & $\begin{array}{l}\text { Ledningsteamet } \\
\text { All personal }\end{array}$ & $\begin{array}{l}\text { Specificering av } \\
\text { forskningsfrågor } \\
\text { och studiedesign }\end{array}$ \\
\hline $\begin{array}{l}\text { Steg } 2 \\
\text { fältarbete }\end{array}$ & $\begin{array}{l}\text { Gruppintervjuer*, } \\
\text { intervju guide } \\
\text { baserad på } \\
\text { preliminära fynd: } \\
\text { frågor om egna och } \\
\text { andra professioners } \\
\text { arbete och lärande } \\
\text { inklusive preliminär } \\
\text { modell (fig 5). }\end{array}$ & $\begin{array}{l}\text { Professionsgrupper: } \\
\text { - underläkare som jobbat } \\
\text { på avdelningen (sex) } \\
\text { - specialistläkare (fyra, en } \\
\text { individuell intervju) } \\
\text { - sjuksköterskor (fyra) } \\
\text { - undersköterskor (tre) }\end{array}$ & $\begin{array}{l}\text { Induktiv tematiska } \\
\text { analys av samspel } \\
\text { och lärande i } \\
\text { rondarbete, } \\
\text { professioners } \\
\text { funktioner samt } \\
\text { revidering av figur } 5\end{array}$ \\
\hline Interaktiv fas 3 & $\begin{array}{l}\text { Informella samtal } \\
\text { om preliminära } \\
\text { fynd }\end{array}$ & $\begin{array}{l}\text { Ledningsteam } \\
\text { Specialistläkare (fyra) } \\
\text { Annan personal }\end{array}$ & \\
\hline $\begin{array}{l}\text { Steg } 3 \\
\text { avslutande } \\
\text { forsknings- } \\
\text { process för } \\
\text { delarbete III } \\
\text { och därefter } \\
\text { delarbete IV }\end{array}$ & & All insamlad data & $\begin{array}{l}\text { Analyserande } \\
\text { genom de praktik- } \\
\text { teoretiska linserna }\end{array}$ \\
\hline
\end{tabular}


Slutligen en kolumn som sammanfattar analysarbetet. Genom att läsa tabellen horisontellt tydliggörs interaktiviteten i varje steg av fältarbetet, med metoder, datakällor, analyser och utvecklingen av forskningsdesignen.

De fem ronderna som observerades varade mellan 2 och 2.5 timmar. Vid varje rond deltog de tre vårdlagen ett och ett med sina aktuella patienter. En patient i taget var där tillsammans med sjuksköterska och undersköterska från sitt vårdlag. En överläkare och en underläkare deltog i regel i hela ronden, men det var olika läkare som deltog i de studerade ronderna. I en rond deltog också en sjuksköterskestudent.

Patienterna fick skriftlig och muntlig information om studien av sin sjuksköterska. En patient ville inte delta i studien, jag lämnade då rondrummet tillfälligt. Några patienter kunde av hälsoskäl inte komma till rondrummet. Teamet diskuterade då dessa patienters situation i deras frånvaro och besökte dem efter ronden.

Vid lärandeseminariet under interaktivitet 1 (tabell 5) presenterades och diskuterandes preliminära fynd från rondobservationerna med avdelningens medarbetare. De identifierade aspekterna om samspel och lärande skapade intresse. Och frågor väcktes omkring hur olika professionerna såg på och hade förväntningar på egna och varandras roller.

Tillsammans med ledningsteamet beslutades att nästa fältarbete skulle bestå av gruppintervjuer med respektive professionsgrupp, där läkarna delades in i specialistläkare respektive underläkare på kliniken. Utifrån de preliminära fynden från rondobservationerna togs en intervjuguide fram. De preliminära fynden från gruppintervjuerna återkopplades med ledningsteamet och med avdelningens specialistläkare. Ledningsteamet genomförde återkopplingen till avdelningens övriga professioner.

\section{Analyser i den interaktiva processen}

Det förberedande fältarbetet med efterföljande analyser innebar att som utomstående forskare bilda sig en uppfattning om avdelningen och andra sammanhang som hade relevans för samspel och lärande på vårdavdelningen. Analyserna utgjorde underlag för resonemang med ledningsteamet och designen av studien i nästa steg.

De observerade och bandinspelade ronderna analyserades genom att jag inledningsvis lyssnade på och transkriberade inspelningarna. Därefter följde en induktivt tematisk analys där meningsbärande enheter som rörde samspel och lärande kodades, koncentrerades och kategoriserades i verktyget NVivo. Betydelsen av sammanhangen framstod tydligt och utifrån fynden formade jag en första schematisk bild över avdelningens 
olika rum, funktioner och hur patienter och olika professionsgrupper rörde sig mellan dessa under en arbetsdag.

Gruppintervjuerna från andra fältstudiefasen transkriberades och analyserades induktivt tematiskt på motsvarande sätt som observationerna av ronderna. Förutom interaktion och lärande tillkom två nya teman: egna och andras funktioner eller roller.

Tabell 5. Summering av metoderna i de två delarbetena i Studie B

\begin{tabular}{|c|c|c|}
\hline & \multicolumn{2}{|c|}{ Studie B interaktiv forskningsansats med fältstudiedesign } \\
\hline & Delarbete III & Delarbete IV \\
\hline $\begin{array}{l}\text { Specifikt } \\
\text { syfte }\end{array}$ & $\begin{array}{l}\text { Öka förståelsen för praktiska } \\
\text { aspekter i ny modell för att } \\
\text { genomföra ronder }\end{array}$ & $\begin{array}{l}\text { Fördjupa förståelsen av arrange- } \\
\text { mang för underläkarens lärande i } \\
\text { en specifik arbetssituation. } \\
\text { Underläkarnas praktik i } \\
\text { rondarbete utgör inramningen }\end{array}$ \\
\hline $\begin{array}{l}\text { Forsknings- } \\
\text { fråga }\end{array}$ & $\begin{array}{l}\text { Hur påverkar materiella och } \\
\text { sociala förhållande i en specifik } \\
\text { hälso- och sjukvårdspraktik } \\
\text { samspelet mellan dess deltagare? }\end{array}$ & $\begin{array}{l}\text { Vilka praktiker är underläkare } \\
\text { engagerade i? Hur möjiliggör } \\
\text { dessa praktiker underläkares } \\
\text { lärande? }\end{array}$ \\
\hline $\begin{array}{l}\text { Studiens } \\
\text { deltagare } \\
\text { och } \\
\text { situationer }\end{array}$ & $\begin{array}{l}\text { Rondpraktiker med patienter, } \\
\text { läkare, sjuksköterskor, underskö- } \\
\text { terskor och underläkare, därtill } \\
\text { vårdenhetens ledning och andra } \\
\text { relevanta personer på kliniken }\end{array}$ & $\begin{array}{l}\text { Underläkarpraktiken i relation till } \\
\text { patienter, andra professionella } \\
\text { praktiker och materiella förhål- } \\
\text { landen på en vårdavdelning }\end{array}$ \\
\hline \multirow[t]{2}{*}{ Dataanalys } & \multicolumn{2}{|c|}{$\begin{array}{l}\text { Induktiva tematisk analys i två steg alternerat med datainsamling. NVivo. } \\
\text { Preliminära fynd i steg } 1 \text { var underlag till gruppintervjuer i steg } 2\end{array}$} \\
\hline & $\begin{array}{l}\text { Avslutande teoridriven analys då } \\
\text { all data tolkades både genom } \\
\text { perspektivet kliniska mikrosys- } \\
\text { tem och sociomateriell } \\
\text { praktikteori }\end{array}$ & $\begin{array}{l}\text { Avslutande teoridriven analys } \\
\text { med sociomateriell praktikteori }\end{array}$ \\
\hline $\begin{array}{l}\text { Teoretiska } \\
\text { ramar }\end{array}$ & $\begin{array}{l}\text { Praktikarkitekturer, sociomate- } \\
\text { riellt praktikteoretiskt perspektiv }\end{array}$ & $\begin{array}{l}\text { Praktikers ekologier, sociomate- } \\
\text { riellt praktikteoretiskt perspektiv }\end{array}$ \\
\hline
\end{tabular}

\section{Avslutande analys delarbete III}

Med utgångspunkt i forskningsfrågan (tabell 6) genomfördes en avslutande teoridriven analys av alla insamlade data och prelimära fynd. Den tillämpade kombinationen av tematisk induktiv och teoridriven analys utgår från Srivastava och Hopwood (2009) metod och är mer utförligt beskriven i delarbete II. I analysen identifierandes materiella förhållanden, sägande, görande och relaterande som var av betydelse för rondpraktikerna. De tolkades genom både perspektivet kliniska mikrosystem och Kemmis sociomateriella praktikteoretiska perspektiv och praktikarkitekturer. Analysprocessen var liksom vid delarbete II 
iterativ och reflexiv. Härigenom tydliggjordes hur sociala och materiella arrangemang prefigurerade utformningen av ronderna.

Delar av fynden i delarbete III väckte frågor omkring underläkarna i rondpraktiken, vilket innebar att studie $\mathrm{B}$ genererade ett ytterligare delarbete, (IV).

\section{Avslutande analys delarbete IV}

Delarbete IV byggde på samma data och preliminära analyser från den interaktiva forskningsprocessen som delarbete III. Fokus var här hur underläkare arbetade och lärde i ronderna inkluderat för- och efterarbete. Då samspelen med andra professionsgrupper och patienter verkade ha påtaglig betydelse, utgjorde praktikers ekologier (Kemmis et al., 2012) det teoretiska redskapet i den tematiska och interaktiva analysprocessen, beskriven under delarbete II (Srivastava \& Hopwood, 2009). Därigenom identifierades konkreta uttryckssätt, aktiviteter, sätt att relatera samt materiella arrangemang som var relevanta för underläkarnas praktik och lärande. Genom den teoridrivna analysen kunde jag identifiera sociomateriella arrangemang som prefigurerade underläkarnas praktik och lärande format i sammankopplingar med andra professionspraktiker, patienter och materiella arrangemang.

\section{Etiska överväganden}

Båda studierna i avhandlingen, presentationerna i delarbetena, forskningsprocessen och förvaringen av data har följt nationella och internationella etiska riktlinjer för forskning som involverar personer (SFS 2003:460). Vid tiden för den första studien, vars deltagare var vårdgivare i flera professioner men inga patienter, fanns inte krav på formell etikansökan. Den andra studien var godkänd av den regionala etikprövningsnämnden i Linköping (Dnr. 11-09).

I studie A angavs i informationsbrevet till deltagarna och deras chefer att deltagande var frivilligt och att deltagarna kunde avbryta sin medverkan utan att behöva ange skäl därtill. Budskapet upprepades muntligen i samband med intervjuerna, liksom informationen om att dokumenterat intervjumaterial avidentifierades och förvarades säkert.

I studie $\mathrm{B}$, som byggde på en interaktiv ansats med fältstudiedesign var processen för att utveckla ett acceptabelt etiskt forskningssammanhang mer komplex. Denna ansats innebär att man som forskare befinner sig i pågående praktiker och därmed i skeenden som inte är helt förutsägbara. 
Deltagarna ger sitt medgivande till forskarens närvaro, men det är inte lika avgränsat som till exempel en intervju. Det vägs upp av att forskaren kan etablera förtroendefulla sammanhang, med möjlighet för den enskilde deltagaren att i specifika situationer avlägsna sig utan motivation. I den interaktiva processen har deltagaren möjlighet att både ta del av fynd och tolkningar av dem och ge återkoppling eller addera mer information.

Valet av den studerade vårdenheten gjordes genom forskningsprojektet "Bridging the Gaps" som studien var en del av. Verksamhetschefen och vårdenhetens ledningsteam godkände genomförandet av studien och de senare var dessutom engagerade i den interaktiva processen. I det förberedande fältarbetet ingick för mig som forskare att bygga förtroende och samsyn med ledningsteamet omkring vad som skulle studeras. Och med avdelningens medarbetare för att kunna delta på avdelningen och få tillgång de autentiska praktikerna. I det förberedande fältarbetet ingick skriftlig information om studien, frivillighet och konfidentialitet. Därutöver genomfördes ett muntligt informationsmöte om studiens design tillsammans med ledningsteamet.

Ledningsteamet instruerade avdelningens sjuksköterskor om hur de skulle förmedla information om studien till aktuella patienter. Ett speciellt informationsbrev utformades om studien, inkluderande information om frivillighet att delta, riktat till patienterna $\mathrm{i}$ de observerade ronderna. De patienter som var aktuella i ronderna som observerades, fick på morgonen samma dag både den skriftliga och muntliga informationen om studien av sin sjuksköterska.

Deltagarna i gruppintervjuerna utsågs av ledningsteamet, förutom underläkarna som utsågs av klinikens studierektor för AT- och ST-läkare. Dessa deltagare fick skriftlig och muntlig information med motsvarande information som övriga grupper före, respektive i samband med, intervjuerna. 


\section{FYND}

I detta kapitel görs en sammanfattning av de mest centrala fynden i de två delstudierna, där varje delarbete presenteras separat. Först presenteras fynden i intervjustudien (delarbete I och II) och därefter den interaktiva fältstudien (artikel III och IV).

\section{Pedagogiska processer i hälso- och sjukvården:}

En utforskande studie om pedagogiskt arbete med patienter och närstående (I)

I det medicinska, omvårdande och rehabiliterande arbete som läkare, arbetsterapeuter och sjuksköterskor genomför med patienter och deras anhöriga finns pedagogiska processer inbäddade. Generellt kan pedagogiska processer i uttalade utbildningssituationer beskrivas som linjära, med en tydlig inledning och ett avslut. De innefattar planering, målsättning, undervisning och utvärdering. Studien visade att de vanligt förekommande pedagogiska processerna i hälso- och sjukvårdens dagliga arbete ofta hade oklara inledningar och avslut och genomfördes i rum som i regel inte var arrangerade för pedagogiskt arbete. Principen för en pedagogisk process i hälso- och sjukvårdsarbete kunde sammanfattas i konceptet: avläsa-färdrikta- lärstödja. De verb som informanterna använde i sina beskrivningar av vårdarbetet och som visade på pedagogiska avsikter indikerade att vårdgivarna läste av situationer genom att till exempel undersöka och utforska. De färdriktade genom att till exempel prioritera och influera snarare än att sätta upp tydliga mål och de stöttade lärandet. Exempel på lärstödjande handlingar var att demonstrera, informera, förklara och instruera. Då vårdgivarnas lärstödjande arbete var inbäddat i medicinskt, omvårdande och rehabiliterande arbete var målen för de arbetsuppgifterna i förgrunden och varken mål eller utvärdering av stödet för lärande var tydliga.

Det pedagogiska arbete som ofta genomfördes framstod som oplanerat, oreflekterat och det framkom inte heller att man resonerade omkring det med arbetskamrater. Deltagandet i studien väckte däremot medvetenhet om behov av utveckling av pedagogiska handlingssätt för att kunna stödja andras lärande. 


\section{Dynamiken i läkares lärande och stöd till andras lärande (II)}

Läkares betydelse vid både andras och eget lärande i vårdarbetet analyserades genom ett sociomateriellt praktikteoretiskt perspektiv av intervjuerna i studie A (specialister och ST-läkare från sju specialiteter deltog). Det tydliggjorde att läkare, med eller utan intentioner, stöttade patienters och deras närståendes lärande. Deras agerande stöttade också lärandet för läkarkollegor och för medarbetare i andra professioner. Samtidigt tydliggjordes flera dimensioner av läkares eget lärande i deras medicinska praktiker. Sammantaget framträdde läkarnas lärande och stöd till andras lärande genom hur de uttryckte sig (sägande), vad de gjorde (görande) och hur de relaterande till andra (relaterande) i olika rum (undersökningsrum, expedition, operationssal, korridor) och vid användandet av olika redskap (datorer, texter, undersökningsinstrument, operationsutrustning). I läkarnas beskrivningar identifierades fyra kategorier inom vilka eget lärande och stöd till andras lärande kunde urskiljas:

- (a) individuella patientprocesser, dvs. allt agerande och samarbete för och med enskilda patienter,

- (b) mångsidig mobilitet mellan olika sammanhang,

- (c) samarbete i ett flertal varaktiga grupper och

- (d) spänningar mellan olika professionella ansvarstaganden.

(a) Läkarnas huvudsakliga mål och engagemang var att genomföra medicinsk vård med god kvalitet $i$ de individuella patientprocesserna. Däri framträdde lärande och lärstödjande som inte var artikulerat med pedagogiska avsikter, medan sådant som var intentionellt framträdde begränsat och varierade mellan olika discipliner. Ett exempel var läkarnas lärande när de omsatte generell medicinsk kunskap i samspel med enskilda patienter och i samspelet fördjupade förståelsen för den enskilda patientens levda erfarenheter av symptom och sjukdomar och konsekvenserna av dessa. Vid undersökningar och behandlingsarbete använde läkarna olika instrument och den egna kroppen (auditivt, visuellt och taktilt) som redskap, vilket bidrog till deras förståelse och utveckling av färdigheter. Det fanns stora variationer av sätt att lärstödja patienter och närstående, vanligast var lämnande av information. Exempel fanns också på hur patienter i kretsen av vårdgivare "styrde" sin egen vård. Interaktionen med andra professioner varierade från enkel informationsöverföring till interprofessionellt samarbete, vilket bidrog till olika typer av lärande för alla inblandade i de olika sammanhangen. Kollegialt stöd mellan läkare, inklusive 
handledningsstöd var också av betydelse för lärandet i de individuella patientprocesserna.

(b) Alla läkarna beskrev hur de på olika sätt hela tiden var mobila, de rörde sig emellan olika sammanhang i hälso- och sjukvården. Mobiliteten, betraktat som ett sociomateriellt arrangemang, möjliggjorde lärande genom den variation som uppstod och genom läkarnas jämförande mellan olika arbetsgrupper, olika arbetsuppgifter, fysiska och virtuella sammanhang.

Läkarna rörde sig mellan flera olika arbetsgrupper som hade olika uppgifter, olika materiella förutsättningar och vars deltagare hade olika sätt att relatera till varandra. Att läkarna deltog i ett flertal grupper medförde att grupperna kontrasterades mot varandra, vilket skapade variation och prefigurerade lärande för dem och för andra de interagerade med i arbetsgrupperna.

Mobilitet som stärkte lärandet förekom vidare genom läkarnas olika typer av arbetsuppgifter som genererade en bredd av erfarenheter inom och utanför individuella patientprocesser. Exempel på det var konsultativa patientrelaterade uppdrag på andra kliniker och äldreboenden, ledningsmöten, utbildnings- eller utvecklingsuppdrag och kollegial träning av praktiska färdigheter.

Läkarnas fysiska och virtuella (telefon och IT) mobilitet inom och utanför de sjukvårdsinrättningar de tillhörde, genererade varierande erfarenheter och lärande. Förutom exempel på fysisk mobilitet som redan nämnts kunde en enskild läkare dagligen röra sig mellan mottagning, vårdavdelning, operation och akutavdelning. Virtuell mobilitet förkom genom telefonkonsultation av kollegor i annan del av landet eller internationellt för att därigenom ge eller få stöd i medicinska uppgifter.

(c) Alla läkarna deltog i ett flertal grupper regelbundet, som hade olika uppgifter och befann sig i olika fysiska miljöer. I grupperna byggde deltagarna samarbete, kunnande och kapacitet för att genomföra hälsooch sjukvårdsarbete av god kvalitet. Med variation för olika discipliner förekom det kollegialt stöd och samarbete i disciplinära och tvärdisciplinära läkargrupper och i interprofessionella team eller team som involverade patienter. I dessa praktiksamarbeten var lärande och stöd till andras lärande för både professionella och patienter sammanvävt och iscensattes i varierande grad.

(d) Alla läkarna betonade vikten av ansvarstagande i den medicinska praktiken för att utveckla sitt kunnande. Olika typer av ansvar påverkade läkarnas förståelse, agerande och sociala relaterande i det dagliga arbetet och som därigenom skapade spänningar som utgjorde källor för lärande och lärstödjande. Först spänningen mellan att för läkarna ge och ta på sig ansvar i olika typer av uppgifter. Vidare 
spänningar som uppkom genom ansvaret att självständigt fatta beslut eller att göra det med stöd av någon annan. Slutligen spänningar mellan att agera för att uppdatera medicinska standarder och genomföra förbättringar i vården, och att ta del av och använda resultaten av sådant arbete i större grupper.

I delarbete II har dynamiken och komplexiteten i möjligheter och begränsningar för läkares lärande och stöd till andras lärande i dagligt hälso- och sjukvårdsarbete tydliggjorts. Fynden inom de fyra kategorierna indikerade att olika medicinska discipliner hade varierande extraindividuella förhållanden, sammanfogade med specifikt sägande, görande, materiella arrangemang och sätt att socialt relatera. I varje hälso- och sjukvårdspraktik utgjorde de sammanfogade arrangemangen specifika praktikarkitekturer som prefigurerade såväl praktiken som läkares lärande och lärstödjande agerande däri.

\section{Samskapat interprofessionellt rondarbete: Att designa rum för partnerskap med patienter (III)}

I den relativt nyinförda rondmodell som studerades i delarbete III, framträdde både lärande rondande och operativt rondande.

Allt rondande hade förändringar i praktikarkitekturerna bestående av ett specifikt rondrum (materiellt arrangemang) dit en patient i taget kom med sin undersköterska (ekonomiskt och socialt arrangemang i form av ny deltagare). De deltog i rondandet med sjuksköterskan från sitt vårdlag och med överläkare och aktuell underläkare. I rondrummet satt alla deltagare på ett jämbördigt sätt i en cirkel runt ett bord och alla hade ögonkontakt med varandra (materiellt arrangemang). Två datorskärmar som visade relevant information om varje patient (materiellt arrangemang) ingick i kretsen av deltagare runt bordet.

I ronderna deltog patienterna som aktörer på två olika sätt, genom sitt personliga deltagande och genom sin på bildskärmarna exponerade journal. Det innebar att de kunde vara aktiva deltagare med sina perspektiv och frågor i samspel med vårdgivarna (diskursiva och sociala arrangemang). Samtidigt presenterades och justerades deras individuella data om deras sjukdom, undersökningsresultat och behandling i journalen på skärmarna (materiella arrangemang) synligt för alla deltagare. Hur patienterna som personer deltog i rondandet var ett förhållande som påverkande om rondandet framträdde som lärande eller operativt. 
Patienternas aktiva deltagande som personer underlättades av de beskrivna materiella arrangemangen. Det skapade integritet genom att bara en deltagande patient i taget fanns i rondrummet och det signalerade patienternas betydelse $\mathrm{i}$ rondandet genom att patienter och vårdgivare hade likvärdiga positioner (sociala arrangemang). Också relationella och diskursiva förhållanden i praktikarkitekturen stärkte patienternas aktiva deltagande; till exempel genom att undersköterskorna som träffade patienterna i den dagliga omvårdnaden stöttande deltog i ronderna. Vidare att sjuksköterskorna uppmuntrade patienterna att tala för sig själva, istället för att ta över och prata för patienterna såsom de sa att de brukade göra i bed-side-ronderna. Patienternas aktiva deltagande underlättades av att överläkarna bjöd in dem till samtal, anpassade både verbalt och icke verbalt språk och respektfullt svarade på deras frågor med möjlighet till andra deltagares involvering. På så sätt utgjorde ronden ett specifikt socialt-politiskt arrangemang som prefigurerade patienternas aktiva deltagande.

Det andra sättet varpå patienterna agerade i ronderna var genom journalinformationen, som framträdde då underläkarna löpande kalibrerade och uppdaterade informationen på datorskärmarna. Skärmarna formades härigenom till aktiva deltagare med positioner vid bordet som interagerade med övriga deltagare. På så sätt blev patienternas deltagande dubbelt och alla vårdgivare fick samtidigt samma information att ta ställning till och ytterligare möjligheter att bearbeta. Ur detta kom det som utvecklade sig och beslutades i rondandet. Det underlättade deltagarnas gemensamma förståelse av sjukdomstillstånd, vad det betydde för den unika patienten och för hur var och en skulle agera i sina specifika uppgifter efter ronden.

Ronden utvecklades som ett kliniskt mikrosystem utifrån uppsatta mål genom att bättre möta patienternas behov och behovet av samverkan mellan professioner. Utöver de förändringar som var planerade prefigurerade rondens praktikarkitektur också lärande och utveckling av kunnande såväl för patienter som för vårdgivare i de deltagande professionerna. Det framträdde genom deras sätt att förstå, agera och relatera till varandra och skärmarna under samtal, bedömning, planering och beslut rörande varje patient. När patienterna aktivt delade perspektiv och frågor blev de mer eller mindre samskapare med vårdgivarna $\mathrm{i}$ rondandet. Vårdgivarna iakttog såväl patienternas som varandras agerande och bidrog med olika kunskaper och erfarenheter, vilket blev källor för lärande för andra deltagare (diskursiva och sociala arrangemang). Vårdgivarna uppskattade det nya sättet att ronda och 
menade att man på så sätt bättre kom till kärnan av patienternas problem. Enligt dem ställde patienterna färre frågor efter ronderna, vilket talade för att patienterna fick svar på de frågor de hade.

Trots de varaktigt förändrade materiellt-ekonomiska arrangemangen i ronderna, framträdde återkommande operativt rondande. Detta rondande var inte format av enskilda vårdgivare, utan prefigurerat av socio-politiska och kulturellt-diskursiva arrangemang överförda från det traditionella bed-side rondandet. I operativt rondande kunde överläkarna ha förarbetat och fattat preliminära beslut före ronden för att i ronden enbart bekräfta dessa beslut. Sjuksköterskor kunde också undanhålla information som skulle kunna ha betydelse för interaktionen i ronden och utfallet av vården. Rondandet dominerades av den medicinska handläggningen, medan omvårdande perspektiv mer sällan trädde fram. Övriga vårdgivare anpassade sitt agerande till överläkarnas förhållningssätt och ageranden. Patienterna var i det operativa rondandet i periferin och framstod som passiva mottagare av bedömningar och beslut (socialt-politiskt arrangemang). Samarbete och gemensam problemlösning begränsades, och därmed också lärandet för alla deltagare.

Enskilda vårdgivare deltog och agerade både i lärande rondande och $\mathrm{i}$ operativt rondande i det dagliga arbetet. Från dag till dag varierade det vilka personer som deltog i ronderna från de olika professionsgrupperna. Det medförde att enskilda vårdgivare interagerade med och iakttog hur ett flertal vårdgivare i andra professioner interagerade i rondandet, men däremot inte personer i den egna professionsgruppen. Det skapade för dem förståelse för skillnader i sättet att ronda och för hur attityder, agerande och relaterande påverkade rondandet. Trots det hade de inte makt att som enskilda personer förändra det som uppstod i de operativa ronderna och som inte överensstämde med gemensamt beslutade intentioner med rondmodellen.

\section{Lärande i arbetet: Ekologiska sammankopplingar i underläkares hälso- och sjukvårdspraktiker (IV)}

Delarbete IV fokuserade särskilt på underläkares deltagande i rondandet och det för- och efterarbete som genomfördes. Det baserades på hur underläkares uttalanden, ageranden och sociala samspel var sammanvävt och formades av överläkares, sjuksköterskors, undersköterskors, 
vårdadministratörers (det vill säga olika professionspraktiker) uttalanden, ageranden och relateranden och också av patienters. Rondarbete tillsammans med andra uppgifter utfördes i olika rum på vårdavdelningen. Nedanstående figur (figur 5) illustrerar en arbetsdag schematiskt, med de rum som olika professionspraktiker interagerade i och förflyttade sig mellan. Figuren tydliggör var och när professionspraktikerna och/eller patienterna var sammankopplade och var professionerna utförde sina arbetsuppgifter enskilt.

Morgonronden var ett tydligt tillfälle där vårdgivare i de flesta professionsgrupperna kopplades samman i samma rum och delade erfarenheter, information och kunnande med en patient i taget omkring dennes utredning, behandling och vård. Därigenom utgjorde morgonronden ett nätverkande som upprepades cykliskt varje dag. I nätverkandet bidrog deltagarna ömsesidigt till varandras förutsättningar att komma vidare i sina olika uppgifter för och med patienterna efter ronden.

Underläkarna var en av de deltagande professionsgrupperna i detta nätverkande. Figur 5 visar schematiskt hur och var kopplingarna mellan

Figur 5. Schematisk illustration av hur patienters och olika professionspraktikers sammankopplingar framträder under en arbetsdag.

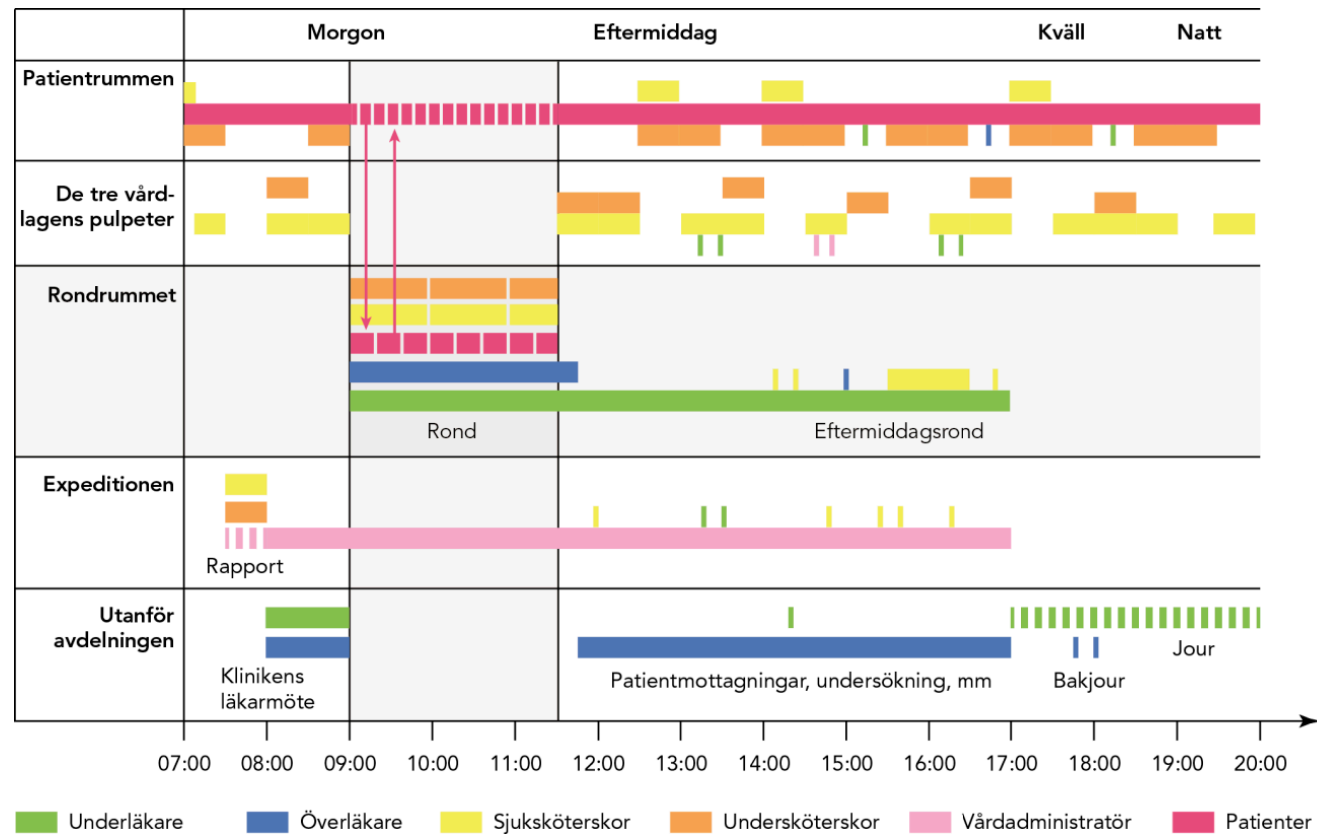


underläkarpraktiken, de andra professionspraktikerna och med patienterna framträdde under dagen. Fem funktioner som tydliggör ekologin mellan de olika praktikerna och de förutsättningar för underläkares lärande som prefigurerades i rondandet kan beskrivas på följande sätt:

1. Underläkarna observerade patienters och andra professionsgruppers interageranden i morgonronderna (fig. 5). Deras förståelse för både innehåll i rondandet och för olika professionsgruppers arbete formades av hur dessa uttryckte sig, agerade och samarbetade. När patienterna var aktiva både fysiskt och genom att de uttryckte sitt perspektiv på sin situation, bidrog det till att underläkarna kunde kontextualisera teoretiska medicinska kunskaper genom patienters levda erfarenheter. Klinikens olika avdelningar utgjorde system som var inkapslade i varandra, då underläkarna kontinuerligt roterade mellan dem och därmed kunde jämföra rondande mellan olika avdelningar. Underläkarna noterade både sådant som de ansåg vara bra och dåligt rondande. Det gav grund för reflektioner som potentierade underläkarnas individuella lärande, men de bearbetade inte dessa reflektioner med andra. I sammankopplingarna med andra professionspraktiker och patienter framträdde underläkarnas lärande genom fokuserade observationer och egna reflektioner, men inte genom eget agerande.

2. Underläkarna monitorerade och administrerade patientdata löpande under rondandet. De texter de formulerade för journalen och hanteringen av informationsteknologin gav dem ett ansvarsområde och bidrog till deras lärande. Därigenom fick också alla deltagare samma information samtidigt och andra professionsgruppers rondarbete underlättades eller fullföljdes. Men underläkarna skulle under tidspress samtidigt observera, monitorera och dokumentera det som skedde runt varje patient i rondandet. Det medförde att deras uppmärksamhet splittrades och de kunde missa information eller inte fånga innebörden $\mathrm{i}$ det som till exempel beslutades. Synsättet i klinikens överläkarpraktik var att korta ronder var bra ronder. Överläkarpraktiken kapslade därmed in den underordnade och beroende underläkarpraktiken i tidspress. Denna tidspress medförde att underläkarna individuellt fick söka strategier för att kunna hantera det administrativa uppdraget under och efter ronden.

Under resterande tid av arbetsdagen innebar underläkarpraktiken administrativt patientarbete samt att vara tillgänglig läkare på avdelningen. Detta arbete utfördes tidmässigt till största del som ensamarbete $\mathrm{i}$ rondrummet (fig. 5). $\AA$ ena sidan innebar det administrativa patientarbetet och tillgängligheten på avdelningen ett ansvar och ett förtroende. $\AA$ andra sidan innebar det begränsade möjligheter att i interaktion med mer erfarna läkare föra medicinska 
resonemang som både kunde fördjupa och kalibrera lärandet centralt i deras yrkesutövning. Underläkarnas administrativa arbete prioriterades av andra professioner och förutsättningar för deras lärande fick stå tillbaka.

3. Underläkarna hade minimal egen interaktion med patienterna som personer, trots att de själva önskade det motsatta. De relationella intersubjektiva rummen för interaktion med patienter dominerades av överläkarna under morgonronderna och av undersköterskor och sjuksköterskor i patientrummen resten av dagarna. De andra professionspraktikernas arbete var förlagt rumsligt nära patienter och/eller de hade direkta arbetsuppgifter med patienterna. För underläkarna innebar dessa förhållanden och att de inte rutinmässigt gick in till patienterna på deras rum, barriärer som begränsade deras möjligheter att samtala med, undersöka och bedöma enskilda patienter.

4. Underläkarnas praktik innebar att de roterade varje eller varannan vecka mellan olika avdelningar och på daglig basis mellan klinikens läkargrupp och aktuell vårdavdelning eller jourverksamhet. Därigenom fick underläkarna varierande erfarenheter och förankring $\mathrm{i}$ den medicinska praktiken, men konsekvensen blev ständigt avbrutna samarbeten med vårdgivare och patienter vid de avdelningar de roterande mellan. Utformningen av underläkarpraktiken försatte enskilda underläkare ständigt i positioner av novisskap i olika sammanhangs rutiner och relationella samspelsmönster. Det till skillnad från deltagare i övriga professionspraktiker som var stationärt knutna till avdelningarna. Underläkarna hade ömsesidigt utbyte av organisatoriskt respektive medicinskt kunnande med sjuksköterskor i de tre vårdteamen och med vårdadministratör. Men sjuksköterskorna hade, till skillnad från underläkarna, möjlighet att uppdatera sig på patienter inför morgonronderna. Detta formade överlappande ekologiska kopplingar mellan sjuksköterskepraktiken och underläkarpraktiken, som begränsade underläkarnas möjligheter att ta ansvar i den medicinska processen och därigenom lära och vara aktiva i interaktionen med patienterna under rondandet.

5. Underläkarnas lärande och lärandemål var inte inkluderade i designen och implementeringen av den nya rondmodellen. I rondmodellen som fortfarande var under utveckling engagerade sig deltagarna i de stationära professionspraktikerna i sitt ömsesidiga nätverkande. Underläkarna som roterade mellan olika avdelningar riskerade i sammankopplingarna av dessa sociala aktiviteter att bli förskjutna till periferin av det framväxande samskapande rondandet. 
Vårdavdelningens ledningsteam, som ledde utveckling av rondmodellen, menade att underläkarnas lärande inte var deras ansvar. De menade att ansvaret låg på underläkarna själva och på klinikens studierektor. Detta förhållningssätt förstärkte underläkarnas position som roterande gästarbetare, med uppdrag att prestera det som varje dags rondarbete krävde. 


\section{DISKUSSION}

\section{Diskussion av avhandlingens fynd}

Avhandlingens övergripande syfte har varit att fördjupa kunskapen om och förståelsen för lärande och pedagogiska processer i hälso- och sjukvårdspraktiker, med särskilt fokus på läkare och lärande. Genom att studera ett flertal studieobjekt har både bredd och djup kunnat uppnås. Först genom studie av pedagogiska processer i relation till patienter och närstående, följt av studier av läkares lärande och stöd till andras lärande i dagligt arbete. Därefter studerades en specifik hälso- och sjukvårdspraktik och hur materiella och sociala förhållanden påverkade samspelet mellan deltagarna. I samma hälso- och sjukvårdspraktik studerades avslutningsvis underläkares lärande i det arbete de var engagerade i. Djupgående förståelse har utvecklats genom att betrakta studieobjekten genom olika kulturella och sociomateriella praktikteoretiska perspektiv.

För att markera reella utmaningar avseende lärande i dagligt arbete i dagens hälso- och sjukvård, lyfts det inledningsvis i diskussionen. Därefter diskuteras lärande i mötet mellan patienter, deras närstående och vårdgivare, följt av ett avsnitt om mångdimensionellt lärande i specifika hälso- och sjukvårdspraktiker. Med läkarna i förgrunden följer därefter två avsnitt, först diskuteras dynamik i lärandet inom och mellan vårdens olika praktiker. Därefter diskuteras de lärandepraktiker som formar underläkares lärande i deras dagliga arbete. Avslutningsvis knyts avhandlingens övergripande syfte, att fördjupa kunskapen om lärande och pedagogiska processer, till förändringar och hälso- och sjukvårdens utveckling.

\section{Begränsningar och brister för konstruktivt lärande}

Den första begränsningen att belysa i delarbete I är att den pedagogiska diskursen framstod som tyst (Polanyi, 2009). Det framkom i vårdgivarnas sätt att tala om vad de gjorde i sitt dagliga arbete, både vad de sa och inte sa. Pedagogiska processer i patientrelaterade arbetet var inbäddade i medicinskt, omvårdande och rehabiliterande arbete. Vårdgivare verkade inte systematiskt fokusera, reflektera över eller gemensamt kategorisera 
den pedagogiska delen av patientarbetet. Det hängde på vad enskilda vårdgivare själva åstadkom. Deras kunnande riskerade att förbli tyst. Stöd att professionellt utveckla pedagogiska förmågor verkade inte finnas. Inte sällan missade vårdgivarna möjligheter för att stödja patienters lärande, vilket kan förklaras av att det varken fanns träning eller tydliga diskurser för arbetets pedagogiska dimensioner i deras vårdsammanhang. Fynden i delarbete I indikerade att vårdgivare behövde fokusera på den pedagogiska delen av sitt kliniska arbete. Det överensstämmer med studier som visar att vårdgivare behöver uppmärksamma sina förmågor, föreställningar och värderingar för att kunna utveckla pedagogiskt arbete med patienter (Mikkonen \& Hynynen, 2012; Pétré, Gagnayre, De Andrade, Ziegler, \& Guillaume, 2017).

När läkare inom ett flertal discipliner beskrev sitt dagliga arbete framträdde uttalade skillnader mellan disciplinerna i hur de själva lärde och bidrog till andras lärande (delarbete II). Sachdeva har visat på skillnader mellan slutenvård och primärvård i hur läkares kontinuerliga professionella utveckling utförs (Sachdeva, 2016). Läkares uppfattningar om lärande och handledning av läkarstudenter hade variationer av betydelse för studenters delaktighet och lärande i dagligt arbete (Strand et al., 2014). Detta avhandlingsarbete fokuserar på hur läkare lär och lärstödjer när det kliniska arbetet pågår. Därmed inkluderas ständigt pågående professionell utveckling och handledning av studenter såväl som underläkare, även om det inte har specifikt studerats. Jag har inte kunnat återfinna andra studier som betraktar förutsättningarna för lärande vid läkares samspel mellan generationer av läkare, med vårdgivare i andra professioner och med patienter i dagligt arbete. Jag menar att de skillnaderna mellan olika discipliner som indikerats $\mathrm{i}$ delarbetet har betydelse inte enbart för enskilda patienter och vårdgivare, utan också för vårdens genomförande och utveckling. Det är angeläget att i fortsatta studier synliggöra och jämföra styrkor och svagheter i förutsättningar för konstruktivt lärande och lärstödjande i olika discipliner för att optimera lärande och stärka hälso- och sjukvårdens utveckling.

Rondmodellen som var sammanhanget för delarbete III hade redesignats med målsättningen att utveckla samarbete och patienters integritet. När lärande däri studerades framträdde samskapande lärande ronder med både lärande i praktiken och varierande individuellt lärande. Men allt rondande i modellen utvecklades inte på det sättet, utan förhållanden 
fördes över från det tidigare rondandet vid patienternas sängar. Det överförda rondandet präglades av mer hierarkiskt och konkurrerande agerande och passivare patienter, ett operativt rondande. Trots att vårdgivarna deltog $\mathrm{i}$ och uppskattade samskapande lärande rondande förändrades inte allt deras rondande. Att genomföra förändringarna var för dem komplext, svårt och skapade frustration.

När utförande av kvalitets- och förbättringsarbete har granskats bekräftas att svårigheter att genomföra förändringar är vanligt förekommande och pekar på betydelsen av sociala förhållanden (DixonWoods, McNicol, \& Martin, 2012; Kirkegaard \& Andersen 2018). I avhandlingsarbetet har den teoretiska modellen praktikarkitekturer hjälpt mig att i rondandet spåra flerdimensionella extraindividuella arrangemang som påverkade förutsättningarna att genomföra förändringar. Hur man på vårdenheten hade för vana att tala i och om rondandet och hur man använde informationsteknologi både bidrog till och försvårade önskade förändringar. Det gjorde också mönstren för hur man agerade och skapade utrymme för varandra och rumsliga förhållanden. Kemmis och Mutton (2012) menar att för att genomgripande förändringar skall kunna genomföras $i$ en praktik (rondandet), behöver alla arrangemang i dess praktikarkitektur synliggöras. Därigenom kan alla deltagare förstå och ta ställning till vad och hur sociomateriella förändringar skall genomföras och följas upp.

"Det är inte bara personer som behöver förändras utan förhållanden $i$ vilka vi relaterar till varandra och världen - förhållanden som vi, kollektivt har skapat, och som vi, kollektivt, måste förändra" (Kemmis \& Mutton, 2012 s. 205)

Att förändra hälso- och sjukvårdspraktiker så att ändamålsenligt lärande blir integrerat i dagligt arbete är angeläget och kräver tydliga tillvägagångsätt med allas delaktighet. I den studerade hälso- och sjukvårdspraktiken hade vårdgivarna behövt beskriva utifrån praktikarkitekturens olika arrangemang hur de var och en och tillsammans såg på rondandet och ansåg att det skulle utföras. Därefter behövde man förhandla fram en gemensam målsättning och hur genomförandet av rondandet skulle följas upp.

När underläkarnas lärande fokuserades i rondmodellen (både samskapande lärande och operativt rondande) med dess för- och efterarbete, framträdde hur vårdavdelningens underläkarpraktik i interaktion med övriga professionspraktiker begränsades och riskerade att till och med marginalisera underläkarnas lärande (delarbete IV). 
Underläkarnas lärande var inkapslat i vårdavdelningens underläkarpraktik. I interaktionen mellan professionspraktikerna synliggjordes vilka förutsättningar rondarbete erbjöd underläkarna för lärande i medicinskt praktiskt arbete. Underläkarnas lärande på vårdavdelningen gav dem inte kontinuitet, koherens och progression i att utveckla bredden av medicinskt och generellt professionellt kunnande, som de som specialister i framtiden ska behärska och Socialstyrelsens målbeskrivningar ställer krav på (SOSFS 2015:8). Motsvarande förhållanden beskrivs i ett flertal studier från vilka jag belyser amerikanska underläkares och läkarstudenters perspektiv på sin kliniska lärandemiljö (Kulaylat et al., 2017). Anmärkningsvärt i studien var att runt 80 procent av underläkarna såg sig som negligerade och hälften att deras arbetsuppgifter inte gav utbildningsvärde och att de undanhölls från/nekandes lär möjligheter i det dagliga arbetet. Dyrbye och Shanafelt (2016) har i en multicenterstudie visat att under perioden 1990-2015 frekvensen av utbrändhet bland läkarstudenter och underläkare har varit hög, högre än i andra grupper. Författarna betonade att utbrändhet försvårar gruppernas professionella utveckling, innebär risker för patienter och medför ett antal personliga konsekvenser. Den kritiska faktorn förlägger de till lärandemiljön i hälso- och sjukvården. De beskrivna förhållandena för underläkare och studenter ur ett internationellt perspektiv är ett observandum också i svensk hälso- och sjukvård.

I avhandlingens fjärde delarbete synliggjordes spänningen mellan de sätt som underläkarna var delaktiga och lärde sig i en specifik praktik (rondpraktiken) och hur deras kunnande riskerade att bli både felinriktat och utdraget över tid. Trots aktivt förbättringsarbete kunde rondpraktikerna betraktas som dysfunktionella utifrån hälso- och sjukvårdens uttalade behov av effektiv och målstyrd kompetensutveckling för underläkare. För att enskilda underläkares lärande i dagligt arbete ska vara konstruktivt behöver underläkarnas lärandepraktiker synliggöras, erkännas och utvecklas i varje hälso- och sjukvårdspraktik där underläkare deltar.

I enskilda vårdgivares samspel med patienter och närstående, i kollektivt samspel inom olika discipliner och när initiativ tas för att förbättra hälsooch sjukvårdspraktiker med underläkares lärandepraktiker som formas i dem, spelar medvetenhet om och strategier för pedagogiskt agerande en central roll. De begränsningar och brister för konstruktivt lärande i hälsooch sjukvården dagliga arbetet som avhandlingens delarbeten synliggjort, menar jag är tydliga markörer för att dessa pedagogiska dimensioner 
behöver utvecklas för att upprätthålla och utveckla hälso- och sjukvården. Genom att vårdgivare kompetent utför pedagogiskt arbete integrerat i dagligt arbete i samspel med patienter, studenter och andra vårdgivare i egna och andra professioner kan det skapa värde på ett flertal sätt.

Pedagogiskt kompetenta vårdgivare kan påverka kvalitet och effektivitet i patienternas vård, då förutsättningar för patienters perspektiv och kunnande bättre beaktas. Studenter i alla vårdrelaterade professioner liksom AT- och ST-läkare kan stärka sitt lärande och lärstödjande agerande genom att de initierat involveras i de hälso- och sjukvårdpraktiker där de deltar. Det bidrar till att snabbare få medarbetare som reellt bidrar till vårdens genomförande och effektiviserar hälso- och sjukvårdens kompetensförsörjning. Genom att synliggöra det pedagogiska värdet i arbetet vid enskilda hälso- och vårdsenheter, kan respekt och lärande mellan professioner utveckla både den vård de genomför tillsammans och deras förmåga att använda varandra i ömsesidigt beroende.

I de följande fyra avsnitten kommer jag att diskutera vad kunskaperna från avhandlingen studier kan bidra med för att stärka lärande, förmågor att stödja lärande samt att utveckla samskapande lärandepraktiker.

\section{Patienter, närstående och lärande}

Patienters hälsa och vård är kärnuppdraget i varje hälso- och sjukvårdspraktik. Denna avhandling har visat på betydelsen av hur vårdgivare i pedagogiska processer samspelar med patienter och deras närstående. Richards et al. menar att i den mångfasetterade utvecklingen som pågår med ökad patient-delaktighet, kommer kunskap, kunnande och lärande att få en alltmer central roll i möten mellan patienter och vårdgivare (Richards, Montori, Godlee, Lapsley, \& Paul, 2013). Pedagogiska processer i mötet mellan vårdgivare, patienter och också deras närstående var inbäddade i medicinska, omvårdande och rehabiliterande arbetsuppgifter och har i delarbete I beskrivits med konceptet avläsa (behov av lärande)-färdrikta-lärstödja.

För att vårdgivare kompetent skall kunna agera i pedagogiska processer och utveckla pedagogiska färdigheter behöver de resonera om och reflektera över sitt och andras pedagogiska agerande i olika patientmöten. De behöver få möjlighet att reflektera i och om sitt handlande (Schön, 1987, 2017). På motsvarande sätt som vårdgivare gör i medicinskt, omvårdande och rehabiliterande arbete, behöver de gemensamt granska och resonera om arbetets pedagogiska dimensioner 
för att kollektivt forma pedagogiska praktikgemenskaper. Att vårdgivarna som deltog i studie A föreföll sakna språk för pedagogiskt arbete, den tysta diskursen, begränsade deras möjligheter att utveckla pedagogiska färdigheter.

Genom att utveckla ett gemensamt språk för och kunnande om det pedagogiska innehållet i sitt dagliga arbete, skulle vårdgivare bättre förstå och kunna stödja patienter i deras sätt att hantera och förstå sin situation. I en sådan praktik skulle vårdgivarnas förståelse för patienternas perspektiv också fördjupas. Att intervjuade vårdgivare missade möjliga lärsituationer både för patienter och för sin egen del, tolkades som att de inte hade träning i att resonera om lärande och pedagogiska perspektiv på sitt arbete. Både fynd och slutsatser bekräftas av Mertens et.al. (2018) som visat att vårdgivare $\mathrm{i}$ flera professioner var omedvetna om det lärande som skedde genom att samarbeta. De menade att vårdgivare behöver avsatt tid för reflektion för att lära nya sätt att interagera och utveckla sitt kliniska arbete (Mertens et al., 2018).

Behovet av att synliggöra och utveckla pedagogiska färdigheter motiverades också av att vårdgivarna ofta utgick från sitt expertkunnande i delarbetets identifierade pedagogiska processer. De gjorde egna antaganden om patienters behov och involverade inte patienterna med deras perspektiv, utan förmedlade kunskap på det sätt de fann relevant. Pétré et. al. (2017) har beskrivit vårdgivares behov av att utveckla pedagogiska förhållningssätt $\mathrm{i}$ mötet med patienter med kroniska sjukdomar, för att tillsammans med dem tillgodose både vårdrelaterade och sociala behov.

Vårdgivares förmåga att resonera om och tillämpa pedagogiska processer och förhållningssätt i mötet med patienter är av betydelse för att utveckla såväl personcentrerad vård (Ekman et al., 2011) som samskapande hälso- och sjukvård (M. Batalden et al., 2016). Bland vårdgivarna i avhandlingens första delarbete framkom osäkerhet om hur de skulle agera för att patienterna skulle vara mer aktiva och delaktiga i sin vård. Att genomföra ofta spontant och oplanerat pedagogiskt arbete med avsikten att åstadkomma förändringar är svårt och utmanande. Lagstiftning och olika initiativ för att utveckla hälso- och sjukvården markerar vikten av patienters delaktighet, involvering och samskapande med vårdgivare. Det ställer stora krav på vårdgivarnas pedagogiska färdigheter. Att utveckla en verkligt samskapande hälso- och sjukvård, menar Dunston et. al., utmanar den traditionella expert-baserade hälsooch sjukvården (Dunston, Lee, Boud, Brodie, \& Chiarella, 2009).

Utveckling av samskapande hälso- och sjukvård underlättas av att informationsteknologin har möjliggjort att patienter och närstående idag uppdaterar sig om sjukdomar och behandlingsmetoder. De har tillgång 
till personliga elektroniska journaler, vilket ger dem möjligheter att bättre förstå, komma ihåg och vara involverade i sin vård (Wass, Vimarlund, \& Ros, 2017). Samtidigt som det gynnar utveckling av samskapande hälsooch sjukvård ökar med all sannolikhet bredden i patienters och närståendes förförståelse och fokus för omständigheterna i sin vård. Vårdgivares kompetens att möta denna utveckling menar jag i väsentliga delar bygger på deras pedagogiska kunnande och samspel med patienter i pedagogiska processer.

Pétré et al. (2017) beskrev att specifika utbildningsprogram om pedagogiska förhållningssätt hade gett deltagare medvetenhet och kunskaper att genomföra och prioritera pedagogiskt arbete med patienter. De beskrev det som ett vetenskapligt förhållningssätt som kompletterar biomedicinsk kunskap. Deltagarna hade därigenom med traditionell utbildning utvecklat en form av pedagogiskt expertkunnande. Fynden i avhandlingens andra studie (B) indikerar att vårdgivare också kan lära och förändra pedagogiskt kunnande i dagligt arbete. I rondmodellen agerade vårdgivare så att de balanserat och individualiserat underlättade olika patienters aktiva deltagande. Det innebar förändringar jämfört med tidigare ronder vid patienternas sängar.

Förändrade pedagogiska förhållningssätt i den studerade rondmodellen byggde inte på formell utbildning, utan på att vårdenheten hade förändrat rondandets praktikarkitekturer genom ett förbättringsarbete. En samskapande lärande rond formades i dagligt återkommande rondande. Vårdgivarnas upprepade erfarenheter av värdet med patienters involvering och deras bidrag med för vårdgivarna annars okända perspektiv, stimulerande dem att agera i pedagogiska processer för att balansera patienters aktiva deltagande. När samskapande lärande ronder över tid formades hade vårdgivare förutsättningar att simultant bidra till patienters delaktighet och lärande, själva lära av och om patienter såväl som hur de skulle förhålla sig pedagogiskt i samspelet. Deras pedagogiska kunnande och förhållningssätt framträdde i rondandet. Medvetenheten om att det de gjorde innebar ett pedagogiskt arbete, synliggjordes vid mötesplatser och reflekterande i den interaktiva forskningsprocessen, dvs. rum för reflekterande om pedagogiskt handlade i konkret arbete.

I en översiktsartikel om samskapande hälso- och sjukvård dras slutsatsen att för att samskapande ska kunna realiseras behöver kulturella och kognitiva gap mellan vårdgivare och vårdtagare överbryggas, vilket kräver 
uttalade ansträngningar både professionellt och organisatoriskt (Rocco, 2016). Bland identifierade åtgärder nämndes inte vårdgivares pedagogiska kunnande $\mathrm{i}$ arbetet med patienter, men man efterfrågade analyser på mikronivåer $\mathrm{i}$ mötet mellan vårdgivare och vårdtagare. Avhandlingen utgör ett sådant bidrag genom att visa på betydelsen av att $\mathrm{i}$ enskilda hälso- och sjukvårdspraktiker synliggöra vikten av att vårdgivare utvecklar ett gemensamt språk för och resonerar om den pedagogiska dimensionen i patientarbetet. Betydelsen av hur utformningen av hälsooch sjukvårdspraktikers praktikarkitekturer kan underlätta både samskapande och lärande, vilket diskuteras ytterligare i nästa avsnitt.

\section{Mångdimensionellt lärande i specifika hälso- och sjukvårdspraktiker}

I det tredje delarbetet studerades en specifik hälso- och sjukvårdspraktik, rondandet $\mathrm{i}$ en relativt nyligen införd rondmodell. Fokus i delarbete III var hur både materiella och sociala förhållanden påverkade samspelet mellan deltagarna i rondandet. Fynden visade att i rondandet fanns sociomateriella samspelsmönster mellan patienter och vårdgivare samt redskap såsom informationsteknologin och rumsliga arrangemang som prefigurerade och formade mångdimensionellt lärande. Det sociomateriella samspelet genererade rondande med varje patient som tillvaratog deltagarnas olika erfarenheter och kunnande, så att bedömningar och beslut hade förutsättningar att på bästa sätt gynna patienternas vård. Rondpraktikerna lärde och kom initierat vidare i de uppdrag olika professionsgrupper hade för och med varje patient.

Lärandet i rondandet möjliggjordes genom samspel mellan deltagare och extra-individuella och organisatoriska förhållanden, i spänningsfältet mellan samskapande där patienterna var medskapare och rondernas praktikarkitekturer. Dessa fynd överensstämmer med en studie av Hopwood, Fowler, Lee, Rossiter, \& Bigsby (2013), där de betonar vikten av att inte separera sammanhanget och dess deltagare för att utveckla hälso- och sjukvårdarbete.

Gherardi (2014) menar att lärande är en kollektivt skapad prestation som framträder "genomfört" socialt och materiellt, "kunnande-ipraktiken”. Det ska ställas mot att materiella förhållanden oftast tas för givna och utifrån lärandeperspektiv blir ännu mer osynliggjorda, då kognitiva och delvis deltagande synsätt på lärande dominerar (Hopwood, 2014). I delarbetet var samspelet mellan vårdgivare, patienter och informationsteknologin av betydelse för utförandet och kunnande i rondandet. Med enbart kognitivt synsätt på lärande, förlagt till vad som 
händer i enskilda individers huvuden, är det risk för att möjligheter för lärande förbises och utveckling i hälso- och sjukvårdspraktiker uteblir.

I rondandet fördjupade vårdgivarna förståelsen och förfinande ageranden, när de länkade samman varje patients unika perspektiv och behov med budskapen på datorskärmarna, med sitt medicinska eller omvårdnadsmässiga kunnande (delarbete III). I rondandet framträdde ett mångdimensionellt lärande, också för patienter. När vårdgivare i olika professioner bidrar med olika kunskaper och erfarenheter och samtidigt registrerar och respekterar varandras olika kunskaper och roller och involverar patienter efter deras förutsättningar, stärks samskapandet i rondandet/praktiken. Deltagare lär och bidrar till andras lärande sammanlänkat i samskapande lärande i ronderna, vilket överensstämmer med Kemmis teori för lärande i praktiker (Kemmis et al., 2013).

För att förverkliga förväntade förändringar och möta utmaningar i hälsooch sjukvården behövs fysiska mötesplatser i det dagliga arbetet som möjliggör samarbete och involverar patienter. Andra studier demonstrerar också att ronder har en sådan central funktion i slutenvården (Subramony, Hametz, \& Balmer, 2014; Swenne \& Skytt, 2014). Denna avhandling bidrar med att synliggöra hur samskapande och lärande i rondandet är sammanlänkat och hur arrangemang i dess praktikarkitektur både kan underlätta och försvåra. Fynden relaterar till de tre perspektiv på vårdens utveckling som Batalden och Davidoff (2007): beskrivit bättre professionell utveckling, bättre system och processer och bättre hälsa för patienter, som beroende av varandra för hållbar kvalitet och utveckling av hälso- och sjukvården. I hälso- och sjukvårdens slutenvård genomförs ronder dagligen och de tre perspektiven har potential att samtidigt och regelbundet realiseras i ett samskapande med dem hälso- och sjukvården är till för, patienterna.

Dorman och Miller har efterlyst modeller som möjliggör kunskapsutveckling integrerat i dagligt hälso- och sjukvårdsarbete (Dorman \& Miller, 2011). Jag menar att den samskapande lärande ronden helt förverkligad skulle kunna utgöra en sådan modell. I sådant rondande kan vårdgivare och patienter tillsammans utveckla mönster för hur och varför vården ska utföras med varje unik patient. Vad som ska genomföras som vårdgivarna brukar, vad som skall genomföras annorlunda, vilka risker som finns med olika ageranden och vad som behöver följas upp. I sådant rondande integreras patienternas erfarenheter och sociala förhållanden med medicinska, omvårdande och rehabiliterande kunskaper och åtgärder. Det mångfasetterade lärande 
som framträder skapar kunskapsutveckling integrerat i hälso- och sjukvårdsarbetet.

Slutsatsen från delarbete III är att i hälso- och sjukvårdspraktiker där samskapande mellan patienter, grupper av vårdgivare och materiella förhållanden utförs, framträder mångdimensionellt lärande som leder till förändringar. Simultant med att praktiken lär och utvecklar vårdens värde och kvalitet för patienter, lär såväl patienter som vårdgivare och bidrar på olika sätt till andra lärande.

\section{Läkare och dynamiken i lärande i och mellan olika praktiker}

Läkare, såväl AT-läkare, ST-läkare som mer eller mindre erfarna specialister utgör en av vårdprofessionerna som lär och influerar andras lärande i dagligt arbete. Inom den medicinska professionen finns traditioner och kulturella förhållanden med djupa historiska rötter för hur generationer av läkare lär och stödjer varandras och andras lärande i kliniskt arbete. Med olika linser i Kemmis teoretiska ramverk praktikarkitekturer har en dynamisk väv av lärande i läkares samspel med andra vårdgivare och patienter på olika sätt kunnat spåras i delarbete II, III och IV. Centralt för läkares lärande och lärstödjande var deras aktiva deltagande och interagerande i individuella patienters processer genom vården. Det kan förefalla självklart, men både avhandlingens fynd och andra studier visar att konkurrerande, framförallt administrativa arbetsuppgifter, tränger undan arbete med patienter (Sinsky et al., 2016).

Läkares eget lärande och lärstödjande agerande framträdde genom hur de förstod, agerade och relaterade i samspel med övriga deltagare i de olika praktiker de deltog i. Praktikarkitekturernas sociomateriella arrangemang varierade mellan de olika praktiker enskilda läkare alternerat arbetade i. Variationerna föreföll vara ännu större mellan olika discipliners praktiker, vilket talar för att läkare i olika discipliner har olika förutsättningar för lärande och lärstödjande arbetande i dagligt arbete.

När de olika hälso- och sjukvårdspraktiker, som enskilda patienters vårdprocesser flödar igenom, är så arrangerade att läkare tillsammans med andra vårdgivare gemensamt utifrån bredden av kunskap de representerar kan utforska problemställningar uppstår mångdimensionellt lärande. Därigenom kan en specifik hälso- och sjukvårdspraktik konstruktivt fullfölja, upprätthålla och utveckla sitt uppdrag och vara ett rum för lärande både för praktiken och enskilda deltagare. 
Då däremot hälso- och sjukvårdspraktiker där läkare interagerar med flera professioner har traditionen att enbart fokusera medicinska dimensioner i patientuppdraget, domineras det gemensamma arbetet av läkarnas kunnande utan att vävas samman med andra professioners kunnande. Därmed bidrar läkare med eller utan intentioner till de andra professionernas lärande. Medan läkarna själva inte lär och utvecklar förståelse för vad kunnande i andra vårdprofessioner betyder för genomförandet av vården. Hur samspel mellan läkare och andra vårdprofessioner utförs, påverkar deras förståelse och kunnande om hur de bidrar och kompletterar varandra i helheten av den vård de utför. Om vårdgivare har begränsade kunskaper om hur olika professioner bidrar till vården, riskerar patienterna att inte få den vård som skulle kunna vara möjlig. Dessutom kan möjligheter att förändra vården försvåras. När läkare med sina kunskaper och erfarenheter aktivt bidrar till andras kunnande, förfinas deras eget kunnande. Det sätt som läkare stödjer andras lärande påverkar vilket kunnande både de andra och läkaren själv utvecklar.

Delarbete II synliggjorde hur läkares lärande och stödjande av andras lärande alternerade dynamiskt i deras dagliga arbete. Att synliggöra och tillsammans med andra reflektera över de pedagogiska dimensionerna i dagligt arbete, kan konstruktivt bidra både till vårdens utförande och till enskilda personers lärande.

När jag reflekterar över vad fynden i mina studier säger i relation till tidigare forskning inom området så framstår i samspelen mellan läkare och andra deltagare i hälso-och sjukvårdspraktiker ett antal övergripande teman som har betydelse för att stimulera och stödja lärande. Gemensamt i dessa teman är att lärande stimuleras genom att det som uppstår tycks skapa friktion i praktikerna eller för enskilda deltagare. Med friktion menar jag störning av invanda mönster, ifrågasättanden eller krav på ansträngning för att komma vidare i arbetet. Friktionen kan bli allt för kraftfull, med utmaningar som "river", skapar obehag, genererar undvikande, motstånd eller flykt, med begränsat eller icke konstruktivt lärande som följd. Praktiker som har lite friktion menar jag kan upplevas som bekväma och vara kompetenta i det de gör för stunden. Men mitt antagande är att lärande då är begränsat och förändringar svårare att åstadkomma. 
Teman som identifierats i studierna och som med balanserad friktion stimulerar och stödjer lärande:

1 nya, tillfälliga eller novisa deltagare

2 problem som inte har självklara lösningar

3 osäkerhet och oväntade situationer

4 relationella spänningar när olika perspektiv möts

5 relationella spänningar i ansvarstagande

6 läkares mobilitet

1 När i hälso- och sjukvårdspraktiker nya, tillfälliga eller novisa deltagare hade legitimitet att uttrycka behov och bidra med sina perspektiv skapade det vitalitet och stimulerade lärande och lärstödjande agerande (II, III, IV). I studierna handlade det om patienter, närstående, roterande underläkare och vårdgivare från andra vårdenheter eller discipliner med konsultativa uppdrag. Jag menar att också studenter i olika professioner och nyanställda inklusive de med utbildning $\mathrm{i}$ andra länder kan inkluderas. Dessa grupper har gemensamt att de inte är familjära med den aktuella praktikens traditioner, rutiner och sätt att samarbeta. Vanligen är de motiverade att förstå och interagera i den praktik de deltar i. Dessutom kan de ha kunskaper, erfarenheter eller behov som kan vara av värde i praktiken. Bidrar praktikens praktikarkitektur till att dess vårdgivare med pedagogiskt kunnande kan samspela med nya, novisa eller tillfälliga deltagare underlättas dessa gruppers deltagande och lärande. Därigenom kan praktiken ruckas eller stimuleras så att ömsesidigt lärande sker.

Handledning och klinisk utbildning är ingående studerat internationellt och en svensk studie fokuserar på läkarstudenters lärande i relation till enskilda handledares sätt att handleda (Strand et al., 2015). Det jag tydliggör här är hur hälso- och sjukvårdspraktiker utvecklar meningsbärande ageranden, etiska värdegrunder och regler som underlättar flera gruppers likartade situationer. Kilminster, Zukas, Quinton och Roberts (2010) argumenterar för att det finns en kritisk, intensiv lärandeperiod (CILP), för underläkare när de roterar från en vårdenhet och kommer nya till en annan. De menar att vårdenheterna och de som arbetar där uttalat influerar underläkarna och har ansvar för att vården är så arrangerad att den underlättar deras deltagande och lärande. Jag menar att kritiska, intensiva lärperioder är relevanta för fler nya, novisa och tillfälliga deltagare som tillhör olika professioner. Hälso- och 
sjukvårdens verksamheter behöver tydliggöra den pedagogiska dimensionen av sitt uppdrag och utveckla hur de samspelar med nya, novisa och tillfälliga deltagare.

2. När i hälso- och sjukvårdspraktiker problem uppkom som inte hade självklara lösningar eller när det fanns flera alternativa lösningar och praktikerna underlättade att deltagare gemensamt bearbetade hur man skulle gå vidare stimulerades lärande (II, III). Det är i samklang med Greenhalgh, Howick, \& Maskrey (2014), som betonar vikten av meningsfulla samtal i sammanhang med humanistiska och professionella vårdgivar-vårdtagarrelationer. De beskriver hur situerad individualiserad evidens därigenom utvecklas för att kunna fatta välgrundade beslut. Avhandlingens fynd synliggör att i gemensam problembearbetning framträder lärande som sannolikt positivt influerar beslutsfattande.

3. När i hälso- och sjukvårdspraktiker osäkerhet och oväntade situationer uppstod, kunde det stimulera lärande (II, II, IV). När vårdgivare resonerar om den osäkerhet som uppstår i hälso- och sjukvårdsarbete, menar Engebretsen, Heggen, Wieringa och Greenhalgh (2016) att det blir en produktiv komponent för lärande. De innefattar i resonerande reflektiva frågor, kreativitet, öppenhet för det oväntade och kritiska bedömningar i specifika här och nu situationer, som ger förutsättningar för att utveckla objektiv kunskap. Ett sådant förhållningssätt ställer de i kontrast mot att strikt följa evidensbaserade riktlinjers standardiserade rekommendationer.

Osäkerhet och oväntade situationer är vanligt förekommande i hälsooch sjukvården och återkom upprepat i studierna. Som exempel lyfts underläkargruppen med osäkerhet i praktiska moment (II) och i rondarbete (IV), som genererade praktisk handledning och kliniska resonemang med mer erfarna läkare. När mindre erfarna underläkares osäkerhet betraktas som produktiva komponenter i dagligt arbete, bör det motivera till lärande samspel. Det kan och bör förbättra underläkares förutsättningar för att lära reflektivt och utveckla praktisk klokskap, så väl som handledande läkares lärstödjande kompetens.

4. När i hälso- och sjukvårdspraktiker det uppstod relationella spänningar genom att olika perspektiv exponerades, stimulerades lärande. Det skedde när vårdgivare från flera professioner eller discipliner tillsammans bearbetade problemställningar i praktiker (II, III, IV). Interaktion mellan professioner ger förutsättningar för perspektivbyten som stimulerar lärande, men många är erfarenheterna av att välutvecklad interaktion 
mellan vårdens professioner är svårt att utveckla. Crocker et al. betonade vikten av vårdsammanhang som präglas av respekt, ömsesidighet och synliggörande av interprofessionella relationer för att hälso- och sjukvårdens professioner och studenter ska utveckla interprofessionellt samarbete och lärande (Croker, Brown, Little \& Crowley 2016). Vestergaard och Nörgaard (2018) visade att vårdgivares gemensamma fokus på patienters vårdprocesser, med stöd av instruktörer kunniga i interprofessionellt samarbete gynnade utveckling av interprofessionellt samarbete. Men de konstaterade att det fanns kulturella och organisatoriska barriärer. I sammanhanget för den samskapande lärande ronden bidrog rondens förändrade praktikarkitektur, som medförde organisatoriska och begynnande kulturella förändringar, till interprofessionellt samskapande (III). Ronden utgjorde en avgränsad praktik där fokus var utförandet av patienters vård i samarbete med patienter. Men när samspel övergick i operativ rondande var utbyten mellan olika perspektiv begränsade eller obefintliga och friktion som stimulerade lärande låg. Att avgränsat i en enskild hälso- och sjukvårdspraktik förändra relationella förhållanden i gemensamma patientrelaterade arbetsuppgifter och däri betrakta spänningar vid perspektivbyten som produktiva komponenter, bör höja förutsättningar för lärande och utveckling av interprofessionellt samarbete.

5. När i hälso- och sjukvårdspraktiker det uppstod relationella spänningar i professionellt ansvarstagande stimulerades lärande. I delarbete II synliggjordes spänningar mellan att ge och ta på sig ansvar, att fatta beslut självständigt eller med stöd, och i engagemang för uppdaterande och utveckling av medicinska riktlinjer och arbetssätt, respektive att ta del av och tillämpa dess resultat. Liksom i övriga teman illustrerar det kopplingen mellan läkares lärande och stödjande av andras lärande $\mathrm{i}$ samspel med patienter, andra professioner och generationer av läkare.

Wearne et al. betonar vikten av att kontinuerligt genomförda ickehierarkiska, stödjande handledande relationer som innefattar en fysisk distans, så att ST-läkare lär sig "kliniskt kurage" genom att ta ansvar för patienter (Wearne, Dornan, Teunissen \& Skinner, 2015). I delarbete IV iscensattes ett materiellt arrangemang med sådan rumslig distans mellan överläkare och underläkare i kombination med sammanlänkning via telefon och informationsteknologi, vilket stimulerade underläkarnas ansvarstagande. För att friktionen i underläkarnas ansvarstagande ska leda till praktiker där de också lär och utvecklas, förutsätts etablerade relationer med utrymme för kliniska resonemang. Förtroendefulla relationer har betydelse både för handledares givande av ansvar, 
underläkares utveckling av självständighet i arbetet och samarbete med övriga vårdgivare.

ST-läkare behöver i sitt dagliga arbete samtidigt etablera förtroende och ge ansvar till AT-läkare, så att AT-läkares arbete blir meningsfullt och lärorikt (Sheu et al., 2016). ST-läkare är i positionen att både vara i behov av stöd från mer erfarna specialister och själva ha en handledande roll. För ST-läkare blir spänningar i ansvarstagande mångdimensionellt genom att de dagligen är i situationer av att ge, ta och utveckla eget ansvar. Min slutsats är att om friktionen för ST-läkare är balanserad stimulerar dessa förhållanden för ansvarstagande uttalat deras lärande.

Dagligt hälso- och sjukvårdsarbete behöver arrangeras så att överföring av ansvar och ansvarsfullt arbetet ger balanserad friktion för enskilda vårdgivare, så att lärande däri optimeras och vårdarbete utförs kompetent.

6. När läkare rörde sig mellan olika hälso- och sjukvårdspraktiker, mellan olika arbetsgrupper, olika arbetsuppgifter och olika fysiska och virtuella rum stimulerades lärande. Det utgjorde materiella arrangemang i form av mobilitet. I delarbete II varierade mönstren för läkares mobilitet mellan olika discipliner och mellan generationer av läkare. Mobiliteten innebar för läkarna ett varierat arbete som stimulerade till jämförelser. Dessa jämförelser utgjorde källor för deras lärande. Dessa fynd är i linje med Beckett och Hager som menar att en av de viktigaste faktorerna för kvalitet i arbetsplatsbaserat lärande är variation i det arbete man deltar i (Beckett \& Hager, 2000). Jag menar att det lärande som läkares mobilitet genererar också kan vara lärstödjande för dem de samspelar med i de olika praktiker de deltar i.

Läkarnas mobilitet mellan olika grupper innebar att deras förflyttningar involverade dem i olika professionella praktiker med olika uppdrag, sociomateriella arrangemang, medlemmar inom andra professioner och läkare i egen och andra discipliner (II). Det medförde att mobiliteten genomsyrades av identifikations- och socialisationsprocesser av betydelse för lärandet. I relation till enskilda patienter och patienters diagnosgrupper innebar mobiliteten att läkare kunde möta samma patient och/eller patienter från specifika diagnosgrupper i olika faser av deras process genom vården. Det medförde att läkarna som personer bar åtminstone delar av kontinuiteten i relation till patientgruppers processer genom olika hälso- och sjukvårdspraktiker. Därigenom kunde de, i relation till mer stationära vårdgivargrupper, bidra med kunnande av såväl medicinsk som organisatorisk natur. Dessa fynd överensstämmer med Fang, Lee och Schillings (2010) beskrivning av att mindre stabila 
grupper som är moderat sammanlänkade av medarbetare som rör sig mellan grupperna, ger förutsättningar för att idéer och förställningar kan flöda genom en organisation och genererar bäst långsiktigt lärande och utveckling

Läkarnas virtuella mobilitet möjliggjorde, med stöd av olika former av informationsteknologi, att de genom texter och i samarbete med andra personer eller grupper lokalt, regionalt och internationellt kunde dela och uppdatera kunskaper.

När läkarnas mobilitet (II) kontrasteras mot den studerade specifika rondpraktiken (IV) framträder tydliga skillnader i mobiliteten för specialistläkare och underläkare. De mer erfarna specialistläkarna var mer varaktigt knutna till de sammanhang som omfattades av deras mobilitet jämfört med underläkarna. Underläkarnas frekventa roterande mellan olika avdelningar och kliniker innebar istället ständiga avbrott i samarbete, för uppdrag i nya sammanhang med nya samarbetspartners. Spilg, Siebert och Martin (2012) menar, grundat på Lave och Wenger (1991), att underläkare utvecklar sin professionella identitet, socialiserar och förflyttar sig successivt in mot centrum av en praktikgemenskap som en vårdavdelning. Det sker genom att över tid delta i vårdavdelningens arbete och därigenom utveckla sitt kunnande. Fynden i mina studier bidrar med att synliggöra att underläkarnas roterande försvårade deras möjligheter att delta professionellt i och växa in i varje ny hälso- och sjukvårdspraktiks praktikgemenskap. De friktioner som uppstod krävde deras fokusering på lokala och för dem nya rutiner, diskurser och relationer för att en kort tid etablera sig i ett nytt sammanhang. Underläkares frekventa roterande har sin tradition i att skapa variation i arbete inom olika medicinska områden, men konkret också för att dagligen "bemanna" olika vårdsammanhang. Väl arrangerad mobilitet i hälso- och sjukvården potentierar lärande och utveckling och dåligt arrangerad mobilitet riskerar att slå sönder förutsättningar för underläkares lärande. Hur läkares mobilitet arrangeras med hänsyn till olika professionsgrupper och praktikers uppdrag och behov är avgörande för att potentiera lärande och lärandestöd.

Sammanfattningsvis synliggör avhandlingens fynd hur både materiella och sociala förhållanden sammanlänkat prefigurerar lärande hälso- och sjukvårdspraktiker, där sättet på vilket deltagare samspelar har avgörande betydelse. Boud beskriver produktiv reflektion som reflektion kontextualiserad i arbetet och som knyter samman arbete och lärande så 
att det blir kollektivt och organisatoriskt orienterat (Boud, 2010). Avhandlingens fynd indikerar att tid och rum för produktiv reflektion i flödet av professionella, interprofessionella, interdisciplinära och med patienter samskapande praktiker och med involvering av informationsteknologi och andra redskap, genererar kunnande och utveckling.

Dynamiken i lärande i och mellan praktiker innefattar både kollektivt lärande och enskilda personers olika lärande. Lärandet har i denna avhandling kontextualiserats i olika former av samspel i studerade hälsooch sjukvårdspraktiker med stöd av Kemmis och Mahons (2017) teori om utbildning, som jag sammanfattar på följande sätt: Lärande framträder (1) i uttrycksätt i praktiker och former för deltagande personers förståelse, (2) i praktikers värnande om och utveckling av arbetssätt och individers formande av sitt agerande i praktiken, (3) i ställningstaganden i praktiker för att säkra sociala sammanhang och individers sätt att relatera till varandra. Kemmis (2013) menar att i professionella praktiker lär på individnivå såväl de mindre erfarna som de erfarna deltagare, de senare lär genom att förfina och modifiera det kunnande de har. Avhandlingsarbetet synliggör att för att erfarna läkare ska lära behöver de i sitt dagliga arbete vad jag kallar friktion som i sampelet med andra stimulerar lärande.

\section{Underläkares lärandepraktik i hälso- och sjukvårdspraktiker}

Mot bakgrund av indikationer om marginalisering av underläkares lärande i hälso- och sjukvårdspraktiker som diskuterades i det första avsnittet av diskussionen, är det nu angeläget att ytterligare diskutera fynden som rör underläkares lärande i relation till annan forskning. Avhandlingen bidrar med fördjupade kunskaper om lärande och pedagogiska processer i mötet med patienter och deras närstående, om dynamiken i hur läkare lär och stödjer andras lärande och om mångdimensionellt lärande i det samspel som pågår i specifika hälso- och sjukvårdspraktiker. Allt sammanfattat utgör sammanhang där underläkare ska utvecklas till kompetenta specialistläkare och goda samspelare i komplexa hälso- och sjukvårdspraktiker.

Det är ansenliga delar av läkares reglerade utbildning, såväl före som efter legitimation, som är förlagd till och har långa traditioner av att genomföras i det dagliga hälso- och sjukvårdarbetet. Både den beskrivna hotande marginaliseringen, förändringstryck och kraven som finns på hälso- och sjukvården, gör det nödvändigt att granska och förbättra förutsättningarna för underläkares lärande i hälso- och sjukvårdens 
dagliga arbete. I svensk hälso- och sjukvård är det extra angeläget med anledning av pågående och nyligen genomförd reformering av grundutbildning samt AT- och ST-läkares utbildningstjänstgöringar.

Därför bidrar fördjupad kunskap och förståelse för hur underläkare lär när de arbetar specifika hälso- och sjukvårdspraktiker till det som bör förbättras och hur förbättringar kan genomföras. Avhandlingen bidrar med en bredd av kunskaper som är förankrade i praktikteoretiska perspektiv och därför har kunnat spåra förhållanden för underläkares lärande i komplexiteten av det som sker i kliniskt arbete.

Genom att betrakta underläkares gemensamma arbete som underläkarpraktiker, unika för varje klinisk verksamhet, fångas de uppgifter, arbetssätt upp som präglar underläkararbetet i verksamheten. Underläkarpraktiker i hälso- och sjukvårdsverksamheter menar jag är unika och relativt beständiga. Till dessa verksamheter kommer och går olika underläkare och deras arbete formas av verksamhetens underläkarpraktik.

Aktuella studier har visat att allt underläkararbete inte konstruktivt bidrar till underläkarnas lärande. Deras förutsättningar för lärande kan ytterligare synliggöras genom att i vårdverksamheternas underläkarpraktiker rama in underläkarnas lärandepraktiker. Därigenom synliggörs hur extraindividuella förhållanden i verksamheterna formar dessa lärandepraktiker som möjliggör eller begränsar för underläkares lärande. Med andra ord, vad underläkare lär hänger inte enbart på dem själva och hur de "tar för sig" i dagligt kliniskt arbete.

För att enskilda underläkares lärande i dagligt arbete skall vara konstruktivt behöver underläkares lärandepraktiker i olika verksamheter tydliggöras, erkännas och utvecklas i samspel med andra professionspraktiker i varje hälso- och sjukvårdspraktik där underläkare deltar.

När underläkares lärandepraktik i sin helhet synliggjordes i delarbete IV blev det uppenbart att den aktuella hälso- och sjukvårdspraktiken varken gav förutsättningar för att uppfylla de lärandemål som var relevanta eller för kontinuitet, koherens eller progression i underläkarnas dagliga arbete. En slutsats var att underläkarnas lärande var taget för givet, inte problematiserades och inte integrerades som en del av hälso- och sjukvårdspraktikers uppdrag. Billett (2016) har beskrivit spänningen mellan uppdragen att vårda patienter och att utbilda underläkare. Han 
menar att denna spänning förstärks av tysta lösningar (ett dolt curriculum). Stroud, Oulanova, Szecket och Ginsburg (2012) beskrev att ST-läkare flexibelt och altruistiskt avstod från att utveckla sina erfarenheter till förmån för patienter och deras vård. Fynden $i$ avhandlingen överensstämmer med dessa studier. En reservation är att det inte räcker att, eller till och med skapar felaktiga förväntningar om, underläkares lärande betraktas som något som sker genom utbildning, separat från det lärande som sker i kliniskt arbete. Ledger \& Kilminster (2010) har framfört kritik mot uppdelning av praktik och lärande i läkares kliniska arbete. Avhandlingens delarbeten visar med tydlighet hur grundläggande ett aktivt deltagande och successivt avancerande och ansvarstagande i det medicinskt praktiska arbetet är för underläkares lärande.

Kilminster (2010) har visat att underläkares frekventa roterande mellan olika avdelningar medförde att förväntningarna på deras deltagande var låga och begränsade vilket arbete de fick utföra. Samma mönster framträdde i delarbete II, där dessutom sammankopplingarna med överläkar- och sjuksköterskepraktiken och deras behov i första hand formade underläkarpraktiken. En tillspetsad tolkning är att på så sätt formades underläkarpraktiken till en resurs för att fullfölja och underlätta andra professionspraktikers uppdrag. Det behöver i sig inte innebära att arbetet inte är meningsfullt utifrån att underläkarna utvecklar sitt kunnande.

Andra professionspraktikers influerande på utformningen av underläkarpraktiken dominerades av förväntningar på underläkares administrativa patientarbete. Det utfördes till stor del som ensamarbete och sammankopplingarna med överläkarpraktiken byggde, åtminstone explicit, på underläkares avvaktande sökande efter stöd. Samtidigt som lärande uppstod $\mathrm{i}$ det tilldelade ansvaret, uteblev möjligheter till fördjupning och korrigering av underläkares förståelse och genomförande genom kliniska resonemang med mer erfarna läkare. Amerikanska studier har visat att utvecklingen och användningen av informationsteknologin är dominerande i läkares dagliga hälso- och sjukvårdsarbete (Sinsky et al., 2016). Mina fynd indikerar att samma förhållande råder i svensk hälsooch sjukvård och att det finns tecken på förskjutningar av administrativa uppgifter från överläkare till underläkare.

Enligt Hunt, Bell, Baker och Howard (2017) medförde elektroniska journaler, trots att de på många sätt är funktionella resurser, att läkares arbetstid dominerades av dem i en sådan omfattning att deras roll riskerade att "övergå från medicinska experter till administrativa byråkrater". Simultant menade de att patienterna transformerades till 
digitala entiteter med standardiserade tillstånd, behandlingar och mål. Givet en sådan utveckling är underläkarna extra utsatta. Reich argumenterar att den ökande användningen av olika teknologier såsom elektroniska journaler kan erodera läkares diagnostiska sensibilitet och begränsa deras värderingar av sociala och emotionella aspekter i patientarbetet (Reich, 2012). Det är angeläget att underläkarpraktiker i sammankopplingarna med andra professionspraktiker och tekniska hjälpmedel formas så att deras arbete balanserat omfattar det som dagens och framtidens specialistläkare behöver behärska.

Fynden i delarbete IV synliggjorde att de ekologiska sammankopplingarna mellan olika yrkesgruppers arbetssätt i mer omfattande sammanhang än den studerade vårdavdelningen innebar att underläkarna hade påtagligt lite direkt interaktion med patienter. Det måste tas som en allvarlig signal på att underläkarnas lärandepraktiker i hälso- och sjukvårdens verksamheter behöver granskas och förändras. Ska framtidens medicinskt ansvariga läkare kompetent utföra en samskapande hälso- och sjukvård i samspel med patienter och andra vårdgivare, måste hälso- och sjukvårdens praktiker utveckla sina praktikarkitekturer så att deras underläkarpraktiker ger underläkarna förutsättningar att arbeta med patienter. Konkret innebär kan det innebära att underläkarna ges förutsättningar att följa individuella patientprocesser och därigenom kan knyta både medicinska och generiska kunskaper till enskilda patienters progression i utredning, behandling och individperspektiv.

Sett i ett bredare perspektiv handlar en sådan förändring om att i delar av den medicinska professionen återerövra och omforma den humanistiska läkekonsten (Marcum, 2008), till samskapande praktiker med patienter, deras närstående och med vårdgivare i andra professioner. För underläkare innebär det att generiska kunskaper såsom kommunikation, ledarskap, teamarbete, systemförståelse och kvalitetsoch förbättringsarbete förankras teoretiskt och tillämpas reflektivt i det dagliga kliniska arbetet. Avhandlingen handlar om hur lärande sker och inte vad lärande består av, men utifrån uttalade behov av förbättringar av underläkares lärandepraktiker diskuteras begränsat också innehållet deras lärande.

Flera generiska kunskapsområden, exemplifierade ovan, relaterar till underläkares kompetens att med olika förtecken interagera med patienter, andra vårdgivare och andra samarbetspartners. För att 
underläkares lärandepraktiker ska ge dem förutsättningar att utveckla olika generiska kompetenser, behöver krav riktas mot hälso- och sjukvårdens verksamheter, deras enheter och de läkare som har handledande uppdrag. Handledande läkare har själva vanligen utvecklat den aktuella kompetensen genom sina kliniska erfarenheter. Det är därmed inte självklart att de har kompetens att stödja och bedöma underläkarnas agerande och lärande.

I andra länder brottas man med utmaningarna att forma förutsättningar för underläkarnas kunskapsutveckling inom generiska kunskapsområden och hur handledare kompetent ska skapa kliniska situationer för och bedöma underläkarnas lärande, vilket beskrivs i avhandlingens bakgrund. Utifrån svensk medicinsk utbildningstradition bör beaktas att det finns skillnader i hur läkarutbildning realiseras både före och efter legitimationen och i hur hälso- och sjukvårdsystemen är utformade jämfört med ett flertal andra länder. Att på motsvarande sätt arrangera utbildningssituationer i kliniskt arbete och genomföra externa utbildningar för ST-läkares handledare skulle sannolikt vara svårt att med bredd genomföra i svensk hälso- och sjukvård på grund av begränsade resurser och tveksam motivation. Dessutom skulle ST-läkare och deras handledare parallellt i olika rum genomgå liknande typ av utbildning och därmed upprätthålla expertperspektiv och traditionell hierarki.

Avhandlingens fynd har relevans för hur underläkares lärande av generiska mål kan förverkligas i deras dagliga kliniska arbete. I samskapande lärande hälso- och sjukvårdspraktiker skapas rum för mångdimensionellt lärande. I hälso- och sjukvårdspraktiker, såsom det studerade rondandet, tillämpas dagligen områden som ingår i ST-läkares generiska kompetenskrav, till exempel medarbetarskap, ledarskap, patientkommunikation och etiska frågeställningar. Hälso- och sjukvårdspraktiker som utförs samskapande kan ge underläkare utrymme att mångfasetterat agera i medicinska arbetsuppgifter och däri utveckla sitt kunnande. Att dessutom ge rum för att i eller i anslutning till arbetet produktivt reflektera omkring gemensamt arbete, stärker kunnandet för deltagarna i praktiken, både för underläkarna och för deras handledande kollegor. Detta exemplifierar en inriktning för att utveckla underläkares lärande i dagligt kliniskt arbete, med värde också för andra vårdgivare och praktiker i sin helhet. En sådan inriktning för att utveckla underläkares lärandepraktiker, är kongruent med en samskapande hälso- och sjukvård.

Intentionerna i svensk hälso- och sjukvård är att skapa bättre och säkrare vård genom en rad initiativ som stärker dess kompetensförsörjning, reell 
involvering av vårdtagare och evidensbasering. Underläkare, såväl som studenter i olika professioner, behöver tydligt inkluderas som betydelsefulla vårdgivare/deltagare i samskapande hälso- och sjukvårdspraktiker. Därigenom kan hälso- och sjukvårdspraktik formas både utifrån patienters vård och nämnda gruppers behov av att meningsfullt utveckla sitt kunnande.

Rondmodellen som började utveckla samskapande lärande ronder infördes genom förbättringsarbete som involverade alla vårdgivare på avdelningen, utom underläkarna som ständigt skiftade. Fynden från studien av rondandet indikerade att ordinarie vårdprofessioner fortfarande hade engagemang i att utveckla sitt gemensamma samarbete och deras involvering av patienter, medan de skiftande underläkarna förblev perifera. Det medförde ytterligare risker för marginalisering av underläkarnas lärandepraktik. I rondandet utvecklade underläkarna genom sitt iakttagande perspektiv på utförandet av ronderna som hade kunnat tas tillvara för utvecklingen av dem. Fynden från min studie kan ses som ett exempel på det som Fang beskriver som att nya teamstrukturer kan åstadkomma nya isoleringar genom att teamet fokuserar sin egen praktik och därigenom begränsar samarbete över professionella och organisatoriska gränser (Fang et al., 2010).

Avhandlingens fynd talar för att underläkare utgör en grupp bland hälsooch sjukvårdens vårdgivare som riskerar att "användas" felaktigt och utgöra en dold resurs i hälso- och sjukvården. Underläkare har en grundutbildning med omfattande verksamhets integrerat lärande och som nyutexaminerade är de i regel motiverade, nyfikna och angelägna om att utvecklas i arbetet. Förutsättningar för underläkares lärande i kliniskt arbete variera och min erfarenhet är att det finns många goda exempel. Det avhandlingen mer generellt kan bidra med är att vårdens verksamheter har lärandepraktiker som underläkare vandrar in och ut i. Det som behöver synliggöras och i många fall utvecklas är att underläkarna konstruktivt kan lära genom att avancerar i medicinskt praktiskt arbete.

\section{Lärande, förändringar och hälso- och sjukvårdspraktikers utveckling}

Avslutningsvis relaterar jag avhandlingens övergripande syfte om fördjupad kunskap och förståelse för lärande och pedagogiska processer i hälso- och sjukvården till de många utmaningar hälso- och sjukvården har och står inför. 
I hälso- och sjukvården tas många initiativ från både övergripande och lokala ledningar för att möta de många utmaningar som beskrevs i avhandlingens introduktionsavsnitt. Denna avhandling har fokuserat de mikrosystem där vårdens värde skapas med patienterna (Nelson, Batalden, \& Godfrey, 2007). Modellen kliniska mikrosystem bidrar till att förändra traditionella synsätt på komplexitet och samverkan i hälso- och sjukvårdssystem, vilket är nödvändigt för att förändring och utveckling ska ske (Likosky, 2014). Kliniska mikrosystem har beskrivits och används inom ramen för hälso- och sjukvårdens kvalitets- och förbättringsarbete. De perspektiv med vilka vården betraktas och beskrivs påverkar vad som är möjligt att åstadkomma. Greenhalgh (2014) menar att förbättringsvetenskap och informationshantering behöver länkas samman med pedagogiska teorier för att skapa sammanhållna arbetssätt. Men säger samtidigt att det sällan genomförs i praktiken.

Modellen "föredömliga vård- och lärandeenheter" kopplar i sådana enheter samman förbättringar, informationshantering och lärande i samspel mellan vårdtagare, vårdgivare, grupper med lärandemål som underläkare och studenter och dess ledare (Headrick et al., 2016). Det bidrar till att konkretisera viktiga förutsättningar för både patienternas vård, underläkarna lärande och utförandet av vården så att utveckling och lärande sker. Modellen bidrar däremot inte med teoretiskt grundade förklaringar om hur kunnande eller lärande konstruktivt utvecklas. Denna avhandling bidrar med sociomateriellt praktikteoretiskt grundande kunskaper om lärande i hälso- och sjukvårdpraktiker, som utvidgar förståelsen av hur mikrosystem fungerar och kan vara ett tillskott för att utveckla sammanhålla arbetssätt för att förbättra vårdens genomförande.

Francisco et. al. menar att praktikarkitekturer inte enbart är en teoretisk och analytisk resurs, utan också en resurs för att transformera och genomföra förändringar i konkreta sammanhang (Francisco et al., 2017b). När praktikarkitekturer används för att genomföra förändringar spåras vad som händer situerat i specifika praktiker och hur diskursivtkulturella, materiellt-ekonomiska och socialt-politiska arrangemang är sammansatta. Det ger deltagare i den specifika praktiken kunskaper om hur de kan re-designa praktiken både materiellt och socialt genom det sätt de agerar för att nå önskade förändringar. Praktikarkitekturer kan tillföra djupare förståelse om specifika kliniska mikrosystem och däri utveckla möjligheterna att integrera lärande, förändring och praktik. Ramverket praktikarkitekturer är i samklang med utvecklingen inom 
förbättringsvetenskapen där betydelsen av lärande hälso- och sjukvårdssystem i ökande grad uppmärksammats (Foley \& Vale, 2017).

Hälso- och sjukvårdens ledare kan genom synliggörande av hur lärande, förändringar och praktiker sammanfogas i samskapande lärande hälsooch sjukvårdspraktiker få ytterligare underlag för hur de strategiskt kan agera i ledningen av hälso- och sjukvårdens förändringsprocesser. Så väl medarbetare i hälso- och sjukvårdens mikrosystem, som ledare i vårdens alla system kan fördjupat förstå hur lärande sker i dagligt hälso- och sjukvårdsarbete, så att initiativ för utveckling som tas förstärker och inte försvårar lärande och konstruktiva förändringar.

\section{Diskussion om avhandlingens trovärdighet och kvalitet}

I detta avsnitt diskuteras mer generella strategier för trovärdighet och kvalitet i helheten av min forskning. Därutöver innehåller studiernas delarbeten detaljerade beskrivningar av data och procedurer om hur den använts på ett trovärdigt och kvalitativt bra sätt. Kvalitativ forskning behöver vara rigoröst genomförd med en variation av teoretiska konstruktioner, datakällor, studiesammanhang och urval, med redskap eller instrument som är minst lika komplexa, flexibla och mångfasetterade som de fenomenen som studeras (Tracy, 2010).

Intern logik i forskning innebär att forskningsfrågor, datainsamling och analystekniker, såväl som antaganden om det studerade fenomenet och hur forskningen bedrivs harmoniskt hänger samman i en helhet (Larsson, 2005). Denna avhandling förverkligar en sådan intern logik, som inkluderar att den successiva förtrogenheten med forskningsfältet och genererade fynd har medfört successivt skärpta problemformuleringar och variationer av metodologin.

\section{Trovärdighet}

Trovärdig forskning karaktäriseras av att läsare uppfattar forskningens fynd så pålitliga att de kan agera och fatta beslut utifrån dem. Kvalitativ trovärdighet kan uppnås genom fylliga beskrivningar, triangulering och deltagande reflektioner (Tracy, 2010). I delarbetena såväl som avhandlingens kappa presenteras fylliga beskrivningar av forskningen för att visa hur den i sin komplexitet har genomförts. Triangulering möjliggör trovärdiga slutsatser genom att två eller flera källor av data, teoretiska ramverk, sätt att samla in data eller flera forskares analyser löper samman 
i gemensamma slutsatser. Avhandlingen omfattar flera former av triangulering vilket redovisas nedan. Deltagande reflektioner av andra forskare och med forskningspersoner omfattar både att verifiera fynd och att reflektivt fördjupa och skapa rikare analyser.

\section{Uppdragsgivare}

I den fylliga beskrivningen av forskningen ingår att studie B var en del av det interdisciplinära forskningsprojektet Bridging the Gaps som länkade flera vetenskapliga discipliner och universitet som delade region Jönköpings län (RJL) som forskningspraktik. RJL har en lång tradition av systematiskt kvalitets- och förbättringsarbete och är med anledning av det nationellt och internationellt välkänd (Andersson-Gäre \& Neuhauser, 2007; Porter et al., 2011; Staines, Thor \& Robert, 2015). Syftet med Bridging the Gaps var att med vetenskapliga metoder studera ett antal hälso- och sjukvårdsenheter engagerade i att på olika sätt bidra till bättre vård genom kvalitets- och förbättringsarbete. Studierna inom projektets olika delprojekt skulle, förutom att bidra med ny kunskap, baseras på kliniska mikrosystem (Nelson, Batalden \& Godfrey 2007; Nelson, Batalden, Godfrey \& Lazar 2011) och genomföras med en interaktiv forskningsansats (Ellström 2008). Vårdenheten som ingick i detta avhandlingsarbete andra studie valdes i samarbete med projektets övergripande ledning. När forskning på det beskrivna sättet iscensätts av den verksamhet som skall studeras finns risk för att forskningsprocessen styrs av förväntningar på goda resultat. Detta motverkades genom att initialt och i samförstånd med vårdenhetens ledning fastställa att studien inte var en utvärderingsstudie, utan hade till syfte att öka kunskaperna om samspel och lärande i ett relativt nytt arbetssätt.

\section{Datainsamling och urval}

Data och vad eller vilka som förmedlar data ger forskningen en empirisk förankring.

I studie A har forskningspersonernas perspektiv och kunskaper fångats genom att använda olika former av intervjuer. Det var chefer i de respektive verksamheter som tillfrågade forskningspersonerna om att delta, vilket kunde innebära att urvalet präglades av extra motiverade och kompetenta personer. En chef valde tex. att själv delta, på grund av intresse. Samtidigt utgjorde den grupp som deltog ett strategiskt urval med spridning över verksamheter, ålder, kön (enbart läkargruppen), erfarenheter, positioner och de tre professionerna. Det överensstämmer med Carter et al. beskrivning av strategiskt urval för att få bredd i den data som samlas in (Carter et al., 2009). 
Genom att de tre intervjuarna tillhörde samma profession som forskningspersonerna de intervjuade, kunde språk och gemensam förståelse ge acceptans för intervjusituationen och bidra till uppriktiga beskrivningar. Samtidigt fanns risk för att fenomen togs för givna och inte uppmärksammades. Datainsamlingens grundlighet stärktes av att de individuella intervjuerna upprepades över tid tre gånger med en avslutande telefonintervju med samma forskningspersoner. De hade därigenom möjlighet att relatera erfarenheter i intervjuerna till sitt arbete och återkomma till det vid nästa intervjutillfälle.

Fokusgrupper med respektive profession och teamintervjuer hade en triangulerande och därmed validerande funktion i de individuella intervjuerna. Dessutom tillförde dialogerna mellan forskningspersoner från olika discipliner i respektive professioner att jämförelser ledde vidare till mer reflekterade beskrivningar.

Beslutet att i studie B tillämpa en interaktiv ansats skapade kongruens mellan forskningssyfte och forskningsstrategi, genom att studiet av samspel genomfördes genom samspel. Kombinationen med en fältstudiedesign där datainsamlingsmetoder både gav inifrånperspektiv och utifrånperspektiv har bidragit till att fånga helheten i de studerade praktikerna. Det utgjorde en triangulering utifrån olika former av data. Som etnografisk forskningsansats var observationstillfällena begränsade, men ändå så omfattande att medarbetarna blev familjära med min närvaro. Tracy menar att viktigast är att data ger möjlighet till och förkroppsligar meningsfulla och signifikanta påstående, inte tiden i fält (Tracy, 2010).

I gruppintervjuerna deltog vårdenhetens samtliga överläkare, medan undersköterskor och sjuksköterskor var utvalda av ledningsteamet. Om fler undersköterskor och sjuksköterskor deltagit i intervjuerna hade det möjligen gett ytterligare aspekter som kunnat bidra både i forskningsprocessen och för utvecklingen av rondandet på vårdavdelningen. De underläkare som hade arbetat på vårdavdelningen och vid intervjutillfället var i tjänst på kliniken valdes ut av klinikens studierektor. Intervjuer genomfördes inte med patienter, vilket hade gett ytterligare data om samspelet i ronderna. Etikansökan för studien var så formulerad att det inte fanns möjlighet att intervjua patienter.

Interaktiviteten skapade kreativa processer och initiativ från praktiken som bidrog till forskningsprocessen. Till exempel, i det förberedande fältarbetet växte det fram att det centrala studieobjektet skulle avgränsas till ronden. Det förberedande fältarbetet skapade förtroende och motivation både bland vårdenhetens medarbetare och för 
mig som forskare. De åkerkopplade preliminära fynden bidrog till engagemang hos vårdtagarna, men vid lärandeseminariet var inte alla deltagare så talföra, vilket kunde kompenseras. i gruppintervjuerna.

\section{Analyser}

De olika teoretiska perspektiven i delarbetena utgjorde en triangulering som visar att forskningen är rik och stödjer en bred förståelse, vilket stärker trovärdigheten

I delarbete I varvades individuella professionsspecifika och gemensamma analyser, vilket innebar en triangulering som bidrog till studiens validitet. I delarbete II, III och IV var i stället de induktiva analyserna tematiska och följde en given process. Den avslutande teoridrivna analysen var krävande och ställde krav på att jag som forskare var tillräckligt insatt i teorin, samtidigt som tillämpningen av teorin i analysprocessen fördjupade min förståelse. Upprepade genomgångar och diskussioner om framväxande teman och de idéer tolkningsprocessen skapade fördes med forskargruppen för att etablera konsensus i tolkningar och trovärdighet åt fynden. Dessutom bidrog det till att minska risken för att min relativa familjaritet med de studerade sammanhangen skulle skymma betydelsefulla fynd. Vid forskningsseminarier genomfördes också dataworkshops, vilket innebar att utdrag ur data från studierna analyserades i mindre grupper, med efterföljande gemensamma reflektioner. Denna triangulering, då olika observatörer gjorde analyser av samma rådata, både bekräftade mina analyser och tillförde nya perspektiv (Larsson, 2005). Genom dataworkshops stärktes transparens i analysen, vilket är i överensstämmelse med Polit och Becks rekommendationer (2008).

\section{Överförbarhet}

Med överförbarhet menas att fynd och slutsatser är potentiellt värdefulla eller användbara för flera sammanhang och situationer (Tracy, 2010). I kvalitativa studier syftar det inte på direkt överföring. I stället handlar det om läsares förståelse, igenkänning och överlappning av situationer. Både teoretiska och praktiska aspekter av studierna är möjliga att överföra till olika sammanhang. Fylliga beskrivningar och utformningen av texter och kompletterade illustrationer bidrar till överförbarheten. Fynd och slutsatser i avhandlingen har relevans i hälso- och sjukvårdens dagliga arbete utifrån flera av de beskrivna aspekterna. 


\section{KONKLUSIONER}

Lärande i det dagliga hälso- och sjukvårdsarbetet är nödvändigt för vårdens genomförande och utveckling, men hur det sker tas ofta för givet och utgör en tyst kunskap. Det här avhandlingsarbetet fokuserar på det komplexa lärande som utspelar sig i dagligt hälso- och sjukvårdsarbete, med särskilt fokus på läkare. Ambitionen har varit att inte avgränsa utan omfatta komplexiteten. Genom att tillämpa flera praktikteoretiska perspektiv i studier av reella hälso- och sjukvårdssammanhang, bidrar avhandlingen till fördjupade kunskaper om lärande och interaktion i hälso- och sjukvårdspraktiker.

Lärande och interaktion i hälso- och sjukvårdspraktiker har betydelse för ett flertal aspekter i hälso- och sjukvårdens genomförande såväl som dess beständighet (hållbarhet) och utveckling. Därför bidrar avhandlingen till dessa aspekter och synliggör också hur aspekterna förenas och ömsesidigt bidrar till varandras sammanhang.

Lärande i hälso- och sjukvårdspraktiker har relevans för patienter, deras närstående och deras delaktighet i utförandet av vården. Lärande är inbäddat i medicinskt, omvårdande och rehabiliterande arbete och har betydelse för vilket resultat arbetet leder till. I möten mellan olika professioner, discipliner eller andra samarbetspartner i det dagliga arbetet influerar lärande förståelse och samarbete. Grupper i hälso- och sjukvården som har specifika mål för lärandet och kompetensutveckling, som studenter, AT- och ST-läkare och medarbetare från andra länder. Också för dem som har uppdrag att handleda dessa grupper i hälso- och sjukvårdspraktiker har lärande och interaktion betydelse. Välfungerande lärande och interaktion i hälso- och sjukvårdspraktiker bidrar till hälsooch sjukvårdens kompetensförsörjning och vårdgivarnas livslånga lärande. När hälso- och sjukvårdens verksamheter tar initiativ för att genomföra förbättringar är lärande och interaktion mellan dem som deltar av central betydelse.

Dessa aspekter i hälso- och sjukvården samexisterar och studeras och utvecklas vanligen var för sig. Genom att avhandlingen fokuserar på hur lärande framträder där hälso- och sjukvården utförs knyts dessa aspekter samman. Därigenom fyller avhandlingen ett gap i kunskaper om hur lärande simultant har betydelse för flera grupper och funktioner i det dagliga arbetet. Frågan om vad som lärs eller behöver läras har däremot hållits i bakgrunden. 
Avhandlingen är förankrad i medicinsk pedagogisk forskningsparadigm. Genom ett sociomateriellt praktikteoretiskt perspektiv bidrar avhandlingen till fördjupade kunskaper om lärande och interaktion i hälso- och sjukvårdpraktiker. Här summeras vad avhandlingen bidrar med i förståelsen av lärande och interaktion med olika fokus i hälso- och sjukvårdspraktiker:

- Den pedagogiska dimensionen av vårdgivares patientarbete är inte synliggjord och vårdgivarna har sällan ett gemensamt språk eller strategier för hur de agerar.

- Vårdgivare agerar pedagogiskt med eller utan intention i mötet med patienter genom att avläsa (deras behov av att lära) - färdrikta (hur agera) - lärstödja (genom olika ageranden) när de utför sitt arbete. Pedagogiska processer är inbäddade i ett medicinskt, omvårdande eller rehabiliterande arbete.

- Genom att betrakta specifika vårdsammanhang som hälso- och sjukvårdspraktiker under utövning, framträder betydelsen av rummets iscensättning, deltagande personers sätt att agera och relatera till varandra och till redskap för lärande och interaktion.

- Lärande underlättas eller försvåras beroende på praktikarkitekturen, det vill säga utformningen av samspelet mellan personer, rumsliga och materiella förhållanden. Samskapande lärande ronder prefigureras av ömsesidigt utbyte mellan patienter, vårdgivare i flera professioner och redskap såsom informationsteknologi. Operativa ronder prefigureras av separata individuella arbetsprocesser och medför mer begränsat lärande.

- Läkare deltar i och växlar mellan flera hälso- och sjukvårdpraktiker. Denna mobilitet medför eget lärande och avsiktligt eller oavsiktligt stöd till andras lärande. Centralt både för lärande och lärstödjande är läkares arbete i individuella patienters processer genom vårdförloppen. Ansvarstagande och delande av olika perspektiv på utförande av arbete med patienter och med andra vårdgivare stimulerar lärande. 
- Underläkare utgör en grupp av vårdgivare som också är under utbildning och har i uppdrag att uppnå fastställda kompetenskrav i de hälso- och sjukvårdspraktiker där de deltar. Samspelet mellan hälso- och sjukvårdspraktikers arrangemang och genomförande snarare begränsar än underlättar lärande i underläkares lärandepraktiker. 


\section{IMPLIKATIONER}

\section{Lärande och interaktion i hälso- och sjukvårdpraktiker}

Hälso- och sjukvårdens verksamheter behöver skapa bra förutsättningar för patienter, deras närstående, studenter och vårdgivare i olika professioner, inklusive underläkare som har specifika mål för kompetensutveckling, att lära och utvecklas i dagligt kliniskt arbete. Nedan beskrivna implikationer av avhandlingens fynd och diskussioner är angelägna budskap till verksamheter där läkare, andra vårdgivare och patienter interagerar, såväl som till deras ledningar och övergripande ledningssystem.

För att lärande i dagligt hälso- och arbete ska bli mer än enkel överföring av kunskap visar avhandlingens fynd i överenstämmelse med Ellström et al. (E. Ellström, Ekholm, \& Ellström, 2008), att arbetsplatserna behöver designas så att lärande stimuleras. Vårdgivare behöver vara kunniga att läsa av och använda sig av möjligheter till lärande och lärstödjande agerande. Genom att synliggöra förutsättningarna i det komplexa lärande som ständigt pågår i dagligt hälso- och sjukvårdarbete, kan dessa också förändras så att enskilda deltagare blir kunnigare och säkrare. Det kan innefatta såväl patientarbete som handledningsuppdrag.

I anslutning till specifika arbetssituationer kan "rum" skapas för att resonera om pedagogiska dimensioner i det arbete som just utförs eller har utförts, såväl inom och som mellan professioner. Sådant resonerande utfört gemensamt i flödet av dagligt arbete med fokus på arbetets genomförande och knyter samman arbete och lärande i det som Boud beskriver som produktiv reflektion (Boud, 2010; Boud, Cressey, \& Docherty, 2006).

För att underläkare ska kunna utveckla den bredd av medicinskt och generiskt kunnande som de behöver som specialister och som målbeskrivningarna kräver, behöver de kontinuitet, koherens och balanserad progresson av uppgifter och ansvar i sitt kliniska arbete. För att uppnå det behöver underläkarnas lärandepraktiker synliggöras, integreras och utvecklas till en naturlig del i varje enskild vårdverksamhet, det vill säga hur arbetsplatsen utformar och fördelar arbete. Däri behöver speciellt beaktas betydelsen av underläkares arbete med patienter i deras processer genom vårdförloppen, deras 
ansvarstagande och roterande mellan olika vårdenheter och verksamheter.

Om hälso- och sjukvårdens verksamheter och dess ledare inte uppmärksammar att underläkarnas lärandepraktiker riskerar att marginaliseras, kan det förutom sämre lärande för underläkare också medföra felaktig användning av resurser och dåligt utnyttjad arbetskraft.

Utifrån patientlagen (SFS 2014:821) och olika initiativ för att utveckla personcentrerad och samskapad hälso- och sjukvård, kan kunskap om lärande i hälso- och sjukvårdspraktiker vara ett tillskott. Konkret kan det handla om ronder, behandlingskonferenser, mottagningsverksamhet eller specifika behandlingsenheter. Att vårdgivarna i dessa sammanhang får kunskap om och erfarenhet av hur både sociala och materiella förhållanden formar arbetet och det lärande som framträder däri. Därigenom möjliggörs att lärande och samskapande stärker och potentierar varandra i deltagarnas gemensamma arbetsuppgifter. Vården har möjlighet att utvecklas genom samskapande och kollektivt lärande, samtidigt som patienter och vårdgivare utvecklar sitt kunnande utifrån deras specifika behov och uppdrag.

När samskapande lärande hälso- och sjukvårdspraktiker utvecklas bör de arrangeras så att vårdgivare som är nya, tillfälliga och noviser involveras, kan ställa frågor och bidra med sina perspektiv. Om det inte sker riskerar situationer uppstå där dessa grupper eller deras behov marginaliseras.

Väl utvecklade samskapande hälso- och sjukvårdspraktiker ser jag som potentiella sammanhang för att ständigt förbättra utförandet av vården. Kvalitets- och förbättringsarbete integrerat i dagliga arbetsuppgifter med praktikarkitekturer som redskap för förbättringar. Genom att beakta alla arrangemang i praktikarkitekturer menar Kemmis att förutsättningar för varaktiga och genomgripande förändringar ökar (Kemmis \& Mutton, 2012). Därigenom ökar också möjligheterna att knyta samman specifika hälso- och sjukvårdspraktiker, med dess lärande och utveckling. Det har också implikationer på hur enskilda vårdgivare med sina hälso- och sjukvårdspraktiker omsätter de kunskapsstöd som utvecklats nationellt i praktisk kliniskt arbete.

Hälso- och sjukvårdens övergripande ledningar och ledningar i enskilda verksamheter har betydelse för hur "rum" för lärande i kliniskt arbete har möjlighet att utvecklas. I ledningars strategier för vårdens kvalitet och 
säkerhet med ökad involvering av patienter, för vårdgivares kompetensutveckling, utbildningsuppdrag avseende underläkare och studenter och långsiktiga kompetensförsörjning kan synliggörandet av lärande $\mathrm{i}$ och inte bredvid dagligt kliniskt arbete vara positivt förstärkande. Om dessa aspekter uppfattas som eller är konkurrerande i vårdens verksamheter, kan formande av förutsättningar för lärande såsom beskrivits $\mathrm{i}$ avhandlingen istället utveckla gemensamma helheter. Möjligen med vinster också för arbetsmiljö, attraktivitet och rekrytering.

En innovativ långsiktig målsättning för hälso- och sjukvården borde vara att hälso- och sjukvårdens utbildande uppdrag integreras, studeras och följs upp i varje verksamhets verksamhetsplaner på motsvarande sätt som det patientrelaterade uppdraget.

\section{Fortsatt forskning}

Fortsatt forskning om lärande och interaktion i hälso- och sjukvårdspraktiker skulle kunna tillämpa sociomateriella praktikteoretiska perspektiv i studier av andra specifika hälso-och sjukvårdspraktiker, fokusera på andra professioner, inkludera studenter eller vårdgivare med utbildning i andra länder.

Det behövs vidare studier av ronder i olika verksamheter som kan bekräfta förekomsten av och förutsättningar för att varaktigt etablera samskapande lärande ronder.

Med fältstudier och interaktiv forskningsansats vore det intressant att studera hur vårdgivares kunskapssyn och agerande i pedagogiska processer påverkas genom moment av produktiv reflektion i dagligt kliniskt arbete

Med interaktiva forskningsansatser kan man utveckla och tillämpa praktikarkitekturer för att kunna synliggöra och utveckla enskilda vårdenheters fungerande. Det kan relateras både till samskapande med patienter, interprofessionellt samarbete, underläkares och/eller studenters lärande som ett redskap i kvalitets- och utvecklingsarbete.

Med anledning av de omfattning administrativa uppgifter läkare och andra vårdgivare har, är fördjupade studier av samspel mellan informationsteknologi, vårdgivare och vårdtagare angeläget.

Fortsatt praktikorienterad forskning behövs för att öka kunskapen och tillämpningar av underläkares lärandepraktiker. I verksamheter inom 
flera discipliner kan man identifiera, jämföra och utveckla underläkares lärandepraktiker.

Både helheten av och enskilda teman som i avhandlingen indikerar betydelsen av att stimulera lärande i dagligt arbete behöver mer ingående studeras. Temana omfattar i hälso- och sjukvårdspraktiker är nya, tillfälliga eller novisa deltagare, problem som inte har självklara lösningar, osäkerhet och oväntade situationer, relationella spänningar när olika perspektiv möts, relationella spänningar i ansvarstagande och läkares mobilitet.

I pågående forskning om samskapande hälso- och sjukvård med stöd av avhandlingens fynd inkludera aspekter om lärande i dagligt arbete.

Intresset för livslångt lärande har ökat och sociomateriellt praktikteoretiskt grundade studier bör kunna tillföra fördjupade kunskaper och handlingsmönster. 


\section{REFERENSER}

Aagaard Nielsen, K., \& Svensson, L. (2006). Action and interactive research : beyond practice and theory. Maastricht: Shaker Publishing.

Andersson-Gäre, B., \& Neuhauser, D. (2007). The health care quality journey of Jonkoping County Council, Sweden. Quality Management in Health Care, 16(1), 2-9.

Bastjänstgöring för läkare. (2017). [Stockholm]: Regeringskansliet, Socialdepartementet.

Batalden, M., Batalden, P., Margolis, P., Seid, M., Armstrong, G., OpipariArrigan, L., \& Hartung, H. (2016). Coproduction of healthcare service. BMJ Quality \& Safety, 25(7), 509-517. doi: 10.1136/bmjqs2015-004315

Batalden, P., \& Davidoff, F. (2007). What is "quality improvement" and how can it transform healthcare? Quality and Saftey in Health Care, 16(1), 2-3.

Beckett, D., \& Hager, P. (2000). Making judgments as the basis for workplace learning: towards an epistemology of practice. International Journal of Lifelong Education, 19(4), 300-311. doi: 10.1080/02601370050110365

Billett, S. (2016). Learning through health care work: premises, contributions and practices. Medical Education, 5O(1), 124-131. doi: 10.1111/medu.12848

Boud, D. (2010). Relocating reflection in the context of practice. Australia, Australia/Oceania: Routledge.

Boud, D., Cressey, P., \& Docherty, P. (2006). Productive reflection at work: Learning for changing organizations: Routledge.

Bruce, C. R., Miller, S. M., \& Zimmerman, J. L. (2015). A qualitative study exploring moral distress in the ICU team: The importance of unit functionality and intrateam dynamics. Critical Care Medicine, 43(4), 823-831. doi: 10.1097/CCM.0000000000000822

Brudney, J. L., \& England, R. E. (1983). Toward a Definition of the Coproduction Concept. Public Administration Review, 43(1)(1), 5965. doi: $10.2307 / 975300$

Bunniss, S., \& Kelly, D. R. (2010). Research paradigms in medical education research. Medical Education, 44(4), 358-366.

Bååthe, F., \& Norbäck, L. E. (2013). Engaging physicians in organisational improvement work. Journal of Health Organization and Management, 27(4), 479-497. doi: doi:10.1108/JHOM-02-20120043 
Carlfjord, S., \& Festin, K. (2014). Primary health care staff's opinions about changing routines in practice: a cross-sectional study. BioMed Family Practice, 15(1), 2-15. doi: 10.1186/1471-2296-15-2

Carraccio, C., Wolfsthal, S. D., Englander, R., Ferentz, K., \& Martin, C. (2002). Shifting Paradigms: From Flexner to Competencies. Academic Medicine, 77(5), 361-367.

Carter, S. M., Ritchie, J. E., \& Sainsbury, P. (2009). Doing good qualitative research in public health: not as easy as it looks. N S W Public Health Bulletin, 20(7-8):105-11.

Cooke, M., Irby, D. M., \& O'Brien, B. C. (2010). Educating physicians: a call for reform of medical school and residency (Vol. 16): John Wiley \& Sons.

Croker, A., Brown, L., Little, A., \& Crowley, E. (2016). Interprofessional relationships for work-integrated learning in healthcare: identifying scope for ongoing professional development. Creative Education, $7(1), 1729-1738$.

Dixon-Woods, M., McNicol, S., \& Martin, G. (2012). Ten challenges in improving quality in healthcare: lessons from the Health Foundation's programme evaluations and relevant literature. $B M J$ Quality \& Safety, 21(10), 876-884.

Dorman, T., \& Miller, B. M. (2011). Continuing medical education: the link between physician learning and health care outcomes. Academic Medicine, 86(11). doi: 10.1097/ACM.obo13e3182308d49

Dunston, R. (2014). Arrangements of co-production in healthcare. In T. J. Fenwock \& M. Nerland (Eds.), Reconceptualising Professional Learning: Sociomaterial Knowledges, Practices and Responsibilities (pp. 140-152). New York: Routledge.

Dunston, R., Lee, A., Boud, D., Brodie, P., \& Chiarella, M. (2009). CoProduction and Health System Reform - From Re-Imagining To Re-Making. The Australian Journal of Public Administration, 68(1), 39-52. doi: 10.1111/j.1467-8500.2008.00608.x

Dyrbye, L., \& Shanafelt, T. (2016). A narrative review on burnout experienced by medical students and residents. Medical Education, 5O(1), 132-149. doi: 10.1111/medu.12927

Ekman, I., Swedberg, K., Taft, C., Lindseth, A., Norberg, A., Brink, E., .. . Kjellgren, K. (2011). Person-centered care-Ready for prime time. European journal of cardiovascular nursing, 10(4), 248-251.

Ellström, E., Ekholm, B., \& Ellström, P. E. (2008). Two types of learning environment: Enabling and constraining a study of care work. Journal of Workplace Learning, 2O(2), 84-97. doi: doi:10.1108/13665620810852250

Ellström, P. E. (2008). Knowledge creation through interactive research: A learning approach. Paper presented at the Proceedings of the ECER Conference.

Engebretsen, E., Heggen, K., Wieringa, S., \& Greenhalgh, T. (2016).

Uncertainty and objectivity in clinical decision making: a clinical 
case in emergency medicine. Medicine, Health Care and Philosophy, 19(4), 595-603. doi: 10.1007/s11019-016-9714-5

Fang, C., Lee, J., \& Schilling, M. A. (2010). Balancing exploration and exploitation through structural design: The isolation of subgroups and organizational learning. Organization Science, 21(3), 625-642.

Fenwick, T. (2008). Understanding relations of individual-collective learning in work: A review of research. Management Learning, 39(3), 227-243. doi: 10.1177/1350507608090875

Fenwick, T. (2008). Workplace learning: Emerging trends and new perspectives. New directions for adult and continuing education, 2008(119), 17-26.

Fenwick, T. (2010). Re-Thinking the "Thing" Sociomaterial Approaches to Understanding and Researching Learning in Work. Journal of Workplace Learning, 22(1-2), 104-116.

Fenwick, T., Edwards, R., \& Sawchuk, P. (2011). Emerging approaches to educational research: tracing the sociomaterial. Abingdon, England: Routledge, Taylor and Francis.

Foley, T. J., \& Vale, L. (2017). What role for learning health systems in quality improvement within healthcare providers? Learning Health Systems, 1(4), e10025-n/a. doi: 10.1002/lrh2.10025

Folkhälsans utveckling - årsrapport 2017 [Elektronisk resurs]. (2017). Folkhälsomyndigheten. Hämtad från https://www.folkhalsomyndigheten.se/contentassets/9de83d1af6c e4a429e833d3c8d7ccf85/folkhalsans-utveckling-arsrapport-201716136-webb2.pdf

Francisco, S., Mahon, K., \& Kemmis, S. (2017a). Transforming Education and Professional Practice. In K. Mahon, S. Francisco, \& K. S. (Eds.), Exploring Education and Professional Practice (pp. 257-264). Singapore: Springer.

Francisco, S., Mahon, K., \& Kemmis, S. (2017b). Transforming Education and Professional Practice. Exploring Education \& Professional Practice, 257.

Frank, J. R., Snell, L. S., Cate, O. T., Holmboe, E. S., Carraccio, C., Swing, S. R., . . . Harris, K. A. (2010). Competency-based medical education: theory to practice. Medical Teacher, 32(8), 638-645. doi: 10.3109/0142159X.2010.501190

Frenk, J., Chen, L., Bhutta, Z. A., Cohen, J., Crisp, N., Evans, T., .. . Zurayk, H. (2010). Health professionals for a new century: transforming education to strengthen health systems in an interdependent world. Lancet, 376(9756), 1923-1958. doi: 10.1016/So140-6736(10)61854-5

Friedberg, M. W., Chen, P. G., Van Busum, K. R., Aunon, F., Pham, C., Caloyeras, J., .. . Tutty, M. (2014). Factors Affecting Physician Professional Satisfaction and Their Implications for Patient Care, Health Systems, and Health Policy. Rand Health Quarterly, 3(4), 1. 
Gherardi, S. (2012). Why do practices change and why do they persist? Models of explanations Practice, Learning and Change (pp. 217231): Springer.

Gherardi, S. (2014). Rethinking materiality and border resources in telemedicine. In T. Fenwick, Nerland M. (Ed.), Reconceptualising Professional Learning: Sociomaterial Knowledges, Practices and Responsibilities (pp. 11-24). New York: Routledge.

Glaser, B. (2017). Discovery of grounded theory: Strategies for qualitative research: Routledge.

Green, B. (2009). Understanding and researching professional practice Rotterdam: Sense Publishers.

Greenhalgh, T., Howick, J., \& Maskrey, N. (2014). Evidence based medicine: a movement in crisis? , 348. doi: 10.1136/bmj.g3725

Greenhalgh, T., Raftery, J., Hanney, S., \& Glover, M. (2016). Research impact: a narrative review. BMC medicine, 14(1), 78 .

Hamet, P., \& Tremblay, J. (2017). Artificial intelligence in medicine. Metabolism: Clinical and Experimental, 69, S36-S40. doi: 10.1016/j.metabol.2017.01.011

Hammersley, M. (2006). Ethnography: problems and prospects. Ethnography and Education, 1(1), 3-14.

Hammersley, M. (2018). What is ethnography? Can it survive? Should it? Ethnography and Education, 13(1), 1-17. doi: 10.1080/17457823.2017.1298458

Hawkins, R. E., Welcher, C. M., Holmboe, E. S., Kirk, L. M., Norcini, J. J., Simons, K. B., \& Skochelak, S. E. (2015). Implementation of competency-based medical education: are we addressing the concerns and challenges? Medical Education, 49(11), 1086-1102.

Headrick, L. A., Ogrinc, G., Hoffman, K. G., Stevenson, K. M., Shalaby, M., Beard, A. S., . . . Baum, K. D. (2016). Exemplary care and learning sites: A model for achieving continual improvement in care and learning in the clinical setting. Academic Medicine, 91(3), 354359. doi: 10.1097/ACM.0000000000001072

Hodges, B. D., \& Kuper, A. (2012). Theory and practice in the design and conduct of graduate medical education. Academic Medicine, 87(1), 25-33.

Hopwood, N. (2014). Four Essential Dimensions of Workplace Learning. Journal of Workplace Learning, 26(6-7), 349-363.

Hopwood, N., Day, C., \& Edwards, A. (2016). Partnership practice as collaborative knowledge work: overcoming common dilemmas through an augmented view of professional expertise. Journal of Children's Services, 11(2), 111-123.

Hopwood, N., Fowler, C., Lee, A., Rossiter, C., \& Bigsby, M. (2013). Understanding partnership practice in child and family nursing through the concept of practice architectures. Nursing Inquiry, 2O(3), 199-210. 
Hunt, L. M., Bell, H. S., Baker, A. M., \& Howard, H. A. (2017). Electronic Health Records and the Disappearing Patient. Medical anthropology quarterly, 31(3), 403-421.

Jacobsson, G., Lindahl, B., \& Nordin, A. (2015). Nationella kvalitetsregister $i$ hälso-och sjukvården. Stockholm : Karolinska Institutet University Press.

Jakobsson, S., Jakobsson Ung, E., Lindström, M., Ringström, G., \& Eliasson, B. (2018). Health status and most distressing concerns at admission and discharge reported by patients cared for at an internal medical care ward. Scandinavian Journal of Caring Sciences. doi: 10.1111/scs.12562

Kemmis, S. (2011). What is professional practice? Recognising and respecting diversity in understandings of practice. In C. Kanes (Ed.), Elaborating Professionalism (Vol. 5, pp. 139-165). Dordrecht: Springer Netherlands.

Kemmis, S. (2014). Praxis, Practice and Practice Architectures. In W. J. Kemmis S., Edwards-Groves C., Hardy I., Grootenboer P., Bristol L. (Ed.), Changing Practices, Changing Education (pp. 25-41). Singapore: Springer.

Kemmis, S., Edwards-Groves, C., Wilkinson, J., \& Hardy, I. (2012). Ecologies of practices. In P. Hager, A. Lee, \& A. Reich (Eds.), Practice, learning and change (pp. 33-49): Springer.

Kemmis, S., \& Mahon, K. (2017). Coming to 'practice architectures': A genealogy of the theory. In K. Mahon, S. Francisco \& S. Kemmis (Eds.), Exploring Education and Professional Practice (pp. 219238). Netherlands Dordrecht: Springer.

Kemmis, S., \& Mutton, R. (2012). Education for sustainability (EfS): practice and practice architectures. Environmental Education Research, 18(2), 187-207. doi: 10.1080/13504622.2011.596929

Kemmis, S., Wilkinson, J., Edwards-Groves, C., Hardy, I., Grootenboer, P., \& Bristol, L. (2013). Changing practices, changing education. Singapore: Springer

Kemmis, S., Wilkinson, J., Edwards-Groves, C., Hardy, I., Grootenboer, P., \& Bristol, L. (2014). Ecologies of Practices Changing Practices, Changing Education (pp. 43-54). Singapore: Springer.

Kennedy, T. J., \& Lingard, L. A. (2006). Making sense of grounded theory in medical education. Medical Education, 4O(2), 101-108.

Kerno, S. J., \& Mace, S. L. (2010). Communities of Practice: Beyond Teams. Advances in Developing Human Resources, 12(1), 78-92. doi: 10.1177/1523422310365341

Kilminster, S. (2010). Understanding the nature and purpose of clinical and educational supervision. InnovAiT, 3(10), 615-618.

Kilminster, S., Zukas, M., Quinton, N., \& Roberts, T. (2010). Learning practice? Exploring the links between transitions and medical performance. Journal of Health Organization and Management, 24(6), 556-570. doi: doi:10.1108/14777261011088656 
Kirkegaard, S., \& Andersen, D. (2018). Co-production in community mental health services: blurred boundaries or a game of pretend? Sociology of Health \& Illness. doi: 10.1111/1467-9566.12722

Kulaylat, A. N., Qin, D., Sun, S. X., Hollenbeak, C. S., Schubart, J. R., Aboud, A. J., . . Han, D. C. (2017). Perceptions of mistreatment among trainees vary at different stages of clinical training. $B M C$ Medical Education, 17(1), 14. doi: 10.1186/s12909-016-0853-4

Larsson, S. (2005). Om kvalitet i kvalitativa studier. Nordisk pedagogik, 25(1), 16-35.

Lattuca, L. R. (2002). Learning Interdisciplinarity: Sociocultural Perspectives on Academic Work. The Journal of Higher Education(6), 711.

Lave, J., \& Wenger, E. (1991). Situated learning: legitimate peripheral participation. Cambridge: Cambridge University Press.

Likosky, D. S. (2014). Clinical Microsystems: A Critical Framework for Crossing the Quality Chasm. 46(1), 33-37.

Lindgren, S., \& Gordon, D. (2011). The doctor we are educating for a future global role in health care. Medical Teacher, 33(7), 551-554. doi: 10.3109/0142159X.2011.578174

Läkarutbildningsutredningen. (2013). För framtidens hälsa - en ny läkarutbildning : betänkande. Stockholm: Fritze.

Mahon, K., Kemmis, S., Francisco, S., \& Lloyd, A. (2017). Introduction: Practice theory and the theory of practice architectures. In K. Mahon, Francisco, Susanne. \& Kemmis, Stephen. (red.) (Ed.), Exploring Education and Professional Practice (pp. 1-30). Singapore: Springer Singapore.

Malterud, K. (2001). Qualitative research: standards, challenges, and guidelines. Lancet, 358(9280), 483-488.

Mann, K. V. (2011). Theoretical perspectives in medical education: past experience and future possibilities. Medical Education, 45(1), 6068.

Marcum, J. A. (2008). An Introductory Philosophy of medicine: Humanizing Modern Medicine. Dordrecht : Springer.

Mertens, F., de Groot, E., Meijer, L., Wens, J., Gemma Cherry, M., Deveugele, M., . . Pype, P. (2018). Workplace learning through collaboration in primary healthcare: A BEME realist review of what works, for whom and in what circumstances: BEME Guide No. 46.

Medical Teacher, 4O(2), 117-134. doi: 10.1080/0142159X.2017.1390216

Mikkonen, I., \& Hynynen, M. A. (2012). Health care professionals' views about supporting patients' self-management. Health Education(5), 396. doi: 10.1108/09654281211253416

Nelson, E., Batalden, P., \& Godfrey, M. (2007). Quality by design: a clinical microsystems approach. Jossy-Bass, San Francisco.

Nicolini, D. (2009). Zooming in and out: Studying practices by switching theoretical lenses and trailing connections. Organization Studies, 3O(12), 1391-1418. 
Nicolini, D. (2011). Practice as the Site of Knowing: Insights from the Field of Telemedicine. Organization Science, 22(3), 602-620. doi: 10.1287/orsc.1100.0556

Nicolini, D. (2014). Practice Theory, Work, and Organization : An Introduction. Oxford: Oxford University Press.

Nicolini, D. (2016). Is small the only beautiful? Making sense of'large phenomena'from a practise-based perspective. In A. Hui, (editor.), T. R. Schatzki, (editor.) , \& E. Shove, (editor.) (Eds.), The nexus of practices : connections, constellations and practitioners London: Routledge, 2016.

Nicolini, D., \& Monteiro, P. (2016). The practice approach: for a praxeology of organisational and management studies. In A. Langley \& H. Tsoukas (Eds.), The SAGE handbook of process organization studies [Elektronisk resurs] London: SAGE.

Norman, G., Norcini, J., \& Bordage, G. (2014). Competency-Based Education: Milestones or Millstones? Journal of Graduate Medical Education, 6(1), 1-6. doi: 10.4300/jgme-d-13-00445.1

Nyström, M., Sparring, V., Granström, E., Andreen Sachs, M., Hvitfeldt, H., Hansson, J., . . ., \& Brommels, M. (2017). Nationella kvalitetsregistersatsningen 2012-2016.. Forskningsrapport. Hämtad 11 april, 2018, från http://kvalitetsregister.se/download/18.36f51e3d161942980eed851 6/1519298517010/Nationella_Kvalitetsregistersatsningen_2012_2 016_september_2017.pdf

Ostrom, E. (1996). Crossing the great divide: coproduction, synergy, and development. World Development, 24(6), 1073-1087.

Parent, F., Jouquan, J., \& De Ketele, J.-M. (2013). CanMEDS and other "competency and outcome-based approaches" in medical education: clarifying the ongoing ambiguity. Advances in Health Sciences Education, 18(1), 115-122.

Pétré, B., Gagnayre, R., De Andrade, V., Ziegler, O., \& Guillaume, M. (2017). From therapeutic patient education principles to educative attitude: the perceptions of health care professionals-a pragmatic approach for defining competencies and resources. Patient Preference and Adherence, 11, 603.

Polanyi, M. (2009). The tacit dimension. Chicago: University of Chicago press.

Polit, D. F., \& Beck, C. T. (2008). Nursing research : generating and assessing evidence for nursing practice. Philadelphia: Wolters Kluwer Health/Lippincott Williams \& Wilkins.

Porter, Michael E. and Baron, Jennifer F. and Rejler, Martin. (2011). Highland District County Hospital: Gastroenterology Care in Sweden (October 13, 2011). Harvard Business School Strategy Unit Case No. 710-469. Hämtad 12 april, 2018, från : https://ssrn.com/abstract $=2041303$ 
Reckwitz, A. (2002). Toward a theory of social practices: a development in culturalist theorizing. European Journal of Social Theory, 5(2), 243-263.

Rees, C. E., \& Monrouxe, L. V. (2010). Theory in medical education research: how do we get there? Medical Education, 44(4), 334-339.

Reeves, S., Goldman, J., Gilbert, J., Tepper, J., Silver, I., Suter, E., \& Zwarenstein, M. (2011). A scoping review to improve conceptual clarity of interprofessional interventions. Journal of Interprofessional Care, 25(3), 167-174. doi: $10.3109 / 13561820.2010 .529960$

Reich, A. (2012). Disciplined doctors: The electronic medical record and physicians' changing relationship to medical knowledge. Social Science \& Medicine, 74, 1021-1028. doi: 10.1016/j.socscimed.2011.12.032

Reich, A., \& Hager, P. (2014). Problematising practice, learning and change: practice-theory perspectives on professional learning. Journal of Workplace Learning, 26(6/7), 418-431. doi: 10.1108/JWL-02-2014-0016

Rejler, M., Spangeus, A., Tholstrup, J., \& Andersson-Gare, B. (2007). Improved population-based care: Implementing patient-and demand-directed care for inflammatory bowel disease and evaluating the redesign with a population-based registry. Qual Manag Health Care, 16(1), 38-50.

Rejler, M., Tholstrup, J., Elg, M., Spångéus, A., \& Gäre, B. A. (2012). Framework for assessing quality of care for inflammatory bowel disease in Sweden. World Journal of Gastroenterology: WJG, 18(10), 1085 .

Richards, T., Montori, V., M. , Godlee, F., Lapsley, P., \& Paul, D. (2013). Let the patient revolution begin: Patients can improve healthcare: it's time to take partnership seriously. BMJ: British Medical Journal(7908), 7.

Rocco, P. (2016). Contextualizing co-production of health care: a systematic literature review. International Journal of Public Sector Management, 29(1), 72-90. doi: doi:10.1108/IJPSM-07-2015-0125

Sachdeva, A. K. (2016). Continuing Professional Development in the Twenty-First Century. Journal of Continuing Education in the Health Professions, 36, S8.

Schatzki, T. R. (2002). The site of the social: a philosophical account of the constitution of social life and change. University Park, Pa.: Pennsylvania State University Press.

Schön, D. A. (1987). Educating the reflective practitioner: [toward a new design for teaching and learning in the professions]. San Francisco: Jossey-Bass.

Schön, D. A. (2017). The reflective practitioner: How professionals think in action: London: Routledge.

SFS 2014:821. Patientlagen. [Elektronisk resurs] Stockholm:

Socialdepartementet. Hämtad 12 april, 2018, 
frånhttps://www.riksdagen.se/sv/dokumentlagar/dokument/svensk-forfattningssamling/patientlag2014821_sfs-2014-821

SOSFS 2015:8. Socialstyrelsens föreskrifter och allmänna råd om läkarnas specialiseringstjänstgöring. Hämtad 9 april, 2018, from https://www.socialstyrelsen.se/publikationer2015/2015-3-1

SOU 2016:2. Effektiv vård: slutbetänkande. Hämtad 12 april, 2018 från http://www.sou.gov.se/wp-content/uploads/2016/o1/SOU2016_2_Hela4.pdf

Shanafelt, T. D., Hasan, O., Dyrbye, L. N., Sinsky, C., Satele, D., Sloan, J., \& West, C. P. (2015). Changes in Burnout and Satisfaction With Work-Life Balance in Physicians and the General US Working Population Between 2011 and 2014. Mayo Clinics Proceedings, 9o(12), 1600-1613. doi: 10.1016/j.mayocp.2015.08.023

Sheu, L., O'Sullivan, P. S., Aagaard, E. M., Tad-Y, D., Harrell, H. E., Kogan, J. R., . . Hauer, K. E. (2016). How Residents Develop Trust in Interns: A Multi-Institutional Mixed-Methods Study. Academic Medicine: Journal Of The Association Of American Medical Colleges, 91(10), 1406-1415.

Sinsky, C., Colligan, L., Li, L., Prgomet, M., Reynolds, S., Goeders, L., . . . Blike, G. (2016). Allocation of physician time in ambulatory practice: a time and motion study in 4 specialties. Annals of Internal Medicine, 165(11), 753-760.

SKL (2017). Samverkan för kunskapsstyrning i vård och omsorg hämtad 9 april, 2018 från

https://skl.se/halsasjukvard/kunskapsstodvardochbehandling/syst emforkunskapsstyrning/nationellaprogramomraden/samverkanfor kunskapsstyrning.9686.html

Srivastava, P., \& Hopwood, N. (2009). A practical iterative framework for qualitative data analysis. International Journal of Qualitative Methods, 8(1), 76-84.

Spilg, E., Siebert, S., \& Martin, G. (2012). A social learning perspective on the development of doctors in the UK National Health Service.

Social Science \& Medicine, 75(9), 1617-1624. doi: 10.1016/j.socscimed.2012.06.014

Staines, A., Thor, J., \& Robert, G. (2015). Sustaining Improvement? The 20-Year Jönköping Quality Improvement Program Revisited. Quality management in health care, 24(1), 21-37. doi: 10.1097/qmh.0000000000000048

Strand, P., Edgren, G., Borna, P., Lindgren, S., Wichmann-Hansen, G., \& Stalmeijer, R. E. (2014). Conceptions of how a learning or teaching curriculum, workplace culture and agency of individuals shape medical student learning and supervisory practices in the clinical workplace. Advances in Health Sciences Education : Theory and Practice.. doi: 10.1007/s10459-014-9546-0

Strand, P., Edgren, G., Borna, P., Lindgren, S., Wichmann-Hansen, G., \& Stalmeijer, R. E. (2015). Conceptions of how a learning or teaching 
curriculum, workplace culture and agency of individuals shape medical student learning and supervisory practices in the clinical workplace. Advances in Health Sciences Education, 20(2), 531-557. doi: 10.1007/s10459-014-9546-o

Stroud, L., Oulanova, O., Szecket, N., \& Ginsburg, S. (2012). “The Benefits Make Up for Whatever Is Lost": Altruism and Accountability in a New Call System. Academic Medicine, 87(10), 1421-1427. doi: 10.1097/ACM.obo13e31826768d4

Subramony, A., Hametz, P. A., \& Balmer, D. (2014). Family-centered rounds in theory and practice: an ethnographic case study. Academic Pediatrics, 14(2), 200-206. doi: 10.1016/j.acap.2013.11.003

Suchman, L. (1995). Making Work Visible. Communications of the ACM, 38(9), 56-64. doi: 10.1145/223248.223263

Swenne, C. L., \& Skytt, B. (2014). The ward round - patient experiences and barriers to participation. Scandinavian Journal of Caring Sciences, 28(2), 297-304. doi: 10.1111/scs.12059.

Thörne, K., Andersson-Gäre, B., Hult, H., \& Abrandt-Dahlgren, M. (2017). Co-Producing Interprofessional Round Work: Designing Spaces for Patient Partnership. Quality Management in Healthcare, 26(2), 70-82. doi: 10.1097/qmh.0000000000000133

Tracy, S. J. (2010). Qualitative quality: Eight "big-tent" criteria for excellent qualitative research. Qualitative Inquiry, 16(10), 837-851.

Van de Ven, A. H., \& Johnson, P. E. (2006). Knowledge for theory and practice. Academy of Management Review, 31(4), 802-821.

Wass, S., Vimarlund, V., \& Ros, A. (2017). Exploring patients' perceptions of accessing electronic health records: Innovation in healthcare. Health Informatics Journal, 1460458217704258.

Wearne, S. M., Dornan, T., Teunissen, P. W., \& Skinner, T. (2015). Supervisor Continuity or Co-Location: Which Matters in Residency Education? Findings From a Qualitative Study of Remote Supervisor Family Physicians in Australia and Canada. Academic Medicine, 9o(4), 525-531. doi: 10.1097/acm.0000000000000587

Wenger, E. (1998). Communities of practice: Learning as a social system. Systems Thinker, 9(5), 2-3.

Wenger, E., McDermott, R. A., \& Snyder, W. (2002). Cultivating communities of practice: a guide to managing knowledge. Boston: Harvard Business School Press.

Vestergaard, E., \& Nørgaard, B. (2018). Interprofessional collaboration: An exploration of possible prerequisites for successful implementation. Journal of Interprofessional Care, 32(2), 185-195. doi: 10.1080/13561820.2017.1363725

Wolf, A., Ekman, I., \& Dellenborg, L. (2012). Everyday practices at the medical ward: a 16-month ethnographic field study. BMC Health Services Research, 12(1), 184.

Vygotskij, L. S., Hanfmann, E., Vakar, G., \& Kozulin, A. (2012). Thought and language. Cambridge, Mass.: MIT Press. 
Åhgren, B. (2010). Dissolving the Patient Bermuda Triangle. International Journal of Care Coordination(4), 137. doi: 10.1258/jicp.2010.010025

Östgötakommissionen för folkhälsa : slutrapport. (2014). Linköping: Östgötakommissionen för jämlik hälsa. 


\section{Papers}

The papers associated with this thesis have been removed for copyright reasons. For more details about these see:

http://urn.kb.se/resolve?urn=urn:nbn:se:liu:diva-147359 